SANDIA REPORT

SAND96-2001 • UC-600

Unlimited Release

Printed August 1996
RECENDOD

OCT 231936

OSTI

\title{
Technology Integration Project: Environmental Restoration Technologies Department Sandia National Laboratories
}

Cecelia V. Williams, Thomas D. Burford, Cheryl Ann Allen

Prepared by

Sandia National Laboratories

Albuquerque, New Mexico 87185 and Livermore, California 94550

for the United States Department of Energy

under Contract DE-AC04-94AL85000

Approved for public release; distribution is unlimited. 
Issued by Sandia National Laboratories, operated for the United States Department of Energy by Sandia Corporation.

NOTICE: This report was prepared as an account of work sponsored by an agency of the United States Government. Neither the United States Government nor any agency thereof, nor any of their employees, nor any of their contractors, subcontractors, or their employees, makes any warranty, express or implied, or assumes any legal liability or responsibility for the accuracy, completeness, or usefulness of any information, apparatus, product, or process disclosed, or represents that its use would not infringe privately owned rights. Reference herein to any specific commercial product, process, or service by trade name, trademark, manufacturer, or otherwise, does not necessarily constitute or imply its endorsement, recommendation, or favoring by the United States Government, any agency thereof or any of their contractors or subcontractors. The views and opinions expressed herein do not necessarily state or reflect those of the United States Government, any agency thereof or any of their contractors.

Printed in the United States of America. This report has been reproduced directly from the best available copy.

Available to DOE and DOE contractors from Office of Scientific and Technical Information

PO Box 62

Oak Ridge, TN 37831

Prices available from (615) 576-8401, FTS 626-8401

Available to the public from

National Technical Information Service

US Department of Commerce

5285 Port Royal Rd

Springifeld, VA 22161

NTIS price codes

Printed copy: A08

Microfiche copy: A01 


\title{
Technology Integration Project: Environmental Restoration Technologies Department Sandia National Laboratories
}

\author{
Cecelia V. Williams \\ Environmental Restoration Technologies \\ Sandia National Laboratories \\ Albuquerque, NM 87185-5800 \\ Thomas D. Burford \\ Environmental Restoration Technologies \\ Sandia National Laboratories \\ Albuquerque, NM 87185-5800 \\ Cheryl Ann Allen \\ Tech Reps, Inc. \\ Albuquerque, NM 87110
}

\begin{abstract}
Sandia National Laboratories Environmental Restoration Technologies Department is developing environmental restoration technologies through funding from the U.S. Department of Energy's (DOE's) Office of Science and Technology*. Initially, this technology development has been through the Mixed Waste Landfill Integrated Demonstration (MWLID). It is currently being developed through the Contaminant Plume Containment and Remediation Focus Area, the Landfill Stabilization Focus Area, and the Characterization, Monitoring, and Sensor CrossCutting Program. This Technology Integration Project (TIP) was responsible for transferring MWLID-developed technologies for routine use by environmental restoration groups throughout the DOE complex and commercializing these technologies to the private sector. The MWLID's technology transfer/commercialization successes were achieved by involving private industry in development, demonstration, and technology transfer/commercialization activities; gathering and disseminating information about MWLID activities and technologies; and promoting stakeholder and regulatory involvement. From FY91 through FY95, 30 Technical Task Plans (TTPs) were funded. From these TTPs, the MWLID can claim 15 technology transfer/commercialization successes. Another seven technology transfer/ commercialization successes are expected. With the changeover to the focus areas, the TIP continued the technology transfer/commercialization efforts begun under the MWLID.
\end{abstract}

\footnotetext{
"The work described in this report was performed for Sandia National Laboratories under Technical Task Plan \#AL-2341-05.
} 


\section{DISCLAIMER}

Portions of this document may be illegible in electronic image products. Images are produced from the best available original document. 


\section{Acknowledgements}

The Technology Integration Program efforts are funded by the Office of Science and Technology (OST) under the Department of Energy (DOE) contract number DE-AC0494AL85000.

The authors thank John "Mac" Lankford, Claire Sink, Jeff Lenhart, and Joe Paladino of the Office of Program Integration and Technology Transfer (EM-52) for their funding support and commitment to the technology transfer/commercialization efforts of the MWLID. The material development efforts are part of the Technology Transfer/Commercialization Program instituted by Joe Paladino, and the MWLID's successes were realized because of Joe's guidance. Skip Chamberlain of EM-541 deserves recognition for program direction, support, and funding.

The authors also thank the staff members of the Sandia National Labortories (SNL) Environmental Restoration Technologies (ERT) Department. Jennifer Nelson, the SNL-ERT manager, provided unflagging moral support and labored to supply funding and resources. Sandra Wagner provided logistics support for poster presentations and served as an information resource. Patty Comiskey was instumental in facilitating numerous meetings. Dianne Padilla and Merlyn Liberty of Tech Reps, Inc., representatives who work in the SNLERT office, provided continued support for day-to-day tasks. 
This Page Intentionally Left Blank 


\section{Table of Contents}

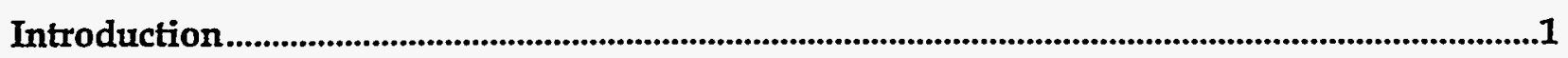

Materials Development.................................................................................................................................

Data Collection ...............................................................................................................................................

Environmental Management Licensing Survey ............................................................................

Market Analysis.............................................................................................................................................4

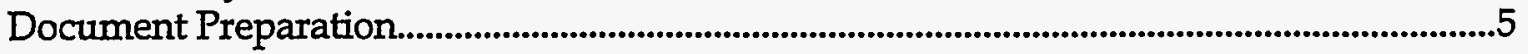

ProTech...................................................................................................................................................

Environmental Restoration Technologies Department Poster........................................................6

Environmental Communications Database ...............................................................................................

Involvement with Industry .....................................................................................................................9

Environmental Bottom Line ..................................................................................................................

Other Small Business Workshops.........................................................................................................10

Technology Transfer/Commercialization Efforts and Successes.....................................................13

Technology Transfer..................................................................................................................................13

Commercialization Planning Workshops ...........................................................................................15

Technology Transfer/Commercialization Successes......................................................................16

Completed Technology Transfer/Commercialization ................................................................22

Pending Technology Transfer/Commercialization ..................................................................27

International Technology Transfer/Commercialization Successes................................................29

Regulatory Involvement ............................................................................................................................31

Research, Development, and Demonstration Permits.........................................................................31

Thermal Enhanced Vapor Extraction System ..............................................................................31

Electrokinetic Remediation of Chromium from Unsaturated Soil..........................................31

In-Situ Gaseous Reduction System .................................................................................................32

Western Governors' Association ................................................................................................................32

Public Relations ..................................................................................................................................33

Media Coverage .....................................................................................................................................3

Awards ..........................................................................................................................................................3

Public Participation...............................................................................................................................35

Public Participation Plan ..........................................................................................................................35

Western Governors' Association - DOIT Activities .......................................................................36

Sandia Site Implementation Team ........................................................................................................37

Community Leaders Workshop .............................................................................................................40

Public Participation Planning and Training Workshops ..................................................................40

Information Exchange ....................................................................................................................................4

Evaluation of Technology Transfer/Commercialization Activities...................................................43 


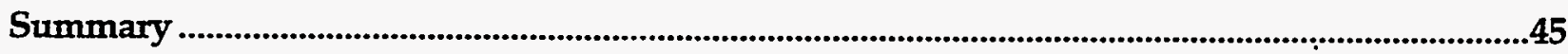

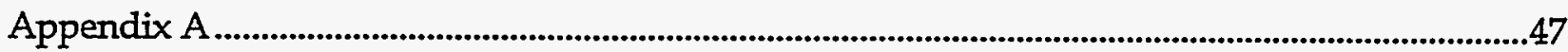

Appendix B

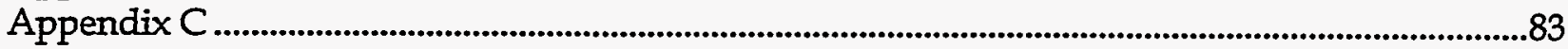

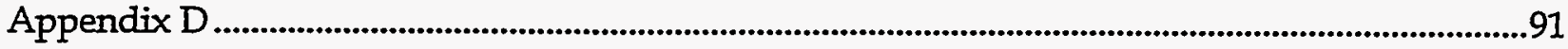

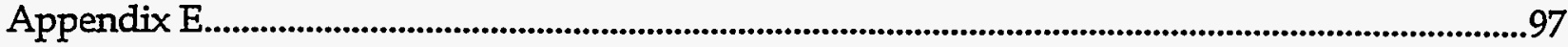

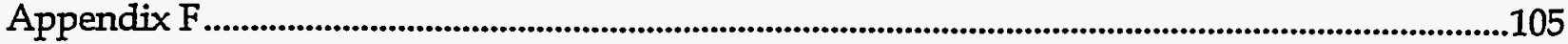

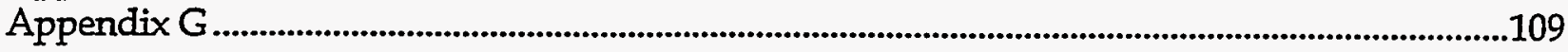

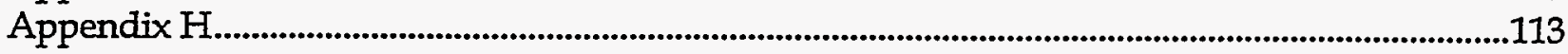

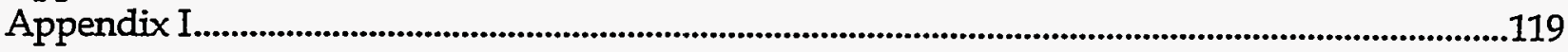

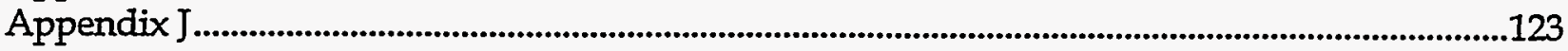

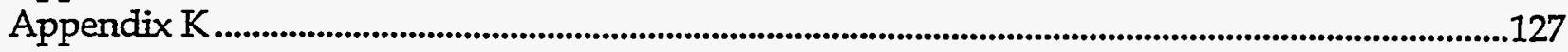

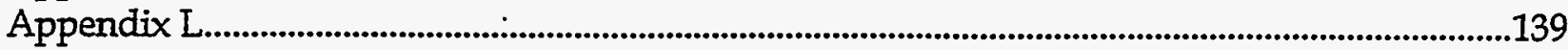

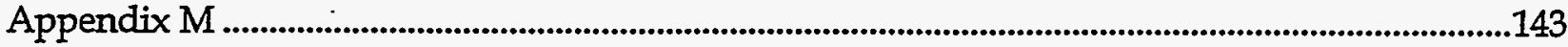

\section{List of Tables}

Table 1. Transferred (noncommercial use) MWLID technologies................................................17

Table 2. Commercialized MWLID technologies...............................................................................20

Table 3. OST metrics and associated MWLID/SNL-ERT achievements ..........................................44 


\section{Nomenclature}

\begin{tabular}{|c|c|}
\hline AIPC & All Indian Pueblo Council \\
\hline ALCD & Alternative Landfill Cover Demonstration \\
\hline ANL & Argonne National Laboratory \\
\hline CEDRA & Center for Economic Development, Research and Assistance \\
\hline CMSTIP & Characterization, Monitoring and Sensors Technology Integrated Program \\
\hline CMW & Charles Machine Works, Inc. \\
\hline CoRe & Community Relations Team \\
\hline CPWTM & Commercialization Planning Workshops \\
\hline CRADA & Cooperative Research and Development Agreement \\
\hline CWL & Chemical Waste Landfill \\
\hline DCCS & Drill Cuttings Containment System \\
\hline DOE & Department of Energy \\
\hline DOI & Department of the Interior \\
\hline DOIT & Committee to Develop On-site Innovative Technologies \\
\hline EDA & Electrochemical Design Associates \\
\hline EM & Environmental Management \\
\hline EM Imaging & Electromagnetic Imaging \\
\hline EPA & Environmental Protection Agency \\
\hline ER & Environmental Restoration \\
\hline ERT & Environmental Restoration Technologies \\
\hline ERTD & Environmental Restoration Technologies Department \\
\hline ESTC & Engineering Software Transfer Center \\
\hline IGRS & In Situ Gaseous Reduction System \\
\hline IITRI & Illinois Institute of Technology Research Institute \\
\hline INEL & Idaho National Engineering Laboratory \\
\hline KAFB & Kirtland Air Force Base \\
\hline LANL & Los Alamos National Laboratory \\
\hline LAMS & Landfill Assessment and Monitoring System \\
\hline LLNL & Lawrence Livermore National Laboratory \\
\hline MTA & Magnetometer Towed Array \\
\hline MWL & Mixed Waste Landfill \\
\hline MWLID & Mixed Waste Landfill Integrated Demonstration \\
\hline NMED & New Mexico Environment Department \\
\hline NMSU & New Mexico State University \\
\hline ORNL & Oak Ridge National Laboratory \\
\hline ORTA & Office of Research Technology Application \\
\hline OST & Office of Science and Technology \\
\hline PI & principal investigator \\
\hline PNL & Pacific Northwest Laboratory \\
\hline ProTech & Prospective Technology Communications System \\
\hline PSL & Physical Science Laboratory \\
\hline RCRA & Resource Conservation Recovery Act \\
\hline $\mathrm{RB}$ & Radioactive Burial \\
\hline RD\&D & Research, Development and Demonstration \\
\hline $\mathrm{RIM}$ & Method \\
\hline
\end{tabular}


SBA

SEDSS

SERDP

SNL

SPIWG

SSIP

SSTT

STOLS

TA

TEVES

TIP

TTP

UCAP

VOC

WERC

WIPP

WGA

WHO

WSRS

XRF
Small Business Association

Sandia Environmental Decision Support System

Strategic Environmental Research and Development Project

Sandia National Laboratories

Sandia Public Involvment Working Group

Sandia Site Implementation Plan

Sandia Site Implementation Team

Surface Towed Ordnance Locator System

Technical Area

Thermal Enhanced Vapor Extraction System

Technology Integration Project

Technical Task Plan

unlined chromic acid pit

volatile organic compound

Waste-management Education and Research Consortium

Waste Isolation Pilot Plant

Western Governors' Association

Westinghouse Hanford Operations

Westinghouse Savannah River Site

$X$-ray Flourescence Spectroscopy 


\section{INTRODUCTION}

The Environmental Restoration Technologies (ERT) Department at Sandia National Laboratories (SNL) is developing environmental restoration technologies through funding from the U.S. Department of Energy's (DOE's) Office of Science and Technology (OST). This technology development in the past was administered through the Mixed Waste Landfill Integrated Demonstration (MWLID). It is currently directed through the Contaminant Plume Containment and Remediation (Plume) Focus Area, Landfill Stabilization Focus Area, and the Characterization, Monitoring Sensor Cross-Cutting Program. The MWLID was hosted by the SNL Environmental Restoration Technologies Department (ERT) from October 1991 to May 1995. It has demonstrated, assessed, and transferred technologies and systems that lead to faster, better, cheaper, and safer in situ characterization and monitoring of landfills in arid environments that contain hazardous and mixed waste. Key goals of the MWLID Technology Integration Plan (TIP) are routine use of these technologies by environmental restoration groups throughout the DOE complex and commercialization of these technologies to the private sector. Specifically, the MWLID worked to facilitate the involvement of outside participants in its activities, to hasten the adoption of successfully demonstrated technologies by the DOE and other federal agencies, and to expedite the transfer of technologies to the private sector for commercialization.

The efforts of the MWLID have been reassigned to the Landfill Stabilization and Plume Focus Areas. The SNL-ERT now serves as the lead for the Landfill Stabilization Focus Area's Low Level and Other Contaminants in Arid Environments product line and the Plume Focus Area's Heavy Metals and Radionuclides product line. The Office of Environmental Restoration and Waste Management is charged with bringing all DOE waste sites into compliance with federal, state, and local regulations. The TIP continues to facilitate the commercialization and transfer of innovative environmental technologies to private industry to help meet this requirement. 
This Page Intentionally Left Blank 


\section{MATERIALS DEVELOPMENT}

The Technology Integration Project (TIP), for the MWLID, developed and distributed information to the DOE's Office of Environmental Restoration (EM-40), industry, regulators, and the general public to facilitate their efforts with technology transfer and commercialization. Information is essential to allay stakeholder apprehensions and hasten regulatory acceptance of innovative technologies. The materials development plan of the MWLID required that the MWLID provide activities information to members of the Technology Integration Network, technology summaries to the Environmental Management (EM) 30/40 field program, and technology needs to DOE headquarters and/or field procurement, industry, academia, and the public. The SNL-ERT continues these efforts. It has reached these varied audiences by gathering data about SNL-ERT technologies for technology summaries, articles, brochures, and fact sheets; collecting, reviewing, and editing the SNL input into the Prospective Technology (ProTech) Communications System; developing and displaying the MWLID/SNL-ERT poster; and assisting with the development and administration of the Environmental Communications Database. The TIP is continuing these processes under the new OST Focus Area structure. The processes and systems are described below.

\section{Data Collection}

The TIP directed the collection of information neccesary to guide technology transfer/commercialization efforts and to promote MWLID activities and technologies. Data collection activities included surveying principal investigators (PIs) to determine licensing opportunities, performing a market analysis of SNL technologies included in the Landfill Stabilization and Plume Focus areas, gathering information for OST and MWLID documents, and suppling information for numerous articles.

\section{Environmental Management Licensing Survey}

The EM Licensing Survey was developed to identify possible EM licensing opportunities at SNL. More than 100 EM-50-developed technologies have been identified at SNL; they represent the pool of possible licensing opportunities. The TIP worked with the SNL Technology Transfer and Commercialization Center to query the PIs on the status of their Technical Task Plans (TTPs) from FY90-94. The purpose of the survey was to facilitate commercialization of SNL-developed technologies by identifying promising technologies and furthering development and commercialization with industry partners. The steps followed to meet the survey's objective were:

1. Filter, separate, and classify TTPs according to technologies.

2. Log TTPs in spreadsheet.

3. Read descriptions in depth to determine technologies that may result from the project. 
4. Scan available and relevent databases to determine whether a technical advance form was previously filed for any of these technologies.

5. Phone/meet with individual inventors to learn more about the project, confirm information already collected in the spreadsheet, and ask additional questions regarding project status and history.

6. Prioritize technologies based on data collected.

7. Develop commercialization strategies for priority technologies.

After completing Steps 1-6, the SNL TIP reported its findings in the EM-50-funded TTPs Matrix (see Appendix B). The survey results are summarized as follows:

Projects initially identified as having the potential for developing technology:

- TTP projects omitted prior to survey mailing:*

- TTP projects for which surveys were mailed:

- Surveys that were not returned: 20

- Survey responses indicating that no technology was/will be developed: 24

- Survey responses indicating that the TTP was never funded or was combined with another TTP:

- Projects for which the responsible PI could not be located: 3

- Survey responses indicating that a technology was/will be developed:

The results were provided to the SNL Technology Transfer and Commercialization Center for development of commercialization strategies for priority technologies. This should result in the advancement of appropriate technology transfer strategies for those technologies with the greatest commercialization potential.

\section{Market Analysis}

The Landfill Market Analysis and technology-specific market analyses were initiated by the TIP and continue under the new Focus Area structure. The SNL-ERT contracted with the Center for Economic Development and Reserach Assistance (CEDRA) at New Mexico State University (NMSU) to perform a market assessment and analysis. The purpose of the analysis is to facilitate the technology transfer and commercialization of SNL-ERT-developed technologies for arid and semi-arid landfill and remediation sites. This work is focusing on those SNL technologies funded by the Landfill Stabilization Containment Focus Area, the Contaminant Plume Focus Area, and the Characterization, Monitoring and Sensor Technology Cross-Cutting Program.

\footnotetext{
* These technologies were omitted due to lack of project funding.
} 
The project consists of two phases: Phase I - Arid and Semi-Arid Landfill Market Assessment and Analysis, and Phase II - Individual Technology Market Assessment and Analysis. Phase I consisted of a study to identify DOE needs and market size followed by an analysis of the private-sector needs and market size in 17 arid and semi-arid states. Phase I was compiled from a secondary literature search consisting of CERCLIS, EPA Record of Decisions, Department of Energy Installations and Sites, Department of Defense Landfill and Radioactive Sites, No Further Remedial Action Planned (NFRAP), RCRA Subtitle D Solid Waste Disposal Facilities, RCRA Subtitle S Hazardous Waste Disposal Facilities, and state environment departments. Phase II consisted of a series of technology-specific market analyses to research specific environmental, mixed-waste landfill remediation technologies in relation to market factors. The complete Statement of Work directing these market analyses is included as Appendix C. Both phases of the market analysis were completed in January 1995.

\section{Document Preparation}

The TIP has collected data on OST Environmental Restoration technologies for the following documents (Complete listing of news releases, publications, and electronic media coverage are given in Appendix D):

- OST Success Document: MWLID Input

- MWLID Brochure

- Directional Drilling Brochure

- Technology Fact Sheets for MWLID Technologies

- Technology Catalog Input

- Base Line Technology Profiles .

- Articles on Magnetometer Towed Array and SEAMISTTM in conjunction with Technology Transfer Office for presentation by former SNL president A. Narath to DOE Secretary O'Leary.

- Articles on Directional Drilling, Dry Barriers, Subsurface Barriers, SitePlanner ${ }^{\mathrm{TM}} /$ PLUME, Sonic Drilling, Drill Cuttings Containment System (DCCS), Thermal Enhanced Vapor Extraction System (TEVES), Alternative Landfill Cover Demonstration (ALCD), Landfill Assessment and Monitoring System (LAMS), and Cross Borehole Electromagnetic Imaging (EM Imaging).

\section{ProTech}

The Prospective Technology (ProTech) Communications System is a computer-based communication tool for describing environmental technologies. It was developed by Battelle Seattle Research Center in support of DOE's OST. The TIP beta tested ProTech for the MWLID. It was designed to reach an audience who has a stake in a technology's development and deployment (i.e., regulators, special interest groups, citizens in communities where the technology may be used, potential industrial partners, and users of the technology). 
The purpose of ProTech is to facilitate public understanding of innovative technologies and involve stakeholders in the development process so that their interests and concerns can be identified and addressed by the technology developers before a technology has been demonstrated. Stakeholder (public, industry, and regulatory) acceptance of innovative technologies is crucial for hastening technology deployment.

ProTech is a Macintosh HyperCard-based application. The technical input was written by the principal investigators (PIs) of the technologies, and peer reviewed by scientists and engineers from a variety of organizations to ensure quality. It provides a technology description and information on the site where each technology is being demonstrated, and it defines the associated site problems and innovative technology using maps, text, and diagrams. The system allows users to compare innovative technologies to currently used (baseline) technologies. Some areas of comparison include technical performance, cost, ease of use, and regulatory acceptability. ProTech version 3.1 categorizes MWLID technologies under the following four areas:

- Drilling,

- Characterization and Monitoring,

- Treatment, and

- Containment/Disposal.

The utility of the ProTech technology profiles is invaluable. These profiles were the basis for the MWLID input into EnviroTrade and the OST's Technology Catalogue. Additionally, these profiles were used to educate the Commercialization Planning Workshop $\left(C P W s^{T M}\right)$ faculty on MWLID technologies. The TIP also used the profiles to prepare a fact sheet on each of the technologies.

The prototype version of ProTech was accepted by the DOE for a national system. The most recent version of ProTech is available on the World-Wide Web as ProTech Online. Its address is:

$$
\begin{gathered}
\text { http://texas.pnl.gov:2080/WEBTECH/menu.html } \\
\text { or } \\
\text { http://www.ern.doe.gov }
\end{gathered}
$$

\section{Environmental Restoration Technologies Department (ERTD) Poster}

The TIP directed the design and fabrication of a modular poster featuring its efforts in characterization, remediation, containment, and technology transfer/commercialization. The poster consists of interchangeable panels featuring $15 \mathrm{MWLID}$ technologies and the technology transfer/commercialization successes of six MWLID technologies. It is designed to give a brief description and pictorial view of technologies under development and technologies that have been transferred and/or commercialized. The ERTD Poster has been displayed at numerous locations including technical exhange meetings, environmental conferences, SNL special 
events, ERTD tours, an OST midyear review, and several public facilities in Albuquerque, NM (see Appendix E).

The TIP also directed the design of the brochures for the MWLID and Hybrid Directional Drilling as well as fact sheets that provide text and color graphics featuring 17 characterization, remediation, and containment technologies developed under the MWLID. These include:

- Cross Borehole Electromagnetic Imaging

- Dry Barrier Applications

- Magenetometer Towed Array

- Subsurface Barrier Emplacement

- Design of Capillary Barriers

- Magnetometer Towed Array

- Moisture Logging

- Landfill Assessment and Monitoring System (LAMS)

- Alternative Landfill Cover Design

- Environmental Measurement-While-Drilling (EMWD)

- Electrokinetic Remediation of Chromium

- In-Situ Gaseous Reduction System

- Stripping Analysis

- Vadose Zone Monitoring System

- Thermal Enhanced Vapor Extraction System (TEVES)

- Flow Probe Chemical Analyzer

- Fiber Optic and TDR Sensors for the Cone Penetrometer

\section{Environmental Communications Database}

Participants of the Environmental Bottom Line (see the Environmental Bottom Line section, page 9) identified the need for a database of businesses interested in receiving. information from DOE, SNL, and Los Alamos National Laboratory (LANL) regarding business opportunities in environmental restoration and waste management. The Environmental Communications Database meets this need.

The Environmental Management Program at LANL and the MWLID Technology Integration Program at SNL have jointly developed the database designed to provide environmental businesses with information on upcoming environmental procurements at each of the laboratories and to develop a system within each laboratory for tracking these procurements. The database consists of two sections:

- Part A: An Environmental Business Profile that provides input for the master "mailing list." Initial input consists of approximately 280 businesses identified from contacts made at the Environmental Bottom Line, the joint LANL-SNL Small Business Workshop.

- Part B: A Business Tracking System that provides a mechanism for tracking all - environmental procurements, contracts, Cooperative Research and Development Agreements (CRADAs), Work for Others, etc. 
The prototype was completed and tested at the New Mexico Conference on the Environment held April 27-29, 1994. The response by the environmental business community was overwhelming: 60 additional requests were made by companies requesting to be added to the database. The SNL-ERT and LANL continue to receive requests. By May 1995, the database had listed 374 privately owned companies and 72 government agencies, for a total of 446 entries. The database identifies 237 businesses that have characterization, remediation, and/or treatment expertise. Listings of New Mexico businesses total 295, of which 231 have expertise in characterization, remediation, and/or treatment. Of these, 73 are classified as small businesses.

The database can be used for a variety of services including:

- serving as a locator for small businesses to find other environmental businesses and establish partnerships where together they can provide a full complement of environmental assessment and remediation skills,

- hastening information dissemination about opportunities at the laboratories available to environmental businesses, and

- allowing federal procurement officials and environmental restoration personnel to readily locate companies capable of completing desired work.

Database-specific funding is no longer available; thus input of new businesses into the database has slowed. Use of the database by the procurement office and the Office of Research Technology Application (ORTA) has not yet begun. The database is a completely new method for them and needs to be presented to procurement management and ORTA as a time-saving tool.

The database is accessible through Internet with an IP address (128.165.42.26). The software needed to access the database (" $4 \mathrm{D}$ Client" and "Glided Tour") are available from Sarah Hayes at LANL and Cecelia V. Williams at SNL. The SNL Supplier Relations and Environmental Restoration departments have been provided access to the database. 


\section{INVOLVEMENT WITH INDUSTRY}

The Technology Integration Project (TIP) for the MWLID developed a relationship with industry to hasten technology transfer and commercialization. The TIP will continue these efforts under the new OST Focus Area structure. To develop a successful relationship with industry, the TIP seeks to establish a link between industry and the national laboratories that allows exchange of information, ideas, resources, and experience. Efforts to build an industry/laboratory relationship include participation in the Environmental Bottom Line and other small business workshops. These two activities are described below.

\section{Environmental Bottom Line}

The Environmental Bottom Line (August 1993), a workshop sponsored by DOE, SNL, LANL, and the TIP-MWLID, was a briefing for industry and small business. The goal of the workshop was to inform participants of the business opportunities in the DOE Environmental Restoration and Waste Management Programs at SNL and LANL. These opportunities include environmental research, cleanup, and technology commercialization. The state of $\mathrm{New}$ Mexico small business assistance programs, Small Business Association (SBA) small business programs, and the international marketplace were also discussed. Claire Sink, director of the Technology Integration Program, provided information on the DOE-EM mission. Joseph Paladino, manager of the Small Business Technology Integration Program, discussed EM business programs. Ron Curry, deputy director of the New Mexico Environment Department (NMED), addressed the regulatory issues of conducting environmental business in the state.

The workshop participants numbered 250, including speakers, booth presenters, hosts, and observers. Demographics identified the attendees as 72 percent industry and 28 percent government and/or government contractors. Business attendees were classified as follows:

According to size:

$44 \%$ Large business

$56 \%$ Small business, of which

95\% New Mexico

5\% Other (Arizona, Colorado, Florida, Illinois, and Washington, D.C.)

According to general business type:

68\% Environmental firms

$32 \%$ Nonenvironmental firms 
According to specific business type (Many businesses were listed in multiple categories.):

$67 \%$ Consultants

$37 \%$ Remediation

$30 \%$ Characterization/monitoring

19\% Treatment

13\% Transportation/storage

$43 \%$ Other (includes construction, engineering, testing, computer or public services, design, equipment, etc.)

The New Mexico contingent represented $91 \%$ of the government and/or goverm:ent contractor participants. They were classified as:

$71 \%$ DOE, LANL, SNL, and other federal laboratories

$25 \%$ New Mexico state, county, or city governments

$4 \%$ Universities

The response to the briefing was very positive. Many participants felt that the workshop was an ideal forum for networking with the laboratories, the state, DOE, and other small businesses. Participants said they would attend future workshops and hoped this new openness would continue. The key concern of industry was the potential for working with the laboratories and the opportunities for commercialization. Specific comments expressed by the participants include the following:

- Specify information regarding DOE-wide and local procurement and subcontracting opportunities.

- Develop a database of businesses interested in receiving information from DOE and the laboratories.

- Create a more responsive, pra::_cal, and economical procurement process for small businesses or they will not be able to compete.

- Provide more marketing professionals to work with the technical people to help with the technology transfer process.

- Standardize rules at the laboratories.

- Create an exchange program between the DOE laboratories and small businesses to allow for a better understanding of how each organization works.

- Establish better channels of communication between technical personnel and procurement personnel.

\section{Other Small Business Workshops}

In November 1993, a representative of the TIP-MWLID presented and participated in (1) the Hazardous and Mixed Waste Opportunities training session of the Environmental Small Business Workshop: Bridges to Environmental Opportunities, held at Lawrence Livermore National Laboratory (LLNL) in California and (2) the Regional Environmental Business Interchange held at Westinghouse Hanford Operations (WHO) in Oregon. 
The LINL workshop informed small businesses of procurement, technology development, and technology transfer opportunities for environmental management services and materials at the DOE's laboratories. The Hazardous and Mixed Waste Opportunities training session provided information on sites, current contracts at the laboratories, identification of commodity items repeatedly purchased, forecasts of future business opportunities, and the laboratory contracts award process.

The WHO workshop shared with businesses the problems and opportunities available in Hanford's environmental cleanup. The mechanisms for taking advantage of these opportunities were discussed. Informal opportunities to discuss the MWLID and its mission were provided at networking functions, informational booths, and at site tours. 
This Page Intentionally Left Blank 


\section{TECHNOLOGY TRANSFER/COMMERCIALIZATION EFFORTS AND SUCCESSES}

Key goals of the SNL-ERT are to demonstrate innovative environmental technologies, to transfer these technologies to environmental restoration groups throughout the DOE complex by routine use, and to commercialize these technologies to the private sector. These goals had been met through the TIP-MWLID and continue under the new DOE Focus Area structure. The SNL-ERT is continuing these efforts by working to facilitate the involvement of outside participants in its activities, to hasten the adoption of successfully demonstrated technologies by the DOE complex and other federal agencies, and to expedite the transfer of technologies to the private sector for commercialization.

\section{Technology Transfer}

Technology transfer is recognized as a two-way effort; that is, technology is transferred both in and out of SNL. Developing and innovative technologies come to the SNL-ERT from industry, universities, government agencies, other national laboratories, and within SNL. In addition, technologies must leave the SNL-ERT for use at DOE environmental restoration sites or other sites. They may be commercialized. Because this two-way effort exists, the TIP recognizes two goals of its technology transfer efforts: (1) provide mechanisms for the "private sector," other government agencies, and other national laboratories to use their creativity and entrepreneurial spirit in concert with SNL to demonstrate innovative environmental technologies (technology transfer in), and (2) facilitate the use and possible commercialization of the successfully demonstrated technologies (technology transfer out).

Formerly the MWLID, and presently the SNL-ERT, brings together the best talent and innovation available, leverages DOE dollars with private investment, improves technology, and encourages technology transfer. The SNL-ERT (as the MWLID) has leveraged over \$1.2 million of OST funding with services and funding from industrial partners since FY91, when the MWLID was organized. This leveraged funding has reinforced both DOE's and SNL-ERT's commitment to develop technologies with committed partnerships to fulfill the OST mission.

Technology transfer into SNL for further development with outside partners has been accomplished by:

- establishing partnerships between industry and the national laboratories,

- utilizing CRADAs,

- obtaining support from other national laboratories and various research laboratories, and

- collaborating with universities.

One of the SNL-ERT's primary goals is to develop research alliances with private industry, universities, other laboratories, and federal agencies to demonstrate innovative technologies. Alliances have been developed to employ innovative drilling, sensing, sampling, 
remediation, and containment technologies. Private industry alliances have been formed with Charles Machine Works, Inc. (CMW) and the Water Development Corporation to develop directional/horizontal boring and sonic drilling. Sensing and sampling capabilities are being developed through alliances with ConSolve, Inc., Rust Geotech, GEO-CENTERS, Inc., Science \& Engineering Associates (SEA), Scitek, Stolar, Inc., and Troxler Corporation. Remediation and containment alliances include the Illinois Institute of Technology Research Institute (IITRI), DuPont, Daniel B. Stephens and Associates, as well as university and national laboratory involvement. Partners from other national laboratories, various research laboratories, universities, industry, and government also contribute to the development of new technologies. (The development partners for FY94 and FY95 are listed in Appendix F.)

Like the MWLID, the SNL-ERT integrates mature technologies from these sources for demonstration. For example, an SNL-ERT-funded migration barrier cover is being jointly developed by Colorado State University (CSU) and LANL. In another demonstration, IITRI is the research partner on the TEVES project, which combines the use of soil heating methods developed by IITRI with vacuum extraction methods developed by industry and an off-gas treatment system engineered by SNL.

The MWLID/SNL-ERT current technology development with industry included the following projects listed by fiscal year:

FY94 Projects: 25 Technical TTPs

- Seven national laboratories (excluding SNL), six research laboratories, 16 industry partners, seven universities, and four government agencies participated on technical projects.

- Two CRADAs were in place:

1. ConSolve and ANL for the development of SitePlanner and PLUME.

2. Scitek and PNL for the development of $X$-Ray Fluorescence Spectroscopy (XRF).

- A No-Cost Agreement continued between CMW and SNL for developing equipment for Hybrid Directional Boring. A second similar agreement is being developed for the Environmental Measurement-While-Drilling Project.

- The Waste-management Education and Research Consortium (WERC) participated in several different technology demonstrations.

\section{FY95 Projects: 16 Technical TTPs}

- Two national laboratories (excluding SNL), four research laboratories, eight industry partners, four universities, and five government agencies participated on technical projects.

- Groundwork was laid for interstate cooperation between environmental regulators through the efforts of the Sandia Site Implementation Team (SSIT) of the ALCD and the Western Governors' Association (WGA).

- Leedshill-Herkenhoff, an Albuquerque engineering firm, contracted with the dry barriers industry partner Daniel B. Stephens \& Associates to design a dry barrier for a LANL project.

- GEO-CENTERS signed two international agreements for further development and use of the Magnetometer Towed Array (MTA).

- As a result of successful demonstration and commercialization of Stripping Analysis, Environmental Technologies Group, Inc. is marketing a handheld Stripping Analysis device, which became commercially available in June 1995. 
- Two departments at SNL worked with the SNL Technology Transfer Office, the All Indian Pueblo Council (AIPC), the State of New Mexico, CMW, and CERL, Inc. to identify a school suitable for demonstrating a radon remediation technique using directional drilling.

The SNL-ERT is also aggressively developing partnerships with state, municipal, and tribal groups to broaden the knowledge and use of its achievements. As the TIP-MWLID, staff members worked with the New Mexico Environmental Alliance to apply innovative technical solutions to industrial environmental problems. The TIP staff also worked with the New Mexico Association of Counties, the New Mexico Municipal League, New Mexico Hazardous Waste Management Society, the AIPC, and citizens groups.

SNL and the SNL-ERT are active participants in the DOE-sponsored WERC, a research partnership including the New Mexico universities, national laboratories, and the Navajo Community College. The SNL-ERT also actively supports the Partnership for Environmental Technology Education, Youth Opportunity Training, Work-Study Training, and Summer Employment for Minority Youth. The SNL-ERT provides internships and graduate research opportunities for students and educators to challenge them to become involved with innovative solutions to environmental problems.

\section{Commercialization Planning Workshops}

Through the MWLID TIP, commercialization planning workshops (CPWs $\left.{ }^{\mathrm{TM}}\right)$ were offered to aid the principal investigators (PIs) and their private sector partners in marketing their technologies to assist in the transfer of these technologies. Two CPWs ${ }^{\mathrm{TM}}$ were held for the MWLID and the Characterization, Monitoring and Sensors Technology Integrated Program (CMSTIP) PIs. The CPWs were sponsored by the OST's EM-52 Technology Integration Program, the TIP-MWLID, and SNL-ERT. They were funded by OST EM-52 (through HAZWRAP) and by the TIP-MWLID. The workshops were conducted by Mohawk Research Corporation with a faculty of nine industry and commercialization experts.

The purpose of the CPWs was to provide business assessments of selected MWLID and CMSTIP technologies and commercialization planning assistance to the PIs. The aim of the assistance was to accelerate technology commercialization and enhance the return on federal investment in technology development in the federal laboratories. The workshops were designed to (1) help the PIs develop a focused, pragmatic commercialization plan for each of the technologies presented; (2) increase their awareness of private sector methods, techniques, and resources for moving new technologies into the marketplace; (3) encourage the PIs and their industrial partners to explore alternate applications of the technology in both the DOE complex and the private sector; (4) stimulate post-workshop participation and implementation of the commercialization action plans; and (5) track accomplishments of PIs. The commercialization plans developed by the principal investigators covered such topics as technical development, market analysis, business development, and licensing potential.

The CPWs were conducted in a seminar format with the PIs concurrently working on technology development and commercialization plans. The faculty worked as a team to provide individual, project-specific consultation. As practitioners they provided practical 
advise and referrals. Seminar topics included Strategies for Commercialization, Engineering and Prototype Development, Market Analysis, Patents Licensing, Sources of Capital, and Developing a Commercialization Plan. The commercialization experts also performed a business assessment and analysis of the commercialization potential of the technologies represented at the workshop.

Although the workshops were specifically dedicated to working with the 21 PIs (18 from the MWLID and 3 from the CMSTIP; See Appendix G), several non-active participants were allowed to observe the process. Observers included representatives from DOE Headquarters, DOE/ALO Energy and Special Programs, HAZWRAP, MWLID, SNL Technology Transfer and Commercialization Center, Oak Ridge National Laboratory (ORNL), LANL, and LLNL.

The CPWs were extremely successful in accomplishing the established goals. Each PI left the workshops with an improved understanding of the technology transfer and commercialization process and with a draft technology transfer/commercialization plan. The faculty assessment indicated that each PI has a process or product that can be successfully transferred. Both the PIs and observers rated the workshops a success (2.5 on a scale of 3 ). Complete evaluation results are included in Appendix $\mathrm{H}$.

Responses indicated a need for market analyses for the MWLID technologies and a need for funding follow-up support to the PI by the CPW-type experts and the SNL Technology Transfer and Commercialization Center.

\section{Technology Transfer/Commercialization Successes}

Significant accomplishments of the TIP-MWLID and SNL-ERT include transfer and commercialization of many technologies. Successful transfer occurs when a government agency accepts or uses the technology at a government site. Successful commercialization occurs when private industry markets the technology. Successfully tranferred and/or commercialized MWLID/SNL-ERT technologies are described in the sections below.

Additionally, the contributions of the MWLID/SNL-ERT have been recognized by government officials. In 1994, the governor of New Mexico, in a letter to Secretary of Energy Hazel O'Leary, commended the significant contributions of the MWLID to the state economy through commercializing environmental technologies, reducing environmental cleanup costs, and advancing technical education through WERC.

Technology transfer and commercialization successes are summarized in the following tables. Table 1 lists the MWLID technologies that have been transferred, the organization that used the technology, the year(s) the transfer was made, and the purpose for the transfer. Table 2 lists each commercialized technology, the company marketing it, its date of commercialization, the initial customer, and the method of commercialization. 
Table 1. Transferred MWLID Technologies

\begin{tabular}{|c|c|c|c|}
\hline Technology & User & Date & Purpose of Transfer \\
\hline $\begin{array}{l}\text { Advanced In Situ } \\
\text { Moisture Logging }\end{array}$ & $\begin{array}{l}\text { Sandia National Laporatories } \\
\text { Environmental Restoration }\end{array}$ & 1994 & Monitor soil moisture/density in deep vadose zone boreholes. \\
\hline \multirow[t]{8}{*}{ SEAMIST TM } & $\begin{array}{l}\text { Lawrence Livermore National } \\
\text { Laboratory }\end{array}$ & 1991 & $\begin{array}{l}\text { Two systems installed to track movement and concentration of both the liquid } \\
\text { and vapor phases of tritated water plume to depth of } 40 \text { feet. }\end{array}$ \\
\hline & Waste Isolation Pilot Plant & 1992 & $\begin{array}{l}\text { Membranes coated with liquid-indicating and wicking layers mapped and } \\
\text { measured underground brine flows. }\end{array}$ \\
\hline & Westinghouse Hanford Operations & 1992 & Two systems emplaced to monitor a carbon tetrachloride plume. \\
\hline & Los Alamos National Laboratory & 1992 & $\begin{array}{l}\text { Transported vapor sampling tubes and absorbent collectors to } 230 \text { feet } \\
\text { horizontally beneath a landfill for tritium and volatile organic compound } \\
\text { sampling. }\end{array}$ \\
\hline & $\begin{array}{l}\text { Sandiá National Laboratories } \\
\text { Environmental Restoration }\end{array}$ & 1992 & $\begin{array}{l}\text { Used in conjunction with Thermal Enhanced Vapor Extraction System for } \\
\text { critical characterization data collection. Also used to deploy borehole sensors } \\
\text { at CWL for MWLID characterization. }\end{array}$ \\
\hline & Westinghouse Savannah River Site & 1992 & $\begin{array}{l}\text { Three multi-point sampling membranes installed for soil vapor, vapor pressure, } \\
\text { and air permeability measurements in a vapor extraction system. }\end{array}$ \\
\hline & $\begin{array}{l}\text { Lawrence Livermore National } \\
\text { Laboratory } \\
\text { and Weiss Associates }\end{array}$ & 1992 & $\begin{array}{l}\text { Two Kevlar reinforced membranes installed inside PVC-cased wells to a depth } \\
\text { of } 155 \text { feet and filled with water to prevent collapse of the PVC casing during } \\
\text { steam injection remediation experiments. Also used for borehole liners. }\end{array}$ \\
\hline & US Department of Agiculture & 1992 & Installed as borehole liners. \\
\hline \begin{tabular}{|l} 
Vadose Zone \\
Monitoring System
\end{tabular} & $\begin{array}{l}\text { Los Alamos National Laboratory } \\
\text { Environmental Restoration }\end{array}$ & 1994 & Modified system used for subsurface assessment and monitoring. \\
\hline
\end{tabular}


Table 1. Transferred MWLID Technologies

\begin{tabular}{|c|c|c|c|}
\hline Technology & User & Date & Purpose of Transfer \\
\hline Hybrid Directional Boring & Kirtland Air Force Base, RB-11 landfill & 1993 & $\begin{array}{l}\text { Drilled horizontal, directional borehole, } 410 \text { feet long, } 40 \text { feet deep, and } 6 \\
\text { inches in diameter. }\end{array}$ \\
\hline \multirow{2}{*}{$\begin{array}{l}\text { Drill Cuttings } \\
\text { Containment System } \\
\text { (DCCS) }\end{array}$} & Westinghouse Hanford Operation & 1994 & $\begin{array}{l}\text { Eliminated contaminated water streams which resulted during site } \\
\text { characterization drilling operations. }\end{array}$ \\
\hline & Westinghouse Hanford Operations & Completed & $\begin{array}{l}\text { Sandia National Laboratories purchased the prototype system and transferred } \\
\text { the unit for use by Hanford. }\end{array}$ \\
\hline $\begin{array}{l}\text { Cross Borehole } \\
\text { Electromagnetic Imaging } \\
\text { (EM Imaging) }\end{array}$ & Kirtland Air Force Base, RB-11 landfill & 1994 & Imaged pits and surrounding soils for plume identification. \\
\hline $\begin{array}{l}\text { Dry Barrier Applications } \\
\text { for Landiflis }\end{array}$ & $\begin{array}{l}\text { Los Alamos National Laboratory } \\
\text { Waste Managment }\end{array}$ & $\begin{array}{c}1996 \\
\text { (planned) }\end{array}$ & $\begin{array}{l}\text { Incorporated into a closure plan for a landfill liner system at the Mixed Waste } \\
\text { Disposal Facility. }\end{array}$ \\
\hline \multirow[t]{2}{*}{$\begin{array}{l}\text { Magnetometer Towed } \\
\text { Array }\end{array}$} & $\begin{array}{l}\text { Sandia National Laboratories } \\
\text { Environmental Restoration }\end{array}$ & 1993 & Classified waste site characterization at Technical Area 2. \\
\hline & Kirtland Air Force Base, RB-11 landfill & 1993 & Non-intrusive site characterization of nine burial pits. \\
\hline \multirow[t]{4}{*}{ ResonantSonic (sm) } & Westinghouse Hanford Operations & 1991-92 & $\begin{array}{l}\text { Bored ground water monitoring wells, a carbon tetrachloride monitoring and } \\
\text { extraction well, and vadose zone characterization boreholes. }\end{array}$ \\
\hline & Sandia National Laboratories & 1993 & $\begin{array}{l}\text { Environmental applications in directional boreholes. Provided characterization } \\
\text { boreholes from outside contaminated zone, the first use of ResonantSonic for } \\
\text { environmental purposes. }\end{array}$ \\
\hline & Westinghouse Hanford Operations & 1993-94 & Bored mutlliple directional boreholes. \\
\hline & Pantex & 1994 & Bored four continuous core boreholes. \\
\hline
\end{tabular}


Table 1. Transferred MWLID Technologies

\begin{tabular}{|c|c|c|c|}
\hline Technology & User & Date & Purpose of Transfer \\
\hline \multirow[t]{5}{*}{ SitePlanner ${ }^{T M}$} & US Department of Agriculture & $1992-94$ & \multirow[t]{5}{*}{$\begin{array}{l}\text { Provide decision makers with a software system for data compilation during } \\
\text { remediation activities (characterization and assessment). }\end{array}$} \\
\hline & Los Alamos National Laboratory & $1992-94$ & \\
\hline & Great Plains Coal Gasification Plant & $1993-94$ & \\
\hline & Idaho National Engineering Laboratory & 1994 & \\
\hline & US Air Combat Command & 1994 & \\
\hline PLUME & Tyndale Air Force Base & 1994 & $\begin{array}{l}\text { Part of an Air Force Civil Engineering Services Agency (ACESA) } \\
\text { project. }\end{array}$ \\
\hline \multirow{5}{*}{$\begin{array}{l}\text { SitePlanner }{ }^{T M} \\
\text { and PLUME }\end{array}$} & Joliet Army Ammunitions Plant & $1992-94$ & Part of an Army Environmental (AEC) project. \\
\hline & Aberdeen Proving Grounds & $1992-94$ & Analyze past sampling program results. \\
\hline & Los Angeles Air Force Base & $1992-94$ & Estimate contamination extent \\
\hline & Weldon Springs & $1993-94$ & Estimate contamination extent. \\
\hline & Kirtland Air Force Base, RB-11 landfill & 1994 & Included in the SERDP. \\
\hline \multirow[t]{2}{*}{ Stripping Analysis } & Westinghouse Hanford Operations & 1994 & Measured uranium in process sewer. \\
\hline & Elison Air Force Base & 1994 & Determined concentrations of lead during field characterization activities at site. \\
\hline $\begin{array}{l}\text { X-ray Fluorescence } \\
\text { Spectroscopy (XRF) }\end{array}$ & Scitek Corporation & 1993 & $\begin{array}{l}\text { Although this technology has not been transferred for use, it is considered } \\
\text { transferred because the development partners signed a CRADA in May } 1993 .\end{array}$ \\
\hline
\end{tabular}


Table 2. Commercialized MWLID Technologies

\begin{tabular}{|c|c|c|c|c|}
\hline \multirow[t]{2}{*}{ Technology } & \multirow[t]{2}{*}{ Company } & \multicolumn{2}{|r|}{ First Commercial Use } & \multirow[t]{2}{*}{ Method of Commercialization } \\
\hline & & Date & Customer & \\
\hline $\begin{array}{l}\text { Advanced In Situ } \\
\text { Moisture Logging }\end{array}$ & Troxler, Inc. & 1994 & $\begin{array}{l}\text { Sandia National Laboratories } \\
\text { Environmental Restoration }\end{array}$ & $\begin{array}{l}\text { Troxler, Inc. retains full rights to the probe. The } \\
\text { company continues to market and improve the probe. }\end{array}$ \\
\hline SEAMIST'M & $\begin{array}{l}\text { Eastman Cherrington } \\
\text { Environmental }\end{array}$ & 1993 & $\begin{array}{l}\text { City of Tucson } \\
\text { Tucson Airport Authority } \\
\text { US Air Force }\end{array}$ & $\begin{array}{l}\text { Science and Engineering Associates, Inc., the } \\
\text { technology developer, sold the patent on SEAMIST to } \\
\text { Eastman Cherrington Environmental in 1993. The } \\
\text { product is being marketed internationally. }\end{array}$ \\
\hline $\begin{array}{l}\text { Vadose Zone } \\
\text { Monitoring System }\end{array}$ & $\begin{array}{l}\text { Science and Engineering } \\
\text { Associates, Inc. }\end{array}$ & 1994 & $\begin{array}{l}\text { Los Alamos National Laboratory } \\
\text { Environmental Restoration }\end{array}$ & $\begin{array}{l}\text { Science and Engineering Associates is marketing the } \\
\text { system as MultiScan }{ }^{T M} \text {. }\end{array}$ \\
\hline Hybrid Directional Boring & $\begin{array}{l}\text { Charles Machine } \\
\text { Works, Inc. }\end{array}$ & 1992 & $\begin{array}{l}\text { Westinghouse Savannah River } \\
\text { Site }\end{array}$ & $\begin{array}{l}\text { Charles Machine Works, Inc., the makers of } \\
\text { DITCHWITCH } \\
\text { In 1992, they introduced a completely separate line of } \\
\text { environmental machinery. The technology is being } \\
\text { marketed internationally. }\end{array}$ \\
\hline $\begin{array}{l}\text { Drill Cuttings } \\
\text { Containment System } \\
\text { (DCCS) }\end{array}$ & Guzzler Manufacturing, Inc. & 1994 & Sandia National Laboratories & $\begin{array}{l}\text { Sandia National Laboratories leased the prototype unit } \\
\text { for testing purposes and is purchasing the unit. } \\
\text { Guzzler does not plan to build additional units, but is } \\
\text { capable of doing so if they receive requests for the } \\
\text { system. }\end{array}$ \\
\hline $\begin{array}{l}\text { Cross Borehole } \\
\text { Electromagnetic Imaging } \\
\text { (EM Imaging) }\end{array}$ & RIMtech, Inc. & 1993 & Rocky Flats & $\begin{array}{l}\text { RIMtech entered the environmental market as a } \\
\text { service company in } 1994 \text {. EM Imaging has been sold } \\
\text { to the Physical Sciences Laboratory at New Mexico } \\
\text { State University. The laboratory is marketing the } \\
\text { technology as Radio Imaging Method (RIM). }\end{array}$ \\
\hline
\end{tabular}


Table 2. Commercialized MWLID Technologies

\begin{tabular}{|c|c|c|c|c|}
\hline \multirow[t]{2}{*}{ Technology } & \multirow[t]{2}{*}{ Company } & \multicolumn{2}{|r|}{ First Commercial Use } & \multirow[t]{2}{*}{ Method of Commerciallzation } \\
\hline & & Date & Customer & \\
\hline $\begin{array}{l}\text { Magnetometer Towed } \\
\text { Array (MTA) }\end{array}$ & GEO-CENTERS, Inc. & 1993 & $\begin{array}{l}\text { Department of Energy } \\
\text { at Sandia National Laboratories } \\
\text { Technical Area II }\end{array}$ & $\begin{array}{l}\text { GEO-CENTERS is commercializing the services of } \\
\text { MTA internationally. Two international agreements } \\
\text { have been signed. }\end{array}$ \\
\hline Directional Sonic Drilling & Water Development, Corp. & 1993 & $\begin{array}{l}\text { Sandia National Laboralories } \\
\text { Chemical Waste Landfill }\end{array}$ & $\begin{array}{l}\text { Water Development is the leading service provider of } \\
\text { sonic directional drilling technology in the Uniled } \\
\text { States. ResonantSonic(sm) technology is being } \\
\text { marketed through a CRADA signed by Water } \\
\text { Development and Pacific Northwest Laboratory in } \\
\text { 1993. }\end{array}$ \\
\hline SitePlanner ${ }^{T M}$ & ConSolve, Inc. & 1992 & $\begin{array}{l}\text { Sandia National Laboratories } \\
\text { Mixed Waste Landfill }\end{array}$ & $\begin{array}{l}\text { Commercialization efforts were conducted through a } \\
\text { CRADA between Argonne National Laboratory and } \\
\text { ConSolve. Consolve is also marketing a less robust } \\
\text { version as SiteView'TM. Both versions are being } \\
\text { marketed internationally. }\end{array}$ \\
\hline PLUME & ConSolve, Inc. & 1994 & $\begin{array}{l}\text { Applied Research Associates } \\
\text { at Tyndale Air Force Base }\end{array}$ & $\begin{array}{l}\text { PLUME was commercialized through a CRADA } \\
\text { between Argonne National Laboratory and ConSolve. }\end{array}$ \\
\hline Stripping Analysis & Radiometer America, Corp. & 1992 & $\begin{array}{l}\text { Sandia National Laboratories } \\
\text { Chemical Waste Landfill }\end{array}$ & $\begin{array}{l}\text { A partnership was established under a no-cost } \\
\text { cooperative agreement. Hardware is available through } \\
\text { Radiometer America. Environmental Technologies } \\
\text { Group, Inc. is marketing a hand-held version. }\end{array}$ \\
\hline $\begin{array}{l}\text { X-ray Fluorescence } \\
\text { Spectroscopy (XRF) }\end{array}$ & Scitek, Corp. & 1996 & Expected commercial application & $\begin{array}{l}\text { A CRADA has been signed for funding } \\
\text { commercialization efforts. }\end{array}$ \\
\hline
\end{tabular}




\section{Completed Technology Transfer/Commercialization (as of FY95)}

Specific technology transfer/commercialization successes of the MWLID/SNL-ERT include the following 15 technologies:

- Advanced In-Situ Moisture Logging System

The Environmental Restoration Project at SNL, through its Site Wide Hydrogeologic Characterization Project, began using the Troxler 4350 probe for soil moisture/density monitoring in deep vadose zone boreholes as part of the Advanced In-Situ Moisture Logging System during the summer of 1994. The probe, which detects leakage during landfill post-closure monitoring, is self-contained; the electronics required to take a reading and to program subsequent readings of moisture content and soil density are contained within the housing of the device. The probe is drawn through an access tube by a computer-monitored winch system and requires no physical electronic connections to the surface. Troxler, the industry partner and patent owner, continues to market and improve the probe.

- SEAMISTTM

The patent for SEAMIST ${ }^{T M}$, an inverting membrane liner used for borehole lining , sample collection, in situ measurements, and transporting sensors downhole without allowing contact between the instruments and the contaminated soils, was sold to Eastman Cherrington Environmental by SEA, the technology developer. Demonstrations were performed at various sites including LLNL, WHO, the Waste Isolation Pilot Plant (WIPP), LANL SNL, WSRS, and Utica, NB, between 1991 and 1995. The first commercial use of the technology was conducted for the City of Tucson, Tucson Airport Authority and the U.S. Air Force in 1993. Eastman Cherrington has several patents pending on the extension of SEAMIST TM for applications both above and below ground. The technology earned a 1994 R\&D 100 Award for Technical Excellence.

The SEAMIST ${ }^{\mathrm{TM}}$ inverting membrane technology has been adapted for use in the Vadose Zone Monitoring System and Pipe Explorer ${ }^{\mathrm{TM}}$. The Vadose Zone Monitoring System incorporates SEAMIST TM, commercially known as Multi Scan ${ }^{\mathrm{TM}}$, for use in the integrated pressure and gas sampling system that has been developed for characterizing and monitoring contaminant transport in soils with deep vadose zones. Pipe Explorer uses the inverting membrane concept to address the problem of detecting/characterizing radioactive contamination inside of pipes and ducts at nuclear process facilities undergoing decontamination and decommisioning activities. This spin-off technology has been successfully developed and demonstrated by SEA under Research Opportunity Announcement (ROA) from DOE Morgantown Energy Technology Center. Funding is provided by the DOE-OST.

- Vadose Zone Monitoring System - Multi Scan ${ }^{\mathrm{TM}}$

The Vadose Monitoring System technology was transferred to the LANL Environmental Restoration (ER) group in August 1994 for subsurface assessment and .monitoring. SNL-ER is using the system in tracer studies at the Chemical Waste Landfill (CWL) SNL and SEA built the integrated pressure and gas sampling system using the SEAMISTTM borehole liner to monitor movement of volatile contaminants in soils with deep 
vadose zones. Demonstrations were conducted at Sandia's CWL in 1994. SEA is marketing the system as MultiScan ${ }^{\mathrm{TM}}$. The commercialized system is a stand-alone field system that performs real-time measurement at up to 64 vapor sampling ports in either single or multiple wells. Applications of the system include monitoring contaminant movement in soils resulting from changes in barometric pressure, verifying the integrity of sub-surface ground barriers using tracer gases, tracking contaminant plume movement on a long-term basis, and monitoring effectiveness of remediation programs.

- Hybrid Directional Boring

CMW, which is best known for its DITCHWITCH ${ }^{\mathrm{TM}}$ product line, is marketing a new class of hybrid directional boring machinery that provides access beneath environmental sites. This system produces a borehole without generating cuttings via a compaction boring technique. Its first commercial use was conducted in 1992 at the WSRS, where CMW drilled a $3^{\prime \prime}$ diameter, 570' horizontal well to a depth from the surface of $40^{\prime}$. The test bed prototype machine is capable of 80,000 pounds of thrust, high torque, and thorough decontamination. The machinery is capable of initiating a borehole at ground level, steering down to a desired depth, continuing along at that depth, then steering back to the surface. The system has potential for use in characterization, monitoring, and remediation of waste sites and ventilation of radon from under buildings. The technology has successfully demonstrated surface-to-surface capability in arid and non-arid climates. In addition to a WSRS application of the technology, a successful demonstration occurred at SNL in 1993. CMW has demonstrated the hybrid directional boring equipment for the international as well as national DITCHWITCH ${ }^{\text {TM }}$ franchises. Additionally, the equipment was demonstrated at an international construction trade show, Bauma '95, in München, Germany during April 1995. Several patent disclosures have been made by SNL and CMW. Hardware in the patent process include (1) a latch mechanism that allows the use of existing, vertically-oriented soil samplers in a horizontal borehole and (2) a sampler capable of taking multiple samples along the borehole in a single operation.

A recent development called the Sampler Emplacement System was developed to enhance the capabilities of the hybrid directional boring machinery. The system takes samples while drilling.

- Drill Cuttings Containment System (DCCS)

SNL is in the process of purchasing the prototype DCCS, which was adapted from existing commercial products according to SNL specifications. Tests were completed on the unit at SNL and WHO. The system, used for containment of contaminated drill cuttings produced while air drilling, is capable of vacuuming and filtering a wide range of materials. SNL's Environmental Drilling Projects Group initiated the DCCS project to improve containment of cuttings at hazardous waste sites. Guzzler Manufacturing, Inc. built the prototype machine, which was demonstrated at SNL in 1993. One prototype exists, and although Guzzler Manufacturing is capable of building duplicate units, they currently have no plans to do so.

- Cross Borehole Electromagnetic Imaging (EM Imaging)

The SNL PI transferred this technology to the commercial partners, RIMtech and Raytheon Nevada Services. These companies have obtained outside service contract work 
based on the technology developed and demonstrated at the MWLID, which can be used to map the subsurface of a site by measuring the attenuation and phase shift of radio frequency signals propagated between boreholes. Several surveys have been conducted at SNL's CWL: a 3-D survey of the 60s Pits utilizing transmitters in the two slant boreholes and the receiver roving the surface (1993); borehole-to-borehole imaging of the Unlined Chromic Acid Pit (UCAP) utilizing the three UCAP wells (1992-93); and borehole-toborehole imaging utilizing a pulsed radar system (1993). A demonstration was also completed at the Kirtland Air Force Base (KAFB) Radioactive Burial-11 (RB-11) landfill. The commercial partners have obtained EM Imaging survey work based on the MWLID successes. Specific work for RMMtech and Raytheon Nevada Services includes characterization of disposal trenches at Rocky Flats (first commercial use in 1993), plume and leak detection at Fernald, enhanced oil recovery for the AMOCO Consortium, and monitoring infiltration through fractured basalt at Idaho National Engineering Laboratory (INEL). The commercial rights to the technology were sold to the Physical Science Laboratory (PSL) at NMSU in 1994. PSL is marketing the technology as the Radio Imaging Method (RIM).

- Dry Barrier Applications for Landfills

The Dry Barrier Concept developed and demonstrated at SNL through the Dry Barrier Applications for Landfills project has been incorporated into the LANL Waste Management Plan as part of a landfill liner system for the Mixed Waste Disposal Facility. A dry barrier is composed of fine material over coarse layers of geologic material. The coarse layer is dried by ambient air flow to reduce potential water migration into contaminated soil, which can create leachate. To create a dry barrier, air is circulated into the coarse layer where it accumulates water vapor as it passes through the layer and then emerges as moist air. SNL and its partners have made a substantial modification and improvement to the dry barrier concept by using a coarse layer of material that has a significant primary storage (i.e., has sufficient interconneted pore space to hold significant qualities of liquid). In this design, water that moves from the fine layer into the coarse layer is held by the primary storage of the coarse layer. Air flow through this layer can then remove the water over a much greater time than if the water was not held in the primary porosity of the coarse layer. The technology is being developed under a contractual agreement with UNM and Daniel B. Stevens and Associates. The rights to the original patent are owned by Daniel B. Stevens and Associates, which is a co-applicant with SNL for a patent on modifications to the technology.

- Magnetometer Towed Array (MTA)

GEO-CENTERS, Inc. is commercializing the services of the MTA, a rugged lowmagnetic-signature vehicle that tows a trailer containing an array of seven field magnetometers with precise satellite positioning. The system is capabable of locating and mapping buried ferrous (iron) metal-containing wastes. Analysis of maps generated with the MTA indicates size, depth, and location of objects. The MTA can survey an average of 20 acres per day up to 14 feet deep. It was successfully demonstrated at the SNL CWL and Technical Areas II (TA-2) and 3 (TA-3) and KAFB's RB-11 landfill. GEO-CENTERS conducted its first commercial survey at SNL TA-2 in 1993. Other commercial surveys have been conducted at LANL, KAFB, Aberdeen Proving Grounds, and for the Southern California Gas Company. GEO-CENTERS has several patent applications in process. 
Benefits that GEO-CENTERS gained from collaborating with SNL on the MTA included gaining knowledge and a relevant technical critique of the system. This work was partially responsible for GEO-CENTERS' decision to develop a multiple sensor system, the Surface Towed Ordnance Locator (STOLSTM), that will collect both magnetic and electromagnetic data simultaneously.

- ResonantSonic ${ }^{M}$ drilling technique

A collaboration between SNL and Water Development Corporation (a sonic drilling equipment manufacturer and contractor) resulted in a 1993 demonstration of the low-angle, slant drilling capabilities of the ResonantSonic ${ }^{\mathrm{M}}$ drilling technique. Sonic drilling allows rapid drilling without a significant waste stream and affords the opportunity to collect $100 \%$ of the core. The collaboration was designed to evaluate and improve the performance of sonic drills for slant hole drilling, which included instrumentation of the system to isolate parameters that would be used to improve system performance. Two demonstration slant boreholes were drilled beneath the SNL CWL to provide concurrent acquisition of unique time-resolved data characterizing the mechanical behavior of the sonic drilling system during operation. The demonstration was the first installation of low-angle slant boreholes for environment purposes under a waste site using sonic drilling technology. Dynamic drilling data were obtained using an instrumented subassembly newly designed by SNL. The structural element for this subassembly was manufactured by Water Development Corp. and corresponded to the uppermost section of drill pipe in the string (stinger), which mounts directly below the sonic drill head. The transducer package added at SNL included strain gages and an accelerometer. These sensors have provided developers with an understanding of forces experienced during drilling and identified failure modes.

- Alternative Landfill Cover Demonstration (ALCD)

The ALCD is facilitating regulatory acceptance by involving the Environmental Protection Agency (EPA) and environmental divisions from the western states in the ALCD. Endorsement by the WGA and the Committee to Develop On-site Innovative Technologies (DOIT), SNL is leading an effort to inaugerate interstate cooperation. The project will provide alternatives to the EPA's landfill cover designs that will work more effectively in arid climates at significant cost savings. The ALCD will coordinate input from other SNL-ERT technology development projects to provide more effective landfill cover designs. It will also oversee the testing of innovative landfill covers. These designs, along with currently required EPA cover designs, will be installed and monitored in a side-byside demonstration at SNL. The covers will be evaluated and compared based on construction, cost, and performance criteria. Performance criteria include runoff, erosion, movement through the cover, lateral drainage, change in water storage, and evapotranspiration.

- SitePlanner ${ }^{\mathrm{TM}}$

ConSolve, Inc. commercialized this object-oriented database system designed for site assessment work to integrate, manage, and display site characterization data as it is being generated. Internally, Argonne National Laboratory's (ANL's) Environmental Assessment and Information Sciences Division and Environmental Research Division have been actively using SitePlanner ${ }^{\mathrm{TM}}$ for site characterization at a variety of sponsors' sites from 1992 
through 1994. The sites include DOE's Weldon Spring, DOE's Great Plains Coal Gasification Plant, the Army's Joliet Army Ammunition Plant and Aberdeen Proving Grounds, the Air Force's Los Angeles Air Force Base, USDA food storage facility locations in Nebraska, and ANL itself. Externally, SitePlanner ${ }^{\mathrm{TM}}$ demonstrations have been given for environmental research staff from LANL, SNL, INEL, and the Army's Environmental Center (formerly USATHAMA). The first commercial use of SitePlanner ${ }^{\mathrm{TM}}$ was made at SNL's Mixed Waste Landfill (MWL) in 1992.

SitePlanner ${ }^{\mathrm{TM}}$ has been included as one of the technologies incorporated in the Expedited Site Characterization approach advocated by CMSTIP.

- PLUME

ConSolve commercialized this interactive software package developed at ANL with funding from the MWLID in May 1994. The software enables drastic reductions in costs and time required for characterization because it addresses the entire sampling strategy problem from contamination measurement to benefit assessment for more sampling to recommendation for sampling locations. PLUME's initial demonstration was conducted through MWLID field work during FY94 at SNL, where it was incorporated into the Sandia Environmental Decision Support System (SEDSS). The first commercial application of PLUME continues at Tyndale Air Force Base by Applied Research Associates. The software was commercialized through a CRADA between ANL and ConSolve. As its part of the CRADA, ANL provided code, documentation, and external verification for PLUME, while ConSolve focused on providing dynamic data exchange capabilities between PLUME and SitePlanner. In addition to commercial availability through ConSolve, PLUME is available to federal agencies through Engineering Software Transfer Center (ESTC) at ORNL. The University of Chicago owns the copyright.

- SiteView ${ }^{\mathrm{TM}}$

ConSolve has developed and is marketing a less robust version of SitePlanner ${ }^{\mathrm{TM}}$ called SiteView ${ }^{\mathrm{TM}}$ as an inexpensive, easy way to create $3-\mathrm{D}$ visualizations of environmental data on Pentium-based computers. SiteView ${ }^{\mathrm{TM}}$ combines object-oriented data manipulation with features that allow users to integrate, analyze, and view complex spatially referenced data. For example, SiteView ${ }^{\mathrm{TM}}$ can display topographic and planimetric maps; contamination plumes in air, soil, and water; subsurface stratigraphy and groundwater flow information; and the relationship of contamination to topographical and operations data.

\section{Stripping Analysis}

The PNL PI for Stripping Analysis is working with Radiometer America Corporation to develop process manuals to commercialize with the analytical equipment that is used to determine the concentrations of leachable chromium, lead, cadmium, copper, nickel, zinc, and cobalt on soils and sediments, and to identify underground source plumes underlying chemical and mixed waste landfills. The first commercial use of this Stripping Analysis technology determined concentrations of leachable chromium at SNL CWL in 1992. It has also been demonstrated at WHO and Elison Air Force Base. PNL, the NMSU Department of Chemistry, and Radiometer Corp. are collaborating on this technology. No patents or copyrights exist. 
- X-ray Fluorescence Spectroscopy (XRF)

$\mathrm{XRF}$, a system used to detect and quantify inorganic contamination in soils above the water table using a photoelectric process, is expected to be commercialized by 1996 after the demonstration of the final prototype. PNL and Scitek developed this technology. The prototype probe was demonstrated at SNL in September 1993. PNL and Scitek are working on this project under a CRADA signed in 1993. The PNL PI has developed a commercialization plan.

\section{Pending Technology Transfer/Commercialization (as of FY95)}

Pending Technology Transfers/Commercializations include the following seven technologies:

- Electrokinetics

To continue research and development of electrokinetics, the SNL-ERT has contracted with NMSU to determine its marketing potential. The electrokinetic program at SNL has been extending electrokinetic remediation technology to unsaturated soils. This technology is intended to provide a method for in situ removal of anionic (negatively charged) heavy metal contaminants from unsaturated soils. For the MWLID, this included chromium, which is one of the contaminants of interest in the SNL CWL UCAP. Although this technology has not yet been transferred, the SNL PI has developed a commercialization plan.

- Multi-sensor Analysis Program for Environmental Restoration (MAPER)

Commercialization of MAPER, which was demonstrated as part of the Thermal Enhanced Vapor Extraction System (TEVES) and Landfill Assessment and Monitoring System (LAMS) projects, is being directed by the SNL-ERT. MAPER is a software package for analysis of waste site geophysical characterization data. It utilizes all geophysical site data to produce an optimal estimate of the distribution of buried material. The data fusion is achieved through a joint optimization algorithm: the buried material estimate is obtained as a weighted average of the observation residuals from each sensor type. The development of MAPER is supported by the DOE OST through the Cross-Cutting and Advanced Technology Program, MWLID, and WERC.

- Sandia Environmental Decision Support System (SEDSS)

A license is pending for the SEDSS. A system prototype will be developed into an operational version in FY95. The system is designed to extend the application of risk-based performance assessment methodologies to environmental restoration and waste management activities. This problem-solving approach explicitly accommodates uncertainty while integrating risk analysis with data collection. The SEDSS prototype is being developed to link numerous probability-based analysis tools in a user-friendly computer-based environment. SitePlanner ${ }^{\mathrm{TM}}$ and PLUME, OST-developed software, have been linked to the SEDSS prototype. Eventually, the system will provide the user with a mechanism for making and substantiating decisions based on either (1) a level of 
confidence in the environmental restoration or waste management path that should be taken or (2) the feasibility of the associated costs of the various zions. IITRI is commercializing this technology.

- Thermal Enhanced Vapor Extraction System (TEVES)

Transfer is pending for the TEVES, which combines two soil heating methods (resistive and dielectric) with a vacuum vapor extraction system and an off-gas treatment system SNL and the Illinois Institute of Technology Research Institute (IITRI) are developing the system. An SNL-ER demonstration was conducted at the CWL for the remediation of VOCs. IITRI is commercializing the technology through Groundwater Technology. Groundwater Technology is actively pursuing commercial applications of TEVES.

- Environmental Measurement-While-Drilling System (EMWD)

A commercially available EMWD System will be marketed in 1997 if the system is shown to be technically and economically feasible. A field implementation of the full system at a radioactive/mixed waste site is scheduled for April 1996. In an EMWD, downhole sensors are located behind the drill bit and linked by a high-speed data transmission system to a computer at the surface. As a borehole is created, data are collected on the nature and extent of contamination, enabling on-the-spot decisions to be made regarding drilling and sampling strategies. Preliminary field tests have been conducted at the CMW directional boring test site, the radioactive calibration facility at Grants, NM, and at SNL. Although this technology has not yet been transferred, a commercialization plan has been developed.

- Borehole Tension Permeameter

The pump and pressure monitoring components of the Borehole Tension Permeameter system are planned for commercial release. This system infiltrates (i.e., slowly adds) water into soil under unsaturated soil conditions to provide data suitable for hydraulic conductivity and estimates near ambient soil moisture conditions. Depending on funding, further development of the packer system and'porous pads will evolve around materials selection software. Three years of development are anticipated for full capabilities, including a syringe pump system, packer system, below water table capability, and software development. The system has been demonstrated at INEL. Although this technology has not yet been transferred, the PI has developed a commercialization plan.

- Crosswell Seismic Imaging

Licensing is pending for Crosswell Seismic Imaging, a technology that provides a means to image the geology between boreholes. The information provides understanding of contaminant transport and selection of the best remediation methods. Field

demonstrations have shown good correlation of imaged velocities with geology interpreted from well logs. The technology can be used at a wide variety of sites and in conjunction with several different remediation processes. Seismic imaging can be used at any site where information on geology between boreholes is necessary. It can also be used for monitoring any remediation technology that significantly changes the seismic properties of the subsurface. DOE, SNL, and Richard Hills own the patent on the Advanced Downhole 
Periodic Seismic Generator. Although this technology has not yet been transferred, the PI has developed a commercialization plan.

\section{International Technology Transfer/Commercialization Successes (as of FY95)}

Further development of technology transfer and commercialization opportunities of mature technologies with international businesses could benefit the DOE cleanup mission and the U.S. environmental management industry. Already the SNL-ERT has experienced success in the international arena. The following six SNL-ERT-developed technologies have been demonstrated or used commercially internationally:

- SEAMISTTM

SEAMISTTM has been demonstrated for an international audience and has received international press. Companies from Germany, China, Taiwan, and Mexico have shown an interest. Eastman Cherrington Environmental has had sufficient interest from Taiwan that they have applied for a Taiwanese patent. An installation in Mexico is also probable.

- Hybrid Directional Boring

CMW has demonstrated the hybrid directional boring equipment for the national and international DITCHWITCH ${ }^{T M}$ franchises. Additionally, the equipment was demonstrated at an international construction trade show, Bauma 195, in München, Germany in April 1995. CMW is confident that the hybrid directional boring technology will be used internationally.

- Cross Borehole Electromagnetic Imaging (EM Imaging)

EM Imaging technology has been demonstrated internationally to the mining and oil industries and is now being used in Australia, Canada, Russia, and Spain by these industries. The commercial rights to the technology were purchased in 1994 by PSL at NMSU. The laboratory is working with Raton Technology Research to access the national and international environmental markets. The technology is being marketed as the Radio Imaging Method (RIM).

- Magnetometer Towed Array (MTA)

GEO-CENTERS has conducted a series of successful demonstrations in Germany with a man-portable version of the Surface Towed Ordnance Locator System (STOLSTM) (i.e, MTA), which was commercialized in the U.S. in 1993. GEO-CENTERS has also recently completed two international agreements. It has entered into a licensing agreement with Entsorgungs und Sanierungstecknik $\mathrm{GmbH}$ (E.S.T.), a wholly owned subsidiary of Deutsche Aerospace, Germany, to provide equipment, manpower, and training.

It has entered a parallel agreement with Schiebel Electronics, Austria, to jointly develop and market new sensors for the STOLSTM. Under this agreement, GEO-CENTERS will provide the target analysis software. GEO-CENTERS will serve as the U.S. representative for this jointly developed technology. 
- SitePlanner ${ }^{\mathrm{TM}}$

The SitePlanner ${ }^{\mathrm{TM}}$ software has been internationally commercialized by ConSolve. The software is currently used in Australia and Korea. ConSolve is seeking a distributor for the European market.

- SiteView ${ }^{\mathrm{TM}}$

More than 100 copies of ConSolve's less robust version of SitePlanner ${ }^{\mathrm{TM}}$ called SiteView ${ }^{\mathrm{TM}}$ have been sold internationally. 


\section{REGULATORY INVOLVEMENT}

Technologies developed under the MWLID, and presently under the new DOE Focus Area structure, must gain regulatory acceptance to ensure that proven technologies are transferred for government and private sector use. Key concerns of the SNL-ERT include shortening permitting time, reducing permitting costs, minimizing duplicate and unnecessarily sequential requirements, increasing deployment, obtaining interstate cooperation, increasing the number of technologies being permitted, and achieving faster commercialization. A fundamental step toward eliminating these concerns is to establish credible, two-way relationships and methods of communication between technology developers and regulators early in the process of development, demonstration, testing, and evaluation. The SNL-ERT and MWLID TIP have fostered regulatory involvement by participating in the Resource Conservation Recovery Act (RCRA) Research, Development, and Demonstration (RD\&D) permitting process and in the WGA's Committee for Developing On-site Innovative Technologies (DOIT) activities, including the Sandia Site Implementation Team (SSIT). Regulators have also participated as members of the Technical Support Groups which perform technology evaluations and recommend new development projects for funding.

\section{Research, Development, and Demonstration Permits}

The MWLID assisted in obtaining RCRA permits for the field demonstration of remediation technologies. The Strategy for Mixed Waste Landfill Integrated Demonstration: $A$ Roadmap, 1991, presents the MWLID's strategy for collaborating with the SNL-Environmental Restoration to demonstrate developing environmental technologies at the CWL and MWL and transfer successfully demonstrated technologies for full-scale application at these sites. RD\&D permitting activities in FY94 and FY95 included obtaining permits for demonstrations of two technologies: TEVES, Electrokinetic Remediation of Chromium from Unsaturated Soil, and (in FY96) the In-Situ Gaseous Reduction System (IGRS) demonstration.

\section{Thermal Enhanced Vapor Extraction System (TEVES)}

The MWLID PI submitted a permit application and was granted an RD\&D permit in November 1994 to conduct VOC remediation at the CWL using TEVES. The TIP assisted with the public comment stage of this permit application. This was the first RD\&D permit application submitted to and awarded by the NMED.

\section{Electrokinetic Remediation of Chromium from Unsaturated Soil}

The Electrokinetics project applied for an RD\&D permit to conduct a chromium remediation process using electrokinetics. Based on response to the application by the NMED, the application was revised to include involvement of the EPA's SITE program and to provide 
further definition of the experimental design based on clean field test results. The permit was granted July 18, 1995 and went into effect August 17, 1995.

\section{In-Situ Gaseous Reduction System}

The first draft of the permit application for a demonstration of the IGRS for reduction of chromium has been completed and is being reviewed.

\section{Western Governors' Association}

Environmental representatives from ten western states and the EPA reviewed the Test Plan for the ALCD and provided feedback regarding the demonstration. This participation illustrates the successes of the ALCD and WGA in facilitating regulatory approval by increasing involvement of federal and state regulators. The ALCD PI, TIP PI, and the WGA intitiated regulatory and stakeholder involvement in 1994. The WGA is also initiating interstate cooperation to hasten acceptance of innovative technologies among states. Environmental regulators involved in the ALCD represent New Mexico, Texas, Nevada, Washington, Arizona, Nebraska, Utah, California, Idaho, Colorado, EPA Regions 6 and 8, and EPA Headquarters. Gaining regulatory approval also hastens public acceptance. Stakeholder contacts such as meetings, tours, and videos began in June 1995 and continued through August 1995 when the ALCD Phase I construction was completed. (See page 34, "Western Governors Association - DOIT Activities, " for more information). Phase II construction will occur in 1996 at which time data on cost and constructability will be collected for inclusion in a report on these uses. Perfomance data for both phases will be collected and reported periodically over the next five years.

All funding for the research, design, construction, and testing of the landfill designs is being provided by the OST. However, through the support of the WGA, the NMED is working with the TIP to facilitate the interstate cooperation and stakeholder involvement processes. This ongoing effort began in 1993 when the WGA introduced a legal agreement among the states that would allow interstate acceptance of innovative technologies.

Involving regulators throughout the ALCD project will facilitate the acceptance of alternative designs for closure consideration. These covers will provide increased performance for arid sites at a significant cost savings. Obtaining an interstate cooperation agreement could also save thousands of dollars for each project because the permitting process would be simplified. 


\section{PUBLIC RELATIONS}

Developing good public relations is essential for facilitating public and regulatory and stakeholder acceptance of innovative technologies. TIP uses press releases to inform both the technical and popular audiences. These press releases have generated significant interest, as evidenced by the extent of electronic media coverage and publications. Media coverage serves as a conduit to public participation.

\section{Media Coverage}

The MWLID TIP initiated, facilitated, and assisted the staging and writing of nine news releases, 21 external publications, 20 internal publications, and 6 broadcasts on either radio or television. A reference list of these events appears in Appendix D.

\section{Awards}

SNL-ERT efforts have gained significant exposure through outside recognition. In September 1994, SEAMIST ${ }^{\text {TM }}$ received an R\&D 100 Award for Technical Excellence. The R\&D Awards, an international competition, recognized the 100 most technologically significant new products of the year. The purpose of the awards is to acknowledge innovators and organizations for outstanding practical technical developments and to identify significant technological advances. Exposure included public announcement of the winners in the September 1994 issue of the RED Magazine. Winning products were also featured on major radio and television stations as well as in newspapers and trade joumals.

In 1994, the International Association for Computer Methods and Advances in Geomechanics award John Stormont, PI for Dry Barrier Applications for Landfills, the Young Researcher Outstanding Contribution to Consituative Model Applications. The award recognized the paper "Prediction of Dialation and Permeability Changes in Rock Salt," J. Stormont, I. Daemen, and C. Desai, International Journal of Numerical and Analytical Methods in Geomechanics, vol. 16, pp. 545-569, 1992.

TIP's general technology transfer efforts have also gained recognition. In November 1994, TIP's technology transfer efforts for the former MWLID received an honorable mention from the Federal Laboratory Consortium's Annual Award for Excellence in Technology Transfer. 
This Page Intentionally Left Blank 


\section{PUBLIC PARTICIPATION}

One method used to measure the MWLID/SNL-ERT's success is by quantifying the number of developed technologies that have been transferred to private industry. Innovative technologies must obtain public, industry, and regulatory approval. A fundamental step toward approval is to establish credible two-way relationships and methods of communication between technology developers and stakeholders early in the process of development, demonstration, testing, and evaluation. A list of meetings that fostered relationships between technology developers and stakeholders can be found in Appendix I. Interfacing with stakeholders is necessary to achieve greater acceptance of innovative technologies, avoid obstruction and litigation during cleanup activities, and hasten technology transfer to the private sector. The TIP has fostered stakeholder involvement by drafting a public participation plan, participating in the Sandia Public Involvement Working Group (SPIWG) and WGA DOIT activities like the Sandia Site Implementation Team (SSIT), attending workshops that provide training in public participation methods, and promoting its projects through conferences and poster presentations.

\section{Public Participation Plan}

The Public Participation Plan for the MWLID was drafted with the intent of assuring meaningful public participation using quality principles to meet stakeholder needs and continually improve the methods used to address their concerns. The plan identifies members of the public who represent the culturally, ethnically, and racially diverse population living near SNL. Key groups identified include the Mountainview Advisory Council, the East Manzano Alliance, the Southwest Organizing Project, the Southwest Research and Information Center, All People's Coalition, the Albuquerque for Center for Peace and Justice, Citizens for Alternatives to Radioactive Dumping , the Albuquerque Chamber of Commerce, several specific businesses, and regulators. Key concerns of the public include the environmental impact of past, present, and future SNL hazardous waste practices; location and progression of radioactive and chemical waste streams; priorities for environmental restoration; and formation of a site-specific advisory board. To address these concerns, the Public Participation Plan outlines five tasks:

1. Create a forum for the public to provide input.

2. Listen to that input and assure the public that their input was heard.

3. Take action on the public input.

4. Communicate back to the public on the response to their input.

5. Work with the public to continually improve the process.

The TIP takes action on these tasks by working as part of the SPIWG, the DOE/SNL Community Relations Team (CoRe), and the SSIT of the WGA Mixed Waste Working Group. These organizations seek to develop a climate of trust and partnership with the public in order 
to identify, discuss, and resolve environmental, safety, health, cultural, social, and economic issues.

The SSIT stakeholder involvement with the ALCD project exemplifies the TIP's attention to completing the tasks designated in the Public Participation Plan. Public participation efforts for the ALCD began by identifying interested members of the public and regulatory community and providing copies of the ALCD design (Task 1). These people reviewed the plan and suggested changes to the design to meet their particular concerns (Task 2). The SSIT then evaluated the suggested changes for the ALCD and implemented feasible recommendations (Task 3). Once the design was revised, the SSIT reported to the public and regulators. They identified changes made and explained why other suggestions were not included in the revision (Task 4). To continue to improve public and regulatory involvement, the SSIT holds regular meetings (Task 5).

\section{Western Governor's Association - DOIT Activities}

The Federal Advisory Committee for Developing On-site Innovative Technologies for Environmental Restoration and Waste Management (DOIT) was created in 1992 to accelerate cleanup efforts at federal waste sites. Specific objectives include:

- establishment of a partnership to coordinate clean-up efforts at federal waste sites;

- implementation of improved methods resulting in faster and cheaper development, deployment, evaluation, and commercialization of innovative technologies;

- identification of demonstration sites; and

- improvement in stakeholder involvement, technology permitting, procurement, and dissemination of results.

The DOIT committee consists of federal and state members, including four western governors; the secretaries of the DOD, Department of the Interior (DOI), and DOE; the Administrator of the EPA, and ex-officio members from the Office of Management and Budget (OMB) and the WGA. The committee aims to meet its objectives by involving local community representatives in demonstration projects by seeking their input on the implementation, progress, and results of a demonstration. It also strives to improve management and regulatory approval by encouraging site managers and federal and state regulators to review their methods, resulting in more effective demonstrations and faster release of evaluation results. The committee integrates ongoing work using Working Groups that identified regional innovative demonstration sites. At these sites, representatives from government agencies, business, and environmental groups will work as a team with site personnel.

SNL and TIP personnel are involved in the WGA DOIT Committee through their service on the SSTT, whose members are listed in Appendix J. In addition, the ALCD project has been selected by the Mixed Waste DOIT Working Group as one of the innovative technologies the committee is endorsing. 
The principal investigator of the ALCD and the TIP identified the following benefits gained from MWLID/SNL-ERT's participation in the WGA:

- Regulatory involvement.

- Reviews have gained favorable publicity for MWLID/SNL-ERT projects.

- Increased exposure of MWLID/SNL-ERT and ALCD throughout the western states and country.

- Requests for help and advice are made weekly from investigators of other landfill cover projects.

- A large increase in the number of technology contacts made since participating with the WGA.

\section{Sandia Site Implementation Team (SSIT)}

Three SNL and TIP representatives serve on the SSIT for the Mixed Waste DOIT Working Group. Other members include representatives from the WGA Mixed Waste Working Group, the State of New Mexico, NMED, WERC, the Sierra Club, the Southwest Research and Information Center, RE/SPEC, Inc., and Isleta Pueblo.

The purpose of a site implementation team is to facilitate the demonstration of a proven technology by providing political, regulatory, and public approval and financial assistance when possible. To meet their objectives, the SSIT has held a number of meetings to develop a dialogue among actively interested stakeholders in the design and implementation of the Sandia Site Implementation Plan (SSIP) and to build links with existing stakeholder involvement activities at the site. A copy of the plan for stakeholder participation can be found in Appendix $\mathrm{K}$.

The SSIT has successfully incorporated public involvement with the ALCD. The SSIP defines three SSIT goals for the ALCD. In addition to the technical goal (testing, evaluating, and comparing alternative landfill covers for application at semi-arid/arid landfill sites) the SSIP defines regulatory and stakeholder goals that focus on improving technology transfer.

The SSIT intends to achieve the regulatory goal (providing a basis for comparison to regulators in anticipation that successful alternatives may gain regulatory acceptance) by completing six tasks outlined in the SSIP:

1. Develop criteria by which the success of the regulatory goal will be evaluated.

2. Identify appropriate state and federal regulatory experts and request their participation in plan design.

3. Incorporate regulator recommendations into the plan design.

4. Communicate with appropriate state and federal experts about the demonstration's development and results.

5. Assist the EPA in incorporating demonstration results into their national landfill cover model.

6. Evaluate whether the regulatory component of the demonstration meets the success criteria set forth. 
The SSIT must address regulatory approval because the EPA and state regulators do not currently accept the use of alternative landfill covers. This lack of acceptance hinders development and implementation of innovative technologies, which may be more effective than current systems. The ALCD intends to demonstrate the effectiveness of innovative cover systems compared to currently accepted cover systems. The SSIT has determined that the best way to transfer successful covers technologies is to gain the acceptance of regulators and to incorporate information into EPA's technology guidance documents concerning landfill covers. The regulatory barrier will be overcome by allowing regulators to review the test plan, which will make them familiar with the demonstration. The SSIT will also incorporate regulator concerns into the design and keep them informed of the demonstration's progress. These steps are necessary because familiarity with the technologies will make regulators more inclined to permit their use.

The ALCD and TIP PIs and the WGA intitiated regulatory and stakeholder involvement in 1994. Environmental representatives from ten western states and the EPA have reviewed the test plan for the ALCD and have provided feedback regarding the demonstration. The WGA is also initiating interstate cooperation to hasten acceptance of innovative technologies between states. Environmental regulators involved in the ALCD represent New Mexico, Texas, Nevada, Washington, Arizona, Nebraska, Utah, California, Idaho, Colorado, EPA Regions 6 and 8, and EPA Headquarters.

The SSIT intends to achieve the stakeholder goal (i.e., develop a dialogue among actively interested stakeholders in the design and implementation of the SSIP and build linkages with existing stakeholder involvement activities at the site) by completing four tasks outlined in the SSIP:

1. Develop criteria to determine the effectiveness of stakeholder involvement.

2. Develop a process through which the criteria can be measured and assessed.

3. Implement the processes in conjunction with the other elements of the demonstration.

4. Evaluate whether the stakeholder element of the demonstration follows the success criteria established.

These tasks have been designed to achieve community participation and confidence because stakeholder involvement is essential to validate the demonstration and transfer process. This participation will lead to greater acceptance and will avoid obstruction and litigation during cleanup.

Stakeholder contacts such as meetings, tours, and videos began in June 1995 and ended in August 1995, when the ALCD Phase I construction occurred. In November 1995, testing and evaluation of Phase I began. Phase II construction will occur in the summer of 1996. Data on. comparitive issues, cost constructability, and performance data will be included in an upcoming report.

An initial mailing to identify stakeholders and determine their interests was sent in mid-April 1995. As of May 9, 1995, 192 of 1028 questionaires had been returned. (Appendix L 
summarizes the responses to the questionaire.) Based on the initial responses, an information seminar and a site tour were scheduled.

A WGA-DOIT SIT Stakeholder meeting was held for the ALCD in June 1995. The purpose of this meeting was to focus on public involvement and interstate regulatory cooperation. The meeting was attended by about 70 technical, regulatory and public stakeholders from several southwestern states. The morning session included introductory remarks by Garry King, DOIT Mixed Waste Working Group Chair, and Ginger Swartz, DOIT Process Administrator for WGA. The session also included a presentation on the ALCD by Steve Dwyer, the PI.

The format of the afternoon session was a panel discussion on technical, regulatory, and public issues. Panelists included regulators from the EPA and the New Mexico Environment Department; technical, academic and industry experts; and public stakeholders. The participants' general consensus was that this was a good first step, with many of the comments focusing on global regulatory and public interface issues. The project was seen in a very positive light by technical, regulatory, and public stakeholders. Questions were raised on how the project would aid regulators and the regulated communities, the effectiveness of alternative covers, cost-benefit analysis, and public access to information. Follow-on meetings included a planned site tour during the construction phase of the project.

Stakeholders visited SNL's Tech Area III on September 12, 1995 for the ALCD Open House to evaluate Phase I of the ALCD. Phase II of the ALCD will test and evaluate several innovative cover designs.

The Phase I portion of the five-year project consists of three model landfill sites measuring 300 feet by 40 feet that are currently under construction. These sites replicate three landfill cover types: a RCRA-standard municipal landfill site cover (Subtitle D); a RCRAsanctioned hazardous waste landfill cover (Subtitle C); and an alternative hazardous waste landfill cover. The alternative design uses a manufactured geosynthetic clay liner (GCL) instead of the natural two-foot clay liner stipulated by the RCRA guidelines. The GCL is engineered to block water passage more effectively than a natural clay layer. During the demonstration, the GCL's performance will be gauged against the RCRA standard.

Summaries of the Open House Evaluations were distributed to members of the ALCD Team. An Update was written for the stakeholders and distributed by November 30, 1995. A copy of Steve Dwyer's presentation at the Open House and a notice of the draft design plan availability were distributed with the Update. The focus of the Update was on answers to frequently asked questions (see Appendix L). Examples include queries about vegetation, compressibility of materials, and costs. The team members agreed that some of these issues would not be addressed in this demonstration and it was necessary to make this point clear to the stakeholders. It was also noted that some of the information requested was not currently available.

A final report of WGA-DOIT activities for Phase I of the ALCD will be submitted by the SSIT to the Mixed Waste Working Group by January 31, 1996. The final report will discuss the initial parameters for the ALCD, including a description of the technology, the site, and the existing outreach with stakeholders and/or regulators. The final report will include the 
evaluations returned by the participants of the June 29, 1995 stakeholder meeting and the September 12, 1995 Open House. These evaluations will help the ALCD Team assess the demonstration enhancements.

\section{Community Leaders Workshop}

The Community Leaders Project was designed to create a network of community leaders at both the national and site levels who are knowledgeable about and interested in OST activities. Recommendations for the best ways to form this group were solicited at a February 1993 workshop. Input from this meeting was used to design a second workshop.

The second Community Leaders Workshop, sponsored by the DOE and Urban Energy \& Transportation Corporation, was held in Augusta, GA in August 1993. The specific objective of the workshop was the development of a public involvement process that encourages successful implementation of innovative cleanup technologies at contaminated sites.

The workshop was attended by approximately 40 community, advocacy, and business leaders as well as state and local environment department representatives. The participants were mainly from the states of Georgia, Idaho, North Carolina, New Mexico, Ohio, and Washington. Leaders from these locations were invited because of the integrated demonstrations that are operated at DOE sites in these states. New Mexico attendees included Don Kawal, president-elect of the Albuquerque Chamber of Commerce; Richard Brusuelas of the Bernalillo County Environmental Health Department; Paul Robinson of Southwest Research; Ray Sisneros of the Santa Fe Public Works Department; and Cecelia V. Williams of the SNL-ERT, TIP. This workshop focused on the VOCs in Non-Arid Soils Integrated Demonstration, at Savannah River and review of the OST's Strategic Plan (pre-decisional draft) and the Public Participation Plan.

\section{Public Participation Planning and Training Workshops}

A Public Participation Planning and Training Workshop was organized to teach managers of EM programs how to incorporate public participation into their management framework. The two-day course, which was still in the prototypic stage, was given by Creighton \& Creighton, Inc., the organization responsible for the public involvement successes of the Bonnyville Power Authority. The course had four objectives:

- to understand public participation and why it is necessary,

- to learn a thought process for analyzing decisions and developing public participation plans,

- to know how to work through the strategic analysis and public participation planning process, and

- to gain experience working with a public participation planning team. 
Attendees included more than 30 employees and contractors. Involved in the class were representatives from DOE/HQ Public Affairs, who are coordinating a DOE-wide effort among Assistant Secretaries to develop and implement a DOE policy on public participation. Four representatives from SNL attended the workshop: Jennifer Nelson, Cecelia V. Williams, Grace Bujewski, and Steve Baca.

All SNL representatives attending the course found it useful. Lessons taught a way of interacting, thinking, and listening that allows scientists and engineers to address and satisfy the needs of the public. Specific lessons focused on methods of understanding the public, facilitating public meetings, and overcoming obstacles by listening and action.

\section{Information Exchange}

The SNL-ERT and the TIP have also participated in a number of conferences and other activities by poster exhibition, presentation, or participation to promote public awareness and interest in their innovative technologies. The interest generated at these conferences has been substantial and has led to many specific contacts for several of DOE's OST technologies. These interactions have resulted in over 250 contacts with potential technology developers and users. These contacts span the environmental arena from EM-40 to other federal government agencies, state agencies, Native American agencies, and private industry. The conferences and other activities are described in Appendix $\mathrm{E}$. 
This Page Intentionally Left Blank 


\section{EVALUATION OF TECHNOLOGY TRANSFER/ COMMERCIALIZATION ACTIVITIES}

The OST has defined metrics to measure the success of technology transfer/ commercialization efforts. The MWLID/SNL-ERT has since FY91 met or exceeded these metrics with success through funding 30 technical TTPs, which have resulted in 15 technology transfer/commercialization successes and another eight pending successes. The SNL-ERT will continue MWLID's technology transfer/commercialization efforts through the completion of a market analysis to identify technologies with the most potential for technology transfer/commercialization.

To evaluate MWLID's previous and SNL-ERT's continuing efforts, metrics have been defined for measuring technology transfer successes. The success of the MWLID/SNL-ERT is measured by the use of successfully demonstrated technologies for the cleanup of the DOE complex and by technology transfer to private industry. Information on these technology transfer/commercialization successes, including idenitification of technologies available for licensing, will then be packaged and disseminated. The products and technologies either transferred for use at DOE facilities and/or commercialized for private sector use are:

- Electrokinetics (pending)

- MAPER (pending)

- Troxler 4350 probe for Advanced In Situ Moisture Logging

- SEAMISTMM

- MultiScan ${ }^{\mathrm{TM}}$

- Pipe Explorer ${ }^{\mathrm{TM}}$

- Hybrid Directional Boring Machinery

- Drill Cuttings Containment System

- Thermal Enhanced Vapor Extraction System (pending)

- Cross Borehole Electromagnetic Imaging

- Dry Barrier Applications for Landfills

- Magnetometer Towed Array (MTA)/Surface Towed Ordnance Locator System (STOLSTM)

- Resonant Sonic ${ }^{5 M}$ drilling techrique

- Alternative Landfill Cover Demonstration (pending)

- Sandia Environmental Decision Support System (pending)

- Environmental Measurement-While-Drilling System (pending)

- SitePlanner ${ }^{\mathrm{TM}}$

- PLUME

- SiteView ${ }^{\mathrm{TM}}$

- Borehole Tension Permeameter (pending)

- Stripping Analysis

- Crosswell Seismic Imaging (pending)

- X-Ray Fluorescence Spectroscopy

These successes have brought notable attention to the OST. For example, SEAMISTMM was selected for a 1994 R\&D 100 Award for Technical Excellence. Another project, the ALCD, is making strides in establishing interstate cooperation by working with the WGA and EPA. 
The MWLID/SNL-ERT has been following the performance measures (or metrics) for technology development identified by the OST. The metrics and the MWLID/SNL-ERT parallel achievements are as summarized in Table 3.

\section{Table 3. OST Metrics and Associated MWLID/SNL-ERT Achievements}

\begin{tabular}{|c|c|}
\hline OST Metric & MWLID/SNL-ERT Achievement \\
\hline $\begin{array}{l}\text { Identify "Improved Technologies" (those } \\
\text { showing improvement over baseline } \\
\text { technologies) that lower cost, reduce risk } \\
\text { to workers and the public, and provide a } \\
\text { cleaner final site. }\end{array}$ & $\begin{array}{l}\text { The SNL-ERT's technologies have reduced the number of boreholes } \\
\text { and samples needed for site characterization. There were } 60 \text { field } \\
\text { demonstrations of these technologies thattresulted in no personal } \\
\text { injuries or exposures. No releases or episodes have placed the } \\
\text { public or the environment at risk. The concept of identifying and } \\
\text { then remediating the fastest constituents and containing the } \\
\text { remaining contaminants will allow for a cleaner final site with } \\
\text { reduced costs compared to conventional remediation. }\end{array}$ \\
\hline $\begin{array}{l}\text { Develop technologies that meet } \\
\text { engineering and economic criteria after } \\
\text { bench and pilot phases. }\end{array}$ & $\begin{array}{l}\text { The MWLID demonstrated several technologies that derived from } \\
\text { the In-Situ remediation Intergrated Program (ISRIP), and the SNL- } \\
\text { ERT will demonstrate another technology in FY95. }\end{array}$ \\
\hline $\begin{array}{l}\text { It is essential to have user involvement in } \\
\text { the development process. }\end{array}$ & $\begin{array}{l}\text { The MWLID and the SNL-ERT have and will continue to work with } \\
\text { the SNL-ER in identifying needs and evaluating new proposals. The } \\
\text { MWLID has field tested technologies on SNL-ER sites to assist in } \\
\text { characterization and partial remediation of hazardous landfills. }\end{array}$ \\
\hline $\begin{array}{l}\text { Assure availability of technologies for } \\
\text { transfer with full documentation, and } \\
\text { ensure they meet the requirements of } \\
\text { stakeholders. }\end{array}$ & $\begin{array}{l}\text { The MWLID/SNL-ERT has worked with OST Headquarters Program } \\
\text { Managers and Operations Office Program personnel in identifying } \\
\text { deliverables and milestones, writing final reports, and conducting } \\
\text { commercialization workshops to ensure that transfer of technologies } \\
\text { can be completed smoothly and efficiently. The MWLID beta-tested } \\
\text { ProTech, a technology database, and was instrumental in collecting } \\
\text { information for it. }\end{array}$ \\
\hline $\begin{array}{l}\text { Technologies must meet the requirements. } \\
\text { of stakeholders and final decision } \\
\text { documents. }\end{array}$ & $\begin{array}{l}\text { Stakeholders were constantly informed about the progress of } \\
\text { MWLID technology development through technology reviews, mid- } \\
\text { year reviews, and technical reviews for future funded projects. The } \\
\text { OST also includes stakeholders in its mid-year reviews and } \\
\text { publishes monthly status reports. The SNL-ERT will continue to } \\
\text { provide a forum for stakeholders. }\end{array}$ \\
\hline $\begin{array}{l}\text { Provide mechanisms for private sector } \\
\text { industries to use their creativity and } \\
\text { entrepreneurial spirit. Pull together the } \\
\text { best talent and innovation available, } \\
\text { leverage DOE dollars with private } \\
\text { investment, and improve technology } \\
\text { transfer and implementation. }\end{array}$ & $\begin{array}{l}\text { The MWLID had } 25 \text { industrial partners, } 7 \text { national laboratories, } 4 \\
\text { research laboratories, and } 6 \text { universities working together on FY94 } \\
\text { projects. In addition, two CRADAs were in place. In FY95, the SNL- } \\
\text { ERT has } 8 \text { industrial partners, } 7 \text { national laboratories, } 4 \text { research } \\
\text { laboratories, and } 4 \text { universities working on technical projects. } \\
\text { WERC has also been very active on several different technology } \\
\text { demonstrations. Leveraging of over } \$ 1 \text { million OST funding with } \\
\text { industry partners support has reinforced the SNL-ERT's commitment } \\
\text { to leverage current industry funds to develop technologies to fullfill } \\
\text { the OST mission. To ensure that technologies are transferred, the } \\
\text { MWLID conducted commerialization workshops to aid the private } \\
\text { sector in marketing technologies. Small business workshops have } \\
\text { also been conducted to help private sector businesses understand } \\
\text { the ways they can partner with the national laboratories. }\end{array}$ \\
\hline
\end{tabular}




\section{SUMMARY}

Fifteen technologies or products have been successfully transferred and/or commercialized through the Mixed Waste Landfill Integrated Demonstration (MWLID). Presently, through the Landfill Stabilization Focus Area and the Contaminant Plume Containment and Remediation (Plume) Focus Area, another eight technology transfer/commercialization successes are pending. These successes have brought notable attention to the DOE Office of Science and Technology (OST). These successes have shown that OST's goals of hastening the transfer of innovative technologies and achieving commercialization of promising technologies are possible. Additionally, we have assisted in the materials development and technology transfer activities for SNL-CMST Cross Cutting Program Technologies. The transfer of three products (1) Fiber Optic Relative Humidity Sensor, (2) Time Domain Reflectometry (TDR) Sensor for determining soil moisture content, both for the Cone Penetrometer and (3) Flow Probe Chemical Analyzer, is pending.

The Technology Integration Project has met OST's goals by involving industry in technology development and commercialization, gathering and disseminating information about MWLID/SNL-ERT activities and technologies, and promoting stakeholder and regulatory involvement. Industry collaborations enriched the technology development and commercialization process by combining the expertise, ideas, resources, and experience of both the national laboratories and industry. Development and dissemination of materials provided a means to show how industry and laboratory collaboration improve the design and implementation of innovative technologies. Media exposure, poster displays, technology summaries, and other documents help allay stakeholder apprehensions and hasten regulatory approval. Fostering stakeholder and regulatory involvement is important to achieve support of innovative technologies. Specifically, regulatory acceptance is essential to speed the permitting process, decrease regulatory costs, and increase the number of new technologies deployed.

MWLID technologies has been reassigned to the Landfill Stabilization and Plume Focus Areas. The SNL Environmental Restoration Technologies (ERT) Department is now directing the development, transfer, and commercialization of technologies which were formerly part of the MWLID. The TIP is continuing the technology transfer/commercialization activities of the MWLID. One MWLID activity continued by the SNL-ERT is the conduct of a market analysis for promising technologies. Such work will provide a focus for future technology transfer/commercialization efforts. 
This Page Intentionally Left Blank 


\section{Appendix A}

Sources of Information 
This Page Intentionally Left Blank 


\section{Sources of Information}

Bertram-Howery, S. G., S. M. Howarth, J. M. Phelan, J.C. Stormont, and L.D. Tyler. 1991. Strategy for the Mixed-Waste Landfill Integrated Demonstration: A Roadmap. Albuquerque, NM: Sandia National Laboratories.

Sarah M. Hayes, Andrea R. Pistone, Cecelia V. Williams, Final Report for the Small Business Workshop, Sandia National Laboratories and Los Alamos National Laboratories, Albuquerque, NM, October 26, 1993.

Letter from Roger Layne, Charles Machine Works, Inc., to Hazel O'Leary, Secretary of Energy, December 1994.

Jeffrey M. Lenhert, Comments from Working Lunch at Environmental Bottom Line, DOE/AOO memorandum to Joseph Paladino, August 12, 1993.

Jeffrey M.Lenhert, Monthly Status Report on the Regional Small Business Workshop Albuquerque, DOE/AOO memorandum to Joseph Paladino, September 9, 1993.

Rudy Mataluccie, Charlene Esparza-Baca, Richard Jimenez, and Scott Hitchcock, Status and Export Potential of DOE's Mixed Waste Landfill Integrated Demonstration (MWLID) Technologies, Sandia National Laboratories, Albuquerque, NM, February 17, 1995 (draft).

New Database May Help Firms Get Federal Jobs, Albuquerque Joumal, November 7, 1994, Sec. Business Outlook, p. 22.

Andrea R. Pistone, Industry Workshop Summary from Los Alamos and Sandia National Laboratories, Los Alamos National Laboratory memorandum to Joseph Paladino, December 8, 1993.

Nancy Prindle, Field Days, Sandia National Laboratories memorandum to Field Tours Team, May 22, 1993.

Nancy Hayden Prindle, Cecelia Williams, and Dr. Estelle Zannes, Technology Integration Plan for the Mixed Waste Landfill Integrated Demonstration at Sandia National Laboratories, Sandia National Laboratories, Albuquerque, NM, August 30, 1993.

Prospective Technology (ProTech) Communication System: Information for Environmental Cleanup, Battelle Seattle Reserach Center fact sheet.

Protech: Technologies of Tommorrow, Battelle Seattle Research Center brochure.

PTS Program Manager's Report for ADS/TTP \#: AL-2241-01 WBS \#: 1.5.3.1.2.4, Reporting Periods 10/93 through 9/94. 
Radio Imaging Method, RIM, Physical Sciences Laboratory brochure, New Mexico State University.

SNL Demonstrates Mixed Waste Landfill Technologies, Tie Quarterly, Fall 1994, p. 15.

Cecelia Williams and Thomas Burford, An Overview of the Mixed Waste Landfill Integrated Demonstration, Fourth Annual WERC Environmental Restoration Conference held in Las Cruces, NM, May 1994.

Cecelia Williams and Thomas Burford, Technology Development Opportunities in the MWLID, Fourth Annual WERC Environmental Restoration Conference held in Las Cruces, NM, May 1994.

Cecelia Williams and Thomas Burford, The Mixed Waste Landfill Integrated Demonstration: Metrics for Technology Development and Technology Transfer Successes, Federal Environmental Restoration III and Waste Minimization II, held in New Orleans, LA, May 1994.

Letter from Joan Woodward, Director of Environmental Programs of Sandia National Laboratories, to Dr. Clyde W. Frank, EM-50 DAS for Technology Development, 1995.

ALCD Site Implementation Team, Demonstration Implementation Plan for the Alternative Landfill Cover Demonstration, Sandia National Laboratories and State of New Mexico Energy, Minerals and Natural Resources Department, Albuquerque, NM, Fall 1994.

Sharla G. Bertram-Howery, Susan M. Howarth, James M. Phelan, John C. Stormont, and Lynn D. Tyler, Strategy for the Mixed-Waste Landfill Integrated Demonstration: A Roadmap, Sandia National Laboratories, Albuquerque, NM, September 12,1991.

Development of Hybrid Cost-Effective Directional Drilling Equipment, Sandia National Laboratories and Charles Machine Works brochure.

Author(s), An Overview of the Mixed Waste Landfill Integrated Demonstration, Nuclear and Hazardous Waste Management International Topical Meeting, held in Atlanta, GA, August 14 - 18, 1994, American Nuclear Society, Inc., La Grange Park, IL, 1994.

(See also Appendix C) 


\section{Appendix B}

\section{Survey of EM50-funded TTPs}


This Page Intentionally Left Blank 
SURVEY OF EM50-FUNDED TTPS

\begin{tabular}{|c|c|c|c|c|c|c|c|c|}
\hline TITLE & TTP NO. & $\begin{array}{l}\text { HO OFFICE, INTEGRATED } \\
\text { DEMONSTRATION, } \\
\text { PROGRAM, OR } \\
\text { RESPONSIBLE DIVISION } \\
\end{array}$ & $\begin{array}{l}\text { 1ST YR. } \\
\text { FUNDED }\end{array}$ & $\begin{array}{l}\text { LAST YR. } \\
\text { FUNDED }\end{array}$ & PAINCIPAL INVESTIGATOR & TELEPHONE NO. & STATUS & $\begin{array}{l}\text { STILL FUNDED BY EM50, } \\
\text { OTHER SOURCE, OR DROPPED }\end{array}$ \\
\hline WEAPON DISASSEMELY WASTE MINIMIZATION & AL211307 & DOTE & 1991 & $1993 \mid t$ & AL SKINROOD & FTS 234.2501 & $\begin{array}{l}\text { Could not liack } \\
\text { him down }\end{array}$ & \\
\hline 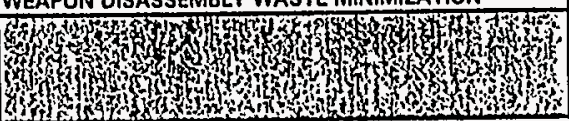 & 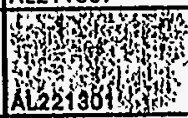 & 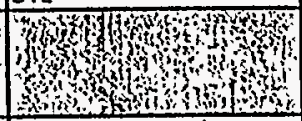 & 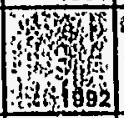 & (3) & 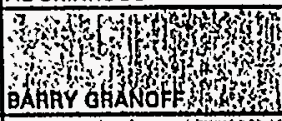 & 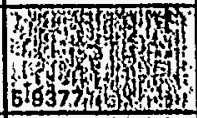 & 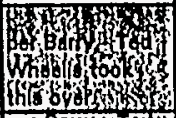 & 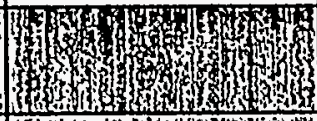 \\
\hline 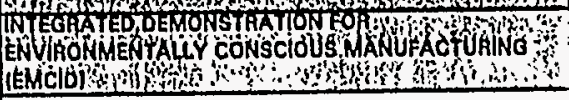 & 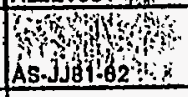 & $\begin{array}{l}\text { Why } \\
\text { RODOTE }\end{array}$ & 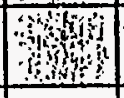 & 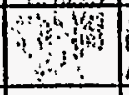 & 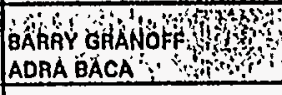 & 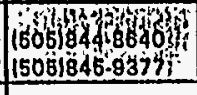 & 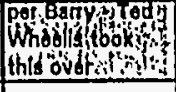 & 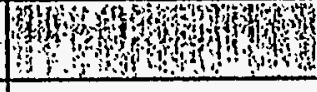 \\
\hline $\begin{array}{l}\text { LASER-SPARK SPECTROSCOPY FOR CONTINUOUS } \\
\text { METAL EMISSIONS MONITORING }\end{array}$ & AL333501 & $\begin{array}{l}\text { RD } \\
\text { OTD }\end{array}$ & 1993 & $\begin{array}{l}1995 \text { OR } \\
1996\end{array}$ & BILL FLOWEA & $(510) 294-2046$ & & YES \\
\hline DESIGN MODELS FOR SUPERCRITICAL WATER (CA) & AL342001 & DTE & 1994 & 1994 & BRENT HAROLDSEN & $(510) 294.2590$ & & same as AL342005 \\
\hline $\begin{array}{l}\text { SCWO BENCH SCALE PLATELET REACTOR } \\
\text { DEMONSTRATION PROJECT ICAI }\end{array}$ & AL342005 & DTE & 1994] & 1995 & BRENT HAROLOSEN & $\{510) 294.2590$ & & yos \\
\hline INVESTMENT CASTING OF PLUTONIUM & AL.NEWPN & DTE & & & $\begin{array}{l}\text { BIRIAN DAMKROGER, } \\
\text { FRANK J. ZANNER, } \\
\text { OENNIS PFEIFFER }\end{array}$ & $\begin{array}{|lc|}\text { FTS } & 844.7073 \\
\text { FTS } & 844.7073 \\
\text { FTS } & 844.7769 \\
\end{array}$ & & $\begin{array}{l}\text { little/no funding por Frank } \\
\text { Zanner }\end{array}$ \\
\hline SUBSURFACE BARRIER EMPLACEMENT DEVELOPMENT & AL231004 & LTE & 1993 & 1994 & BRIAN OWYER & $1505) 845.9894$ & $\begin{array}{l}\text { omitted por } \\
\text { Cocollia Williams }\end{array}$ & \\
\hline $\begin{array}{l}\text { SUPERCRITICAL FLUIDS TO REPLACE VOC CLEANING } \\
\text { MEDIA: FUNDAMENTAL PROPERTIES }\end{array}$ & ALNEWZE & DTE & & & CAROL ADKINS & $(505) 845.9119$ & & not funded \\
\hline \multirow[t]{2}{*}{ TECH INTEGRATION FOR MWLLO } & AL221109 & & & & CECELIA WILLIAMS & & $\begin{array}{l}\text { no technology } \\
\text { dov. }\end{array}$ & \\
\hline & AL.234105 & & 1993 & & CECELIA WILLIAMS & & $\begin{array}{l}\text { no technology } \\
\text { dev. }\end{array}$ & \\
\hline $\begin{array}{l}\text { VADOSE ZONE CHARACTERIZATION \& MONITORING } \\
\text { SYSTEM }\end{array}$ & AL221115 & DTE & 1992 & 1995 & 5 CECELIA WILLIAMS & (505)844.4261 & & still partially funded by EM50 \\
\hline
\end{tabular}


SUAVEY OF EMGO.FUNDED TTPS

\begin{tabular}{|c|c|c|c|c|c|c|c|c|}
\hline TITLE & TTP NO. & $\begin{array}{l}\text { HO OFFICE, INTEGRATED } \\
\text { DEMONSTRATION, } \\
\text { PROGRAM, OR } \\
\text { RESPONSIBLE DIVISION } \\
\end{array}$ & $\begin{array}{l}\text { IST YR. } \\
\text { FUNOED }\end{array}$ & $\begin{array}{l}\text { LAST YR. } \\
\text { FUNDED } \\
\end{array}$ & PPINGIPAL INVESTIOATOR & TELEPHONE NO. & status & $\begin{array}{l}\text { STILL FUNDED BY EMEO, } \\
\text { OTHER SOURCE. OR DROPPED }\end{array}$ \\
\hline ENIVROTRADE INFORMATION SYSTEM & AL223302 & ED & 1992 & 19967 & CHARLENE HARLAN & 15051844.8164 & & yos \\
\hline ROBOTICS BURIED WASTE & AL213202 & SUPPORT TECHNOLOGIES & 1991 & 1993 & DAN HORSCHEL & \begin{tabular}{|l} 
Frs 846.6329, \\
844.5827 \\
845.9836 \\
\end{tabular} & $\begin{array}{l}\text { soe omill } \\
\text { pintout of } \\
\text { technologios } \\
\text { from Scott } \\
\text { Slozak } \\
\text { seo emain }\end{array}$ & \\
\hline ROBOTICS CONTAINMENT AUTO & AL213203 & & & & DAN HORSCHEL & & \begin{tabular}{|l} 
sea emal \\
printout of \\
tochnologios \\
itom Scott \\
slozak
\end{tabular} & \\
\hline $\begin{array}{l}\text { ROBOTICS TECHNOLOGY DEVELOPMENT PROGRAM } \\
\text { SNL }\end{array}$ & AL213204 & BDO & 1991 & 1994 & DAN HORSCHEL & $1505) 846.9836$ & $\begin{array}{l}\text { printout of } \\
\text { tecthnologios } \\
\text { srom Scoot } \\
\text { Slozak }\end{array}$ & \\
\hline ROBOTICS WASTE FACILITIES OPERATIONS & AL213205 & Ps & 1991 & 1993 & DAN HORSCHEL & \begin{tabular}{|l}
844.5827 \\
845.9836 \\
\end{tabular} & \begin{tabular}{|l} 
sea emall \\
pintout of \\
tochnologilos \\
trom Scolt \\
Slozak
\end{tabular} & \\
\hline HOBOTICS R\&D & AL223201 & ps & 1992 & 1993 & DAN HOASCHEL & \begin{tabular}{|l}
$844-5827$ \\
$845 \cdot 9836$ \\
\end{tabular} & 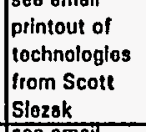 & \\
\hline & AL232007 & & 1993 & & DAN HORSCHEL & & \begin{tabular}{|l} 
sea emali \\
printout or \\
sechnologites \\
from Scoit \\
Slezak
\end{tabular} & \\
\hline Rosotics & AL233201 & & & & DAN HORSCHEL & & $\begin{array}{l}\text { surntout of } \\
\text { sechnologles } \\
\text { rom Scott } \\
\text { Slozok }\end{array}$ & \\
\hline HOBOTICS STORAGE TANKS - EAST & AL238201 & & & & DAN HORSCHEL & & 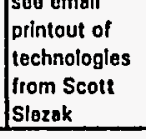 & \\
\hline
\end{tabular}




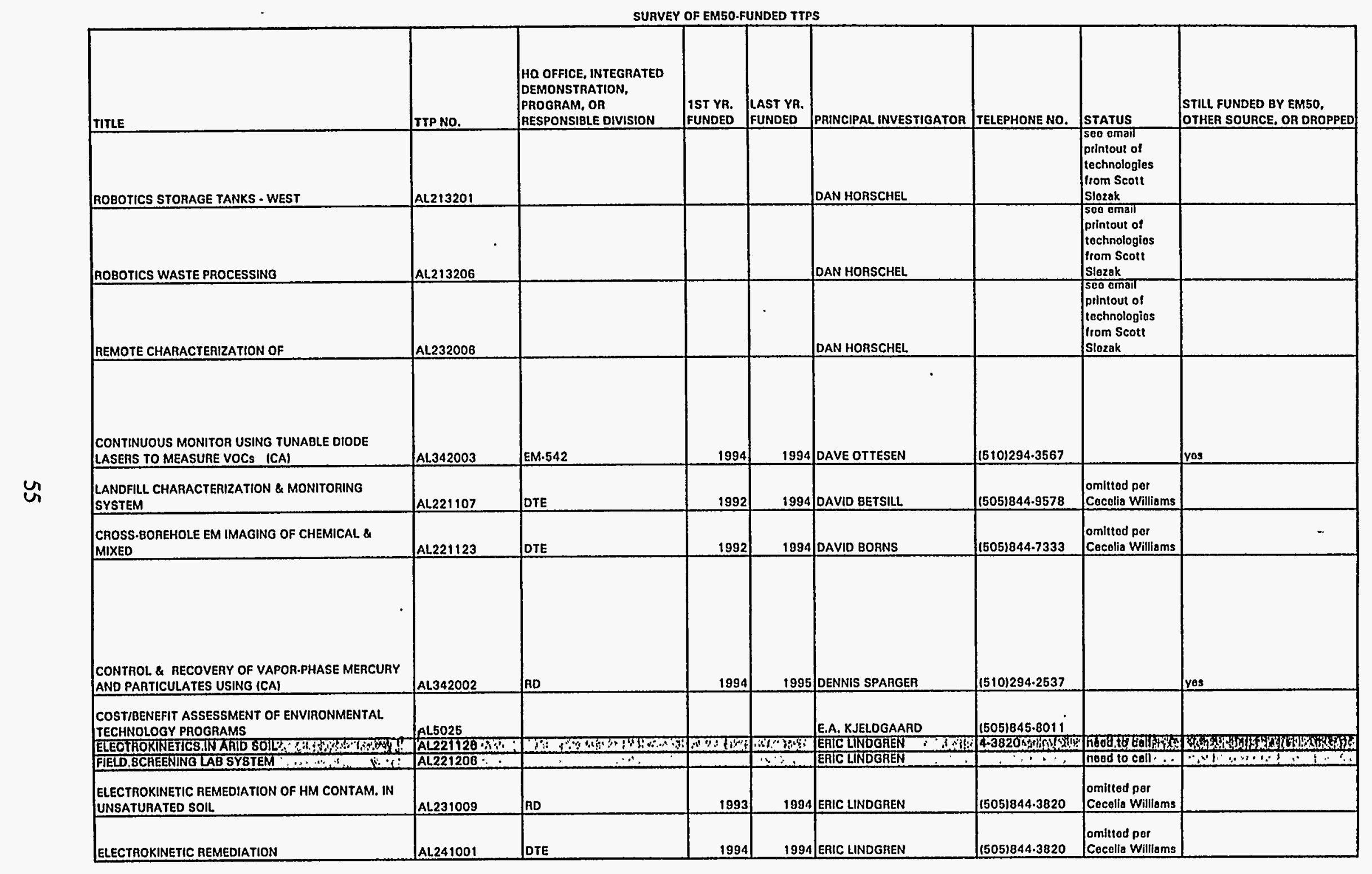


SURVEY OF EMGO.FUNDED TTPS

\begin{tabular}{|c|c|c|c|c|c|c|c|c|}
\hline TITLE & TTP NO. & $\begin{array}{l}\text { HO OFFICE, INTEGRATED } \\
\text { DEMONSTRATION. } \\
\text { PROGRAM, OR } \\
\text { RESPONSIBLE DIVISION } \\
\end{array}$ & $\begin{array}{l}\text { 1ST YR. } \\
\text { FUNDED }\end{array}$ & $\begin{array}{l}\text { LAST YA. } \\
\text { FUNDED } \\
\end{array}$ & PRINCIPAL INVESTIGATOR & TELEPHONE NO. & STATUS & $\begin{array}{l}\text { STILL, FUNDED BY EM5O, } \\
\text { OTHER SOURCE, OR DROPPED }\end{array}$ \\
\hline FLUXLESS SOLDERING TO REDUCE SOLVENT USE & AL-MF11.60 & RD & 90 & 93 & F. MICHAEL HOSKING & (505)844.4925 & & no \\
\hline INTEGRATED ENVIRONMENTALLY COMP & $A L 201302$ & & & & F. MICHAEL HOSKING & & & $\begin{array}{l}\text { Comblnod with ALMF1 1.60 pos } \\
\text { Michael Hosking; soe suiver }\end{array}$ \\
\hline RECYCLINO OF URANIUM ALLOY MACHINING CHIPS & 3279 & WMIN & & & FRANK J. ZANNER & $(605) 844.7073$ & & Zanner \\
\hline LEAD-FREE SOLDER PASTE & AL233005 & & 1993 & 1993 & $\begin{array}{l}\text { FREO YOST } \\
\text { SUSAN SACKINGER }\end{array}$ & $\begin{array}{l}4.5278 \\
5.8306\end{array}$ & & no \\
\hline $\begin{array}{l}\text { MINIATURIZEO CHEMICAL FLOW PROBE SENSOR } \\
\text { DEVELOPMENT }\end{array}$ & AL.241009 & FD & 1994 & 1994 & GEORGE LAGUNA & $(1505) 844.5273$ & $\begin{array}{l}\text { omittod por } \\
\text { Cocelia Williams }\end{array}$ & \\
\hline 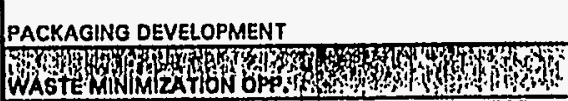 & 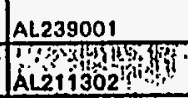 & sp & 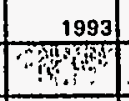 & 1994 & $\begin{array}{l}\text { GLENN HOHNSTREITER } \\
\text { GOROON SMIIT }\end{array}$ & 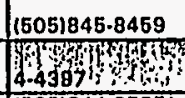 & 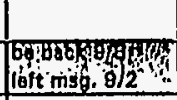 & now fundad by EM-20 \\
\hline $\begin{array}{l}\text { ON.LINE MONITORING OF VOLATILE OAGANICS FOR } \\
\text { WASTE MINIMIZATION }\end{array}$ & AL201303 & RD & 1990 & 1993 & GREG FRYE & $\begin{array}{l}15051844.07871 \\
845 \cdot 9085\end{array}$ & & succoodod by AL221104 \\
\hline $\begin{array}{l}\text { PORTABLE ACOUSTIC WAVE SENSOR (PAWS) DOWN } \\
\text { HOLE MONITORING }\end{array}$ & AL221104 & RD & 1992 & 1994 & GREG FRYE & $(505) 844.0787$ & & Iyes \\
\hline PAWS OFF.GAS & AL221102 & DTE & 1991 & 1992 & GREG FAYE & $845-9085$ & & succooded by AL221104 \\
\hline POLLUTION PREVENTION ACTIVITIES AT SNL & AL.243001 & DOTE & 1994 & 1995 & $\begin{array}{l}\text { GREG FRYE } \\
\text { CAROL ADKINS }\end{array}$ & $(505) 845.9119$ & & yes \\
\hline $\begin{array}{l}\text { CROSSWELL COMPRESSIONAL \& SHEAR WAVE } \\
\text { SEISMIC TOMOGRAPHY }\end{array}$ & AL241002 & RD & 1994 & 1994 & GREGORY ELBRING & (505)844-4904 & $\begin{array}{l}\text { omitted per } \\
\text { Cecolis Williarns }\end{array}$ & \\
\hline |INTEGRATED DEMONSTF & AL0566-AA & $\begin{array}{l}\text { IN SITU REMEDIATION } \\
\text { TECHNOLOGY }\end{array}$ & & & $\begin{array}{l}\text { GAEGORY ELIRING } \\
\text { SANFORD BALLARD } \\
\text { HARRY HARDEE }\end{array}$ & $\mid \begin{array}{l}(505) 846 \cdot 3463 \\
(505) 846 \cdot 6984 \\
(505) 844.2257\end{array}$ & & $\begin{array}{l}\text { vos- } \\
\text { undor now TTP } \\
\text { R AL241002 }\end{array}$ \\
\hline
\end{tabular}


SUAVEY OF EM5O.FUNDED TTPS

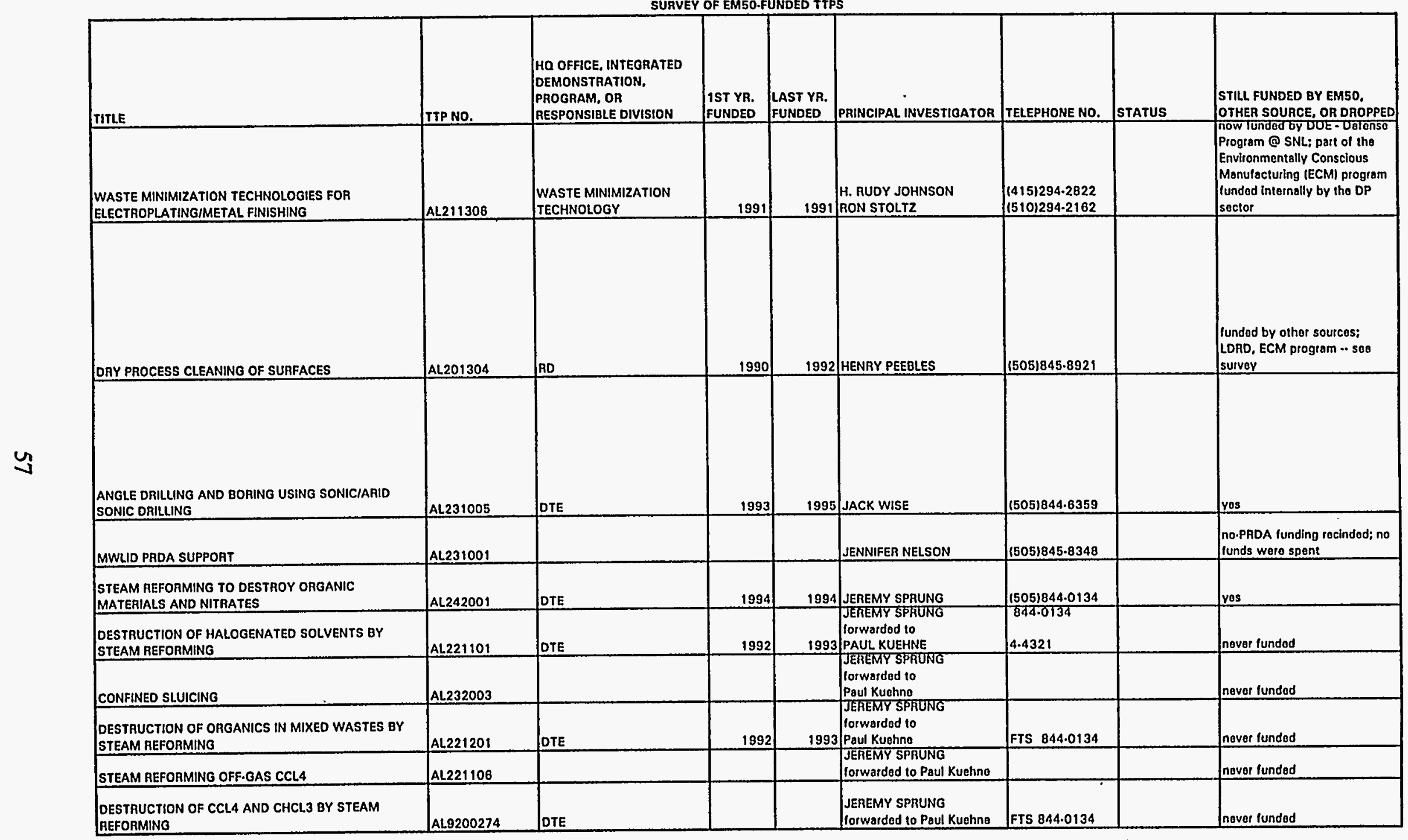




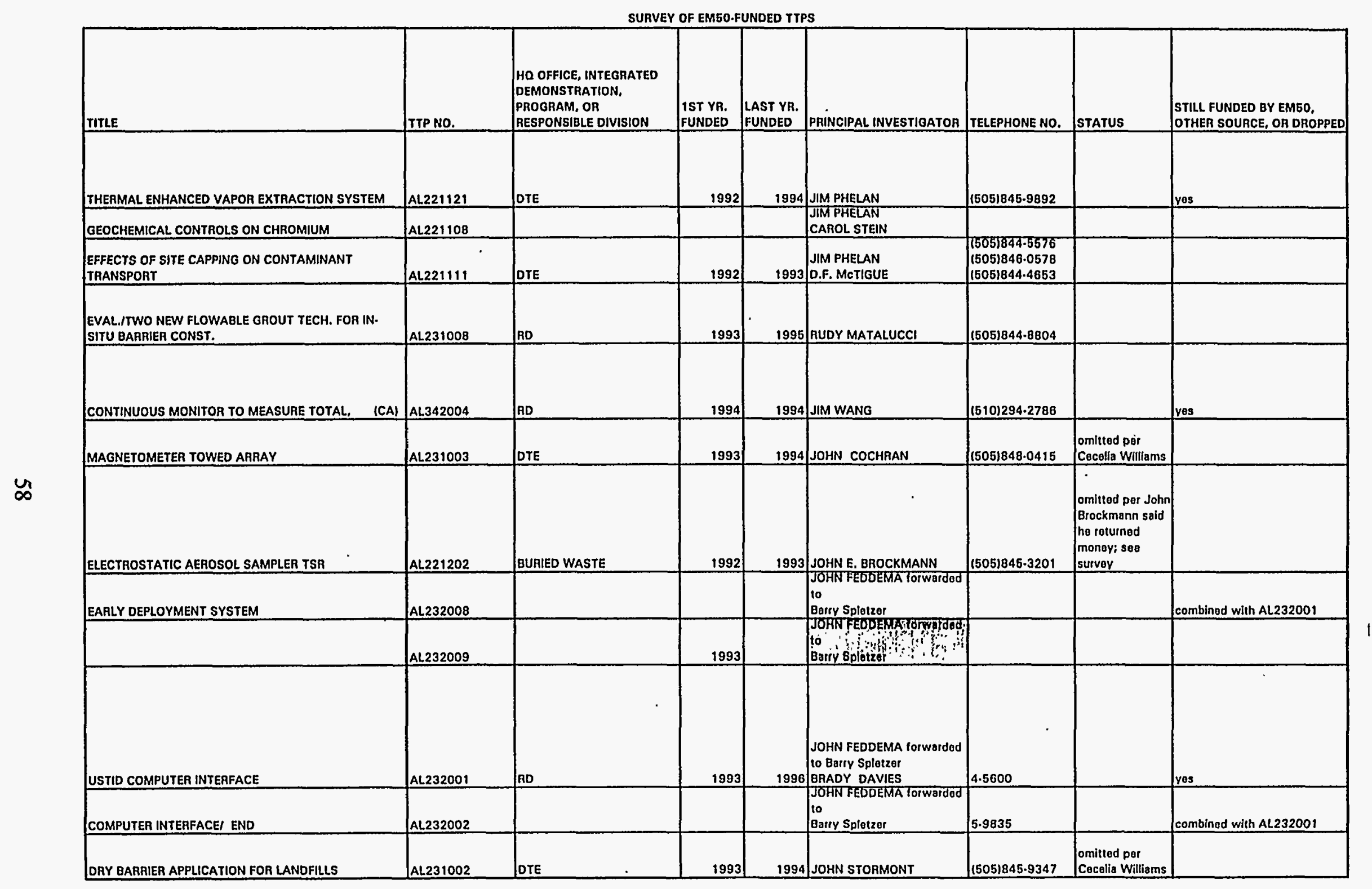


SURVEY OF EMSO.FUNDED TTPS

\begin{tabular}{|c|c|c|c|c|c|c|c|c|}
\hline TITLE & TTP NO. & $\begin{array}{l}\text { HQ OFFICE, INTEGRATED } \\
\text { DEMONSTRATION. } \\
\text { PROGRAM, OR } \\
\text { RESPONSIBLE DIVISION } \\
\end{array}$ & $\begin{array}{l}\text { 1ST YA. } \\
\text { FUNDED }\end{array}$ & $\begin{array}{l}\text { LAST YR. } \\
\text { FUNDED } \\
\end{array}$ & PRINCIPAL INVESTIGATOR & TELEPHONE NO. & Status & $\begin{array}{l}\text { STILL FUNOED BY EM5O, } \\
\text { OTHER SOURCE, OR DROPPED } \\
\end{array}$ \\
\hline $\begin{array}{l}\text { INFRARED FIBER OPTIC SPECTROSCOPY, } \\
\text { CHEMOMETRICS, AND ROBOTICS }\end{array}$ & AL4097 & ER & & & V.E. GRANSTAFF & & & $\begin{array}{l}\text { not her project per Victoria } \\
\text { Granstalf }\end{array}$ \\
\hline ADVANCED TECHNOLOGY DEVELOPMENT & AL239004 & SP & 1993 & 1994 & KEN SORENSON & 13011903.7943 & & $\begin{array}{l}\text { no - now funded through } \\
\text { EM20 }\end{array}$ \\
\hline $\begin{array}{l}\text { REPLACEMENT OF CARCINOGENS AND TOXIC } \\
\text { MATERIALS IN POLYMER PROCESSING }\end{array}$ & ALNEWZN & RD & & & $\begin{array}{l}\text { KEN WISCHMANN-retred. } \\
\text { Iorwared to } \\
\text { John Ledman }\end{array}$ & $\begin{array}{l}(505) 844.7532 \\
5.8544 \\
\end{array}$ & $\begin{array}{l}\text { Unable to locate } \\
\text { current proloct } \\
\text { loador }\end{array}$ & \\
\hline $\begin{array}{l}\text { UST AETAIEVAL, TRANSPORT AND STOAAGE } \\
\text { TECHNOLOOY CONCEPTS DEVELOPMENT } \\
\end{array}$ & AL221203 & DTE & 1992 & 1993 & LARAY BUSTARD & 845.8661 & & no \\
\hline $\begin{array}{l}\text { POLYMER-SUPPORTED CATALYTIC DETOXIFICATION OF } \\
\text { HAZARDOUS ORGANICS }\end{array}$ & 5002 & GROW & & & LAURA R. GILLIOM & 4.9104 & & $\begin{array}{l}\text { Gilliom has no recollection of } \\
\text { this project }\end{array}$ \\
\hline SOLVENT SUBSTITUTION STUDY & AL201301 & RD & 1990 & & $\begin{array}{l}\text { MICHAEL OBOANY } \\
\text { NANCY DHOOGE } \\
\end{array}$ & $\begin{array}{l}1505) 845.8040 \\
(505) 848.0883\end{array}$ & & no \\
\hline $\begin{array}{l}\text { PHOTOCATALYTICION EXCHANGE DECONTAMINATION } \\
\text { OF AQUEOUS MIXED WASTE }\end{array}$ & AL2023.1 & WASTE MANAGEMENT & 1991 & & MICHAEL PRAIRIE & $(505) 846.8109$ & & no \\
\hline CAYSTALLINE SILICOTITANATES FOR CS/SI REMOVAL & AL.232004 & AR & 1993 & 1994 & NORMAN BROWN & $(505) 845.8180$ & & yos \\
\hline ROBOTICS WASTE MIN & AL.NEWPH & SUPPORT TECHNOLOGIES & & & PAT EICKER & FTS 846.6329 & $\begin{array}{l}\text { omittod per } \\
\text { Goorgo Allon }\end{array}$ & 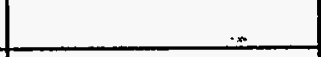 \\
\hline ROBOTICS WASTE MIN & AL-NEWPK.D & SUPPORT TECHNOLOGIES & & & PAT EICKEA & FTS 846.6329 & $\begin{array}{l}\text { Omitted por } \\
\text { George Allon }\end{array}$ & \\
\hline ROBOTICS LAB & AL.NEWPK-A & SUPPORT TECHNOLOGIES & & & PAT EICKER & FTS 846.6329 & $\begin{array}{l}\text { omltiod por } \\
\text { Goorge Allen }\end{array}$ & \\
\hline HOBOTICS AOVANCED TECHNOLOOY & AL.NEWPN & SUPPORT TECHNOLOGIES & & & PAT EICKER & FIS 846.6329 & $\begin{array}{l}\text { omituo por } \\
\text { George Allon }\end{array}$ & \\
\hline $\begin{array}{l}\text { SUPERCAITICAL. FLUIDS TO REPLACE VOC CLEANING } \\
\text { MEDIA }\end{array}$ & AL-NEWPO & SUPPORT TECHNOLOGIES & & & PAT EICKEA & FTS 846.6329 & $\begin{array}{l}\text { Omitted por } \\
\text { Goorgo Allen }\end{array}$ & \\
\hline $\begin{array}{l}\text { COST IRISK PERFORMANCE ASSESSMENT OF } \\
\text { CHARACTERIZATION TECHNOLOGIES }\end{array}$ & AL231007 & DTE & 1993 & 1994 & PAUL KAPLAN & $(505) 848.0684$ & & yes \\
\hline $\begin{array}{l}\text { WASTE MINIMIZATION-EMG } \\
\text { HOW CLEAN IS CLEAN? }\end{array}$ & AL214101 & & 1991 & 1992 & RANDY WATKINS & 15051844.3387 & & no \\
\hline HOW CLEAN IS CLEAN? & A1224102 & & 1992] & 1992 & RANDY WATKINS & $1505) 844.3387$ & & Ino \\
\hline
\end{tabular}




\begin{tabular}{|c|c|c|c|c|c|c|c|c|}
\hline 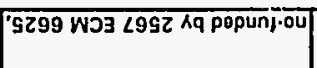 & & 67L6.9B8IGOGI & 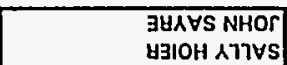 & & . & & 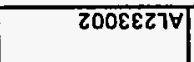 & 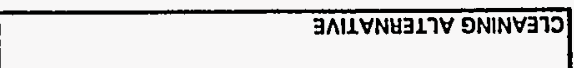 \\
\hline 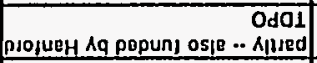 & & 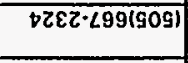 & HSUVW JI803YG 'S & 9661 & $066 !$ & 310 & 11010278 & 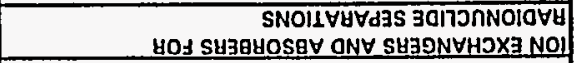 \\
\hline & & $2912 \cdot 6621019)$ & 21701S 3 Q7VNOY & 1661 & 1661 & 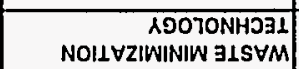 & จ०६เ1टา甘 & 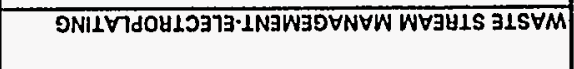 \\
\hline & 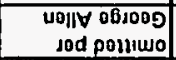 & $2268.968(909)$ & 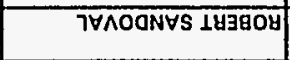 & 0661 & 8661 & ds & 6006ह27V & 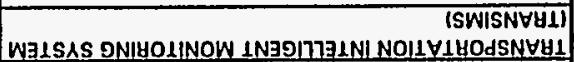 \\
\hline & 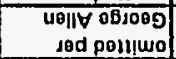 & $2768.568(909)$ & 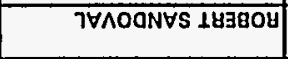 & 0661 & 8661 & dS & 8006ع27\% & $\begin{array}{r}\text { 1NBWSSBSSY } \\
\text { SWELSAS ONY NOIIVWOINY NOILYHOdSNYHI }\end{array}$ \\
\hline & 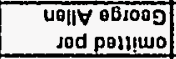 & $2268.948(909)$ & 7V & 0661 & 2661 & dS & 12002278 & DNINNVTd WJLSAS ANY TVINBWNOYIANG \\
\hline sol & & $0 \varepsilon z 2 \cdot 608(S 0 G)$ & כ7dW $3 M$ 'd $18390 \%$ & $D 661$ & 2661 & $\exists 10$ & 9111227) & 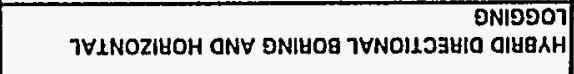 \\
\hline 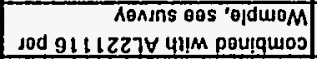 & & $0 \varepsilon z Z \cdot 6 \not 8(90 G)$ & 37dW9M 'd I8980ㅂ & $\varepsilon 661$ & 2661 & ४ต1วУบ४Hว & ह0112277 & 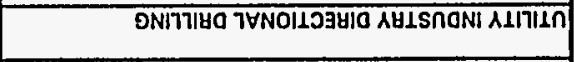 \\
\hline & 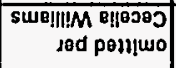 & 9260.868 (909) & NO17MONX 18980Y & 0661 & $p 661$ & वप्ष & 0101เ278 & 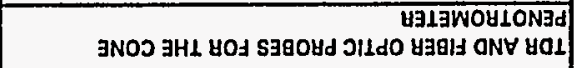 \\
\hline$\therefore$ ing & 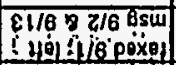 & 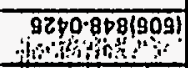 & 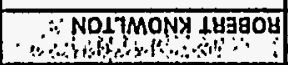 & 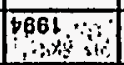 & b681. & 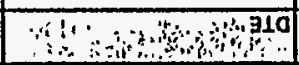 & ing & 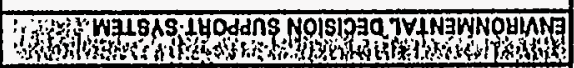 \\
\hline 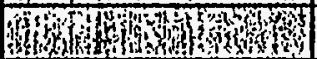 & 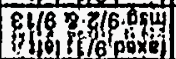 & 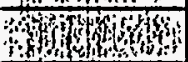 & 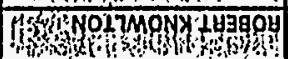 & 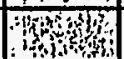 & 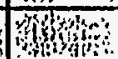 & 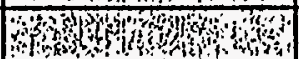 & सhets & W \\
\hline 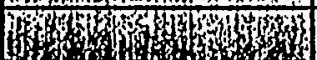 & 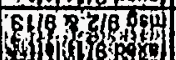 & 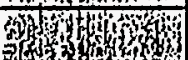 & : & Winging & sing & Noy & 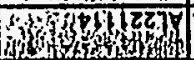 & (1) \\
\hline & 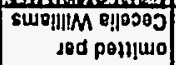 & $8929 \cdot 6+8(909)$ & NV807A 243808 & 6661 & 8661 & 310 & $\angle 001027 y$ & ONI77IYO 371HM LN \\
\hline OS- Wa Kq popuns IIIIS & & (818.9t8(S09) & $\begin{array}{r}\forall \text { OUWIHSOX } \\
\text { OUVHOIY }\end{array}$ & 9661 & $\varepsilon 661$ & $0 \mathrm{OS} \cdot \mathrm{WB}$ & 900ZEZ7V & 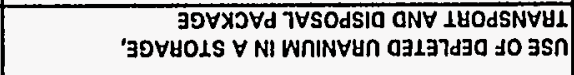 \\
\hline 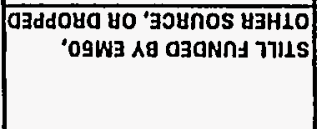 & SחLVIS & ON 3 NOHdB731 & YO1VOISISNNI JVdONIUd & 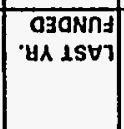 & $\begin{array}{l}\text { 03annt } \\
\text { Gh 1St }\end{array}$ & 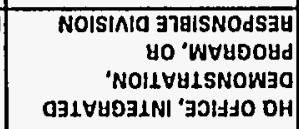 & ON AII & 3711 \\
\hline
\end{tabular}


SUAVEY OF EM5O.FUNDED TTPS

\begin{tabular}{|c|c|c|c|c|c|c|c|c|}
\hline TITLE & TTP NO. & $\begin{array}{l}\text { HQ OFFICE, NTEGRATED } \\
\text { DEMONSTRATION. } \\
\text { PROGRAM, OR } \\
\text { RESPONSIBLE DIVISION }\end{array}$ & $\begin{array}{l}\text { IST YR. } \\
\text { FUNDED } \\
\end{array}$ & $\begin{array}{l}\text { LAST YR. } \\
\text { FUNDED }\end{array}$ & PPINGIPAL INVESTIGATOR & TELEPHONE NO. & status & $\begin{array}{l}\text { NDED BY EMEO. } \\
\text { OURCE, OR DROPPED }\end{array}$ \\
\hline GROUNDWATER FLOW SENSOR/SEISMIC IMAGING & AL201101 & DTE & 1990 & 1994 & SANFORD BALLARD & 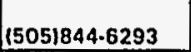 & & no \\
\hline $\begin{array}{l}\text { IN.SITU DEVICE FOR MEASUREMENT OF SOIL TENSION } \\
\text { AND SOLUTE CHEMISTAY IN THE VADOSE ZONE }\end{array}$ & 2025 & $\begin{array}{l}\text { IN SITU REMEDIATION } \\
\text { TECHNOLOGY }\end{array}$ & & & $\begin{array}{l}\text { SANFOAD BXELAAD } \\
\text { D.F. MCTIGUE } \\
\text { H.W. STOCKMAN } \\
\text { C.L. STEIN }\end{array}$ & (505)844.5576 & & no \\
\hline $\begin{array}{l}\text { A DRY FLUOAIDE VOLATLLTY PROCESS FOR NUCLEAR } \\
\text { FUEL AEPROCESSING }\end{array}$ & AL211701 & IINNOVATIVE TECHNOLOGY & 1991 & 1991 & SHERIDAN C. JOHNSTON & $\begin{array}{l}(510) 294-2138 \\
\text { FTS } 234-2138 \\
\end{array}$ & $\begin{array}{l}\text { proloct tekon } \\
\text { ovor by Rich } \\
\text { Bohrens }\end{array}$ & no \\
\hline 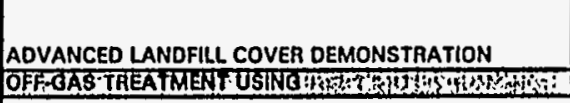 & 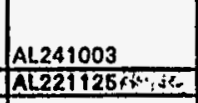 & DTE & 1994 & $\begin{array}{l}4994 \\
\end{array}$ & 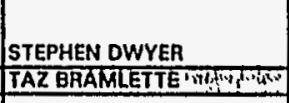 & 15051844.0595 & 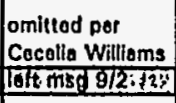 & 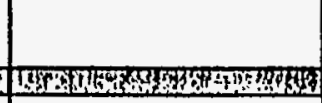 \\
\hline TOMSK EXPLOSION CHANGE DETECTION STUDY & AL 231010 & & 1993 & 1995 & TOM PREVENDER & 5.8768 & & yos \\
\hline OF URANIUM AL & 2018 & ER & & & $\begin{array}{l}\text { W.A. HARELAND } \\
\text { C.L. STEIN }\end{array}$ & $\begin{array}{l}(505) 844.7758 \\
(505) 8445578\end{array}$ & & \\
\hline 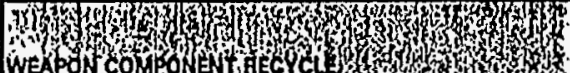 & 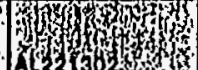 & How & (y) & Win & 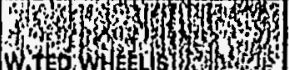 & 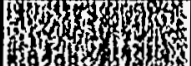 & 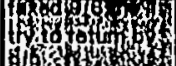 & max \\
\hline 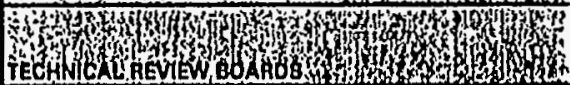 & ity & & & $\log _{4}$ & 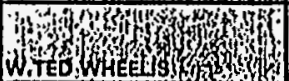 & 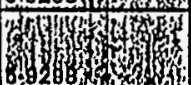 & 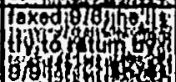 & (7) \\
\hline 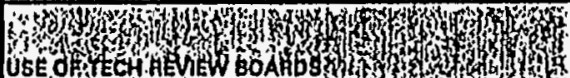 & 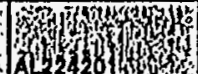 & D. & $x^{3}$ & W & Wrytow & 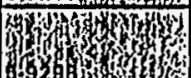 & 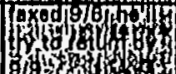 & (3) \\
\hline 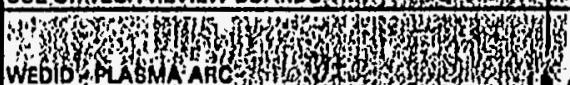 & 16 & How & mon & (4) & 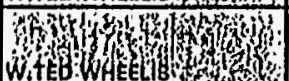 & 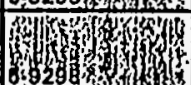 & 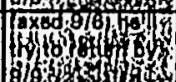 & (6) \\
\hline 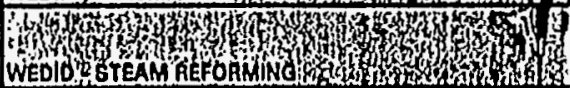 & 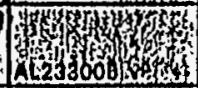 & 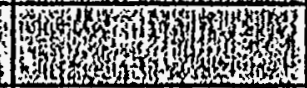 & 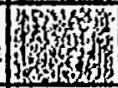 & (1) & 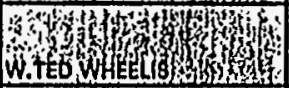 & 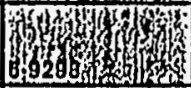 & 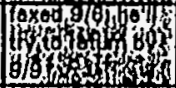 & 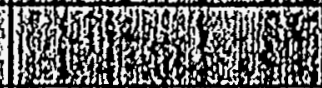 \\
\hline 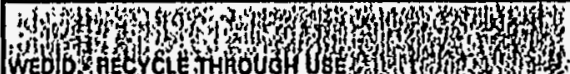 & 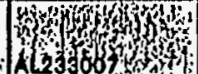 & (1) W W & Whin & Who & 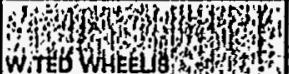 & 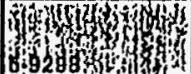 & 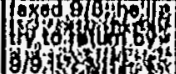 & (y) \\
\hline 3oly & whinginging & 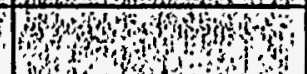 & 4his & 4 & mond & 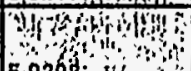 & 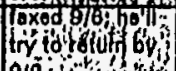 & 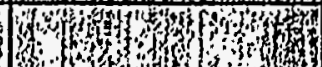 \\
\hline & & & & & & & & \\
\hline
\end{tabular}


SURVEY OF EM6O.FUNDED JTPS

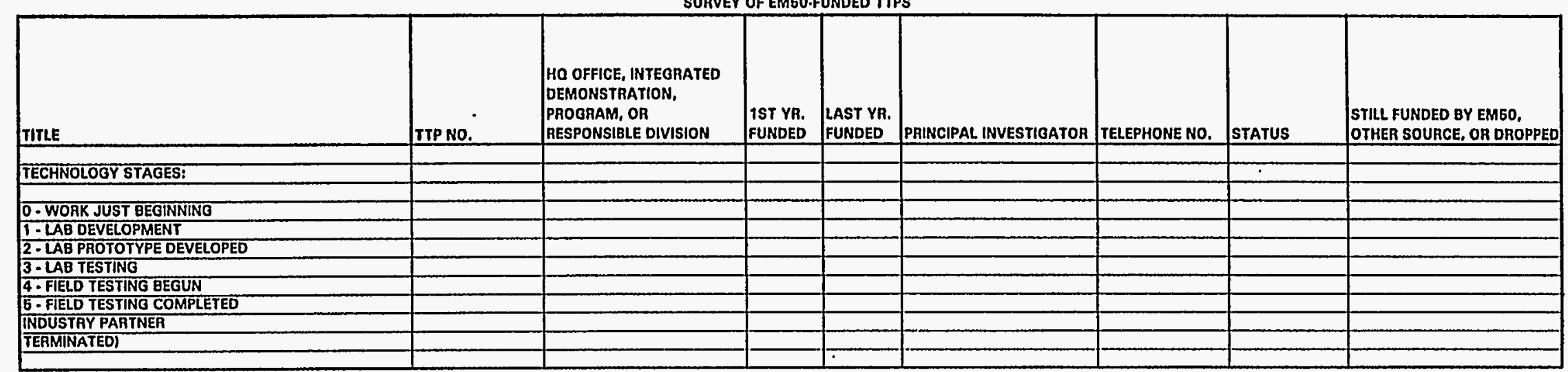




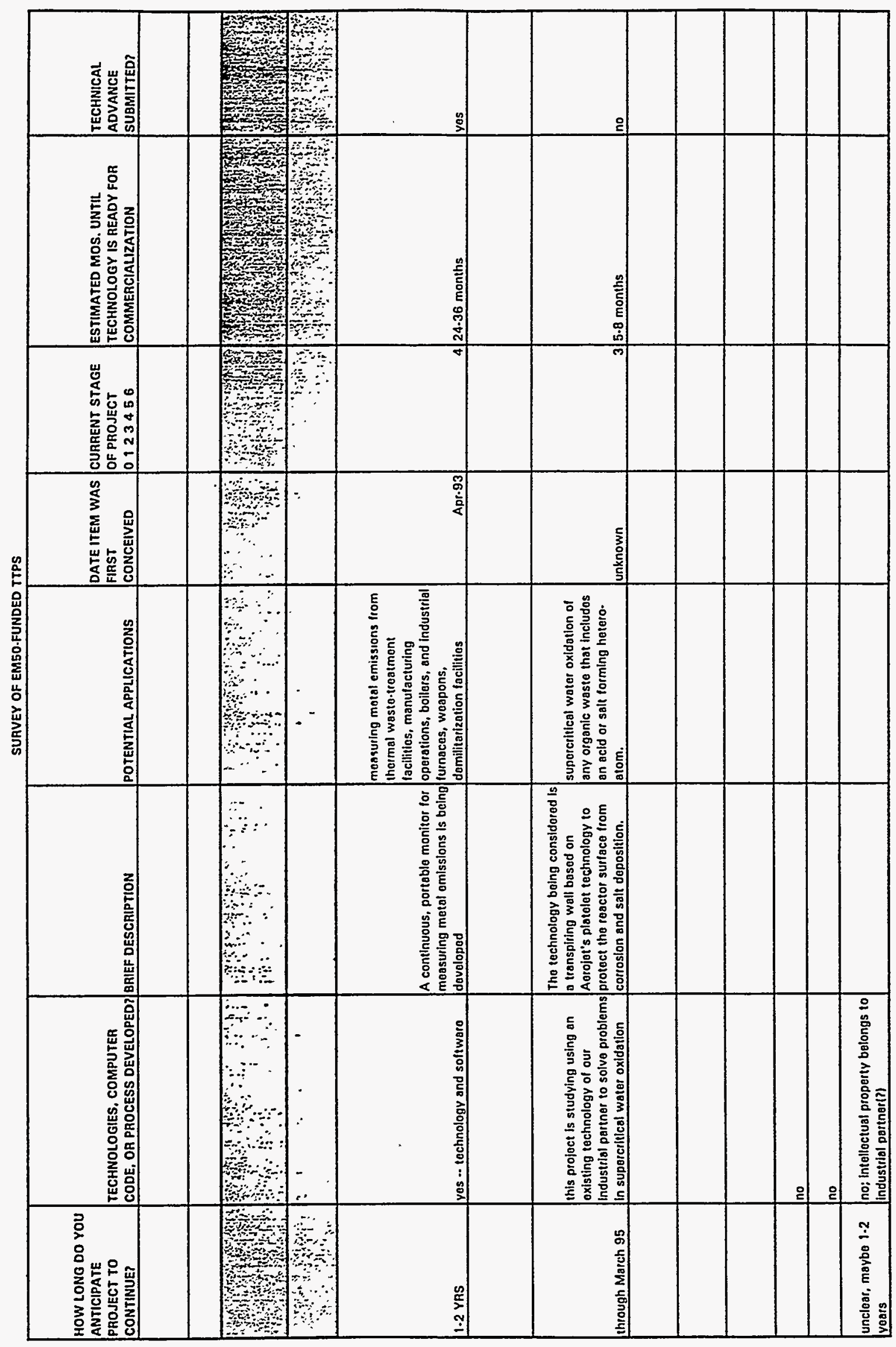

$\stackrel{0}{x}$
5
$\frac{1}{0}$
$\frac{⿱}{3}$
E
$E$ 


\begin{tabular}{|c|c|c|c|c|c|c|c|}
\hline $\begin{array}{l}\text { HOW LONG DO YOU } \\
\text { ANTCIPATE } \\
\text { PROJECT TO } \\
\text { CONTINUE? } \\
\end{array}$ & $\begin{array}{l}\text { TECHNOLOOIES, COMPUTER } \\
\text { CODE, OR PROCESS DEVELOPED? }\end{array}$ & BRIEF DESCAPPTION & POTENTIAL APPLICATIONS & $\begin{array}{l}\text { DATE ITEM WAS } \\
\text { FIFST } \\
\text { CONCEIVED } \\
\end{array}$ & $\begin{array}{l}\text { CURRENT STAGE } \\
\text { OO PROJET } \\
\text { O } 123456\end{array}$ & 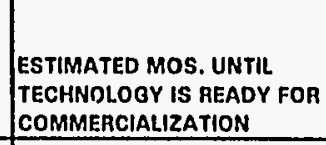 & $\begin{array}{l}\text { TECHNICAL } \\
\text { ADVANE } \\
\text { SUBMMITED? }\end{array}$ \\
\hline 2.3 years & yes & $\begin{array}{l}\text { computer coded for managing } \\
\text { environmontal probtems ond } \\
\text { technologios }\end{array}$ & $\begin{array}{l}\text { computer notwork. } \\
\text { environmentel intormatlon } \\
\text { servico }\end{array}$ & $\begin{array}{l}\text { prototypo - July } \\
1992\end{array}$ & $\begin{array}{l}\text { 6. solfwaro and } \\
\text { data V1.0 to bo } \\
\text { reloassed } 9 / 30 / 94\end{array}$ & & $\begin{array}{l}\text { Yes - patent } \\
\text { dolisclosuro only }\end{array}$ \\
\hline & & & & & & & \\
\hline & & & & & & & \\
\hline & & & & & & & \\
\hline & & & & & & & \\
\hline & & & & & & & \\
\hline & & & & & & & \\
\hline & & & & & & & \\
\hline
\end{tabular}


SURVEY OF EM5O-FUNDED TTPS

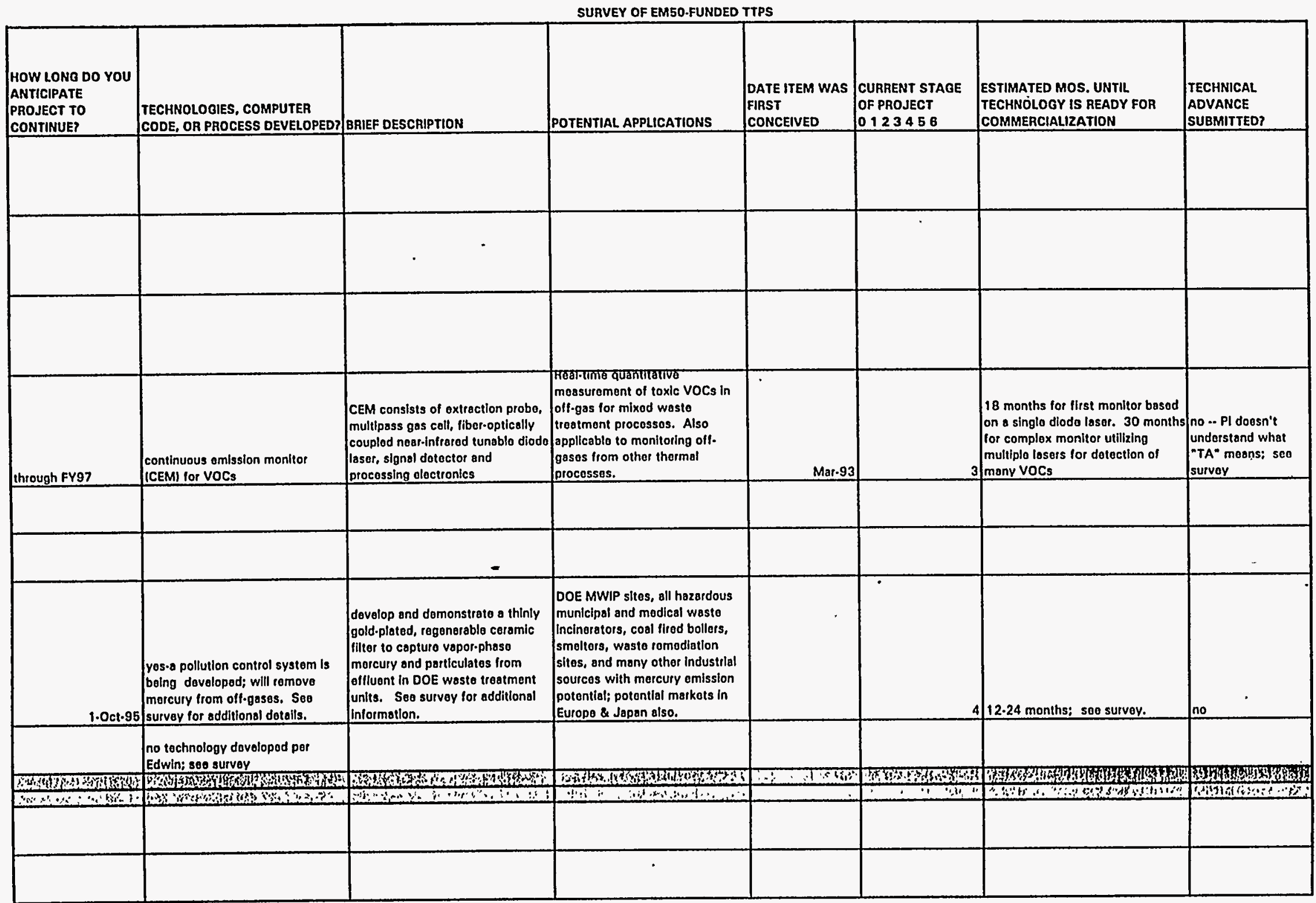


SURVEY OF EMEO.FUNDED TTPS

\begin{tabular}{|c|c|c|c|c|c|c|c|}
\hline $\begin{array}{l}\text { HOW LONG DO YOU } \\
\text { ANTICIPATE } \\
\text { PROJECT TO } \\
\text { CONTINUE? }\end{array}$ & $\begin{array}{l}\text { TECHNOLOQIES, COMPUTER } \\
\text { CODE, OR PROCESS DEVELOPED? }\end{array}$ & BAIEF DESCRIPTION & POTENTIAL APPLICATIONS & \begin{tabular}{|l|} 
DATE ITEM WAS \\
FIRST \\
CONCEIVED \\
\end{tabular} & $\begin{array}{l}\text { CURRENT STAGE } \\
\text { OF PROJECT } \\
0123466 \\
\end{array}$ & $\begin{array}{l}\text { ESTIMATED MOS. UNTIL } \\
\text { TECHNOLOOY IS READY FOR } \\
\text { COMMERCIALIZATION }\end{array}$ & $\begin{array}{l}\text { TECHNICAL } \\
\text { ADVANCE } \\
\text { SUBMITTED? }\end{array}$ \\
\hline & yes & $\begin{array}{l}\text { lasor ablativo cleaning and } \\
\text { soldering; controllod atmosphere } \\
\text { soldering; ultrosonic soldering: } \\
\text { protectlvo base coatings }\end{array}$ & microolactronles assambly & FY89/90 & $T / 3$ & project terminoted, not applicable & yes \\
\hline & yes & lood lloo solder pasto & pernind witing boasd industry & May.93 & $T / 6$ & 0 & vos \\
\hline & no & - & & & & & \\
\hline 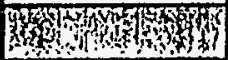 & 7. & 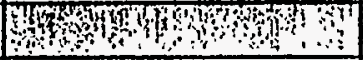 & a & $\because \because 4$ & 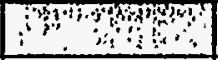 & : & W \\
\hline 2 yoars & yes & $\begin{array}{l}\text { Dovolopod above ground and down } \\
\text { hole monitoring systoms for } \\
\text { volatite organics }\end{array}$ & $\begin{array}{l}\text { Environmental monitoring, field } \\
\text { scrooning, industrial process, } \\
\text { waste and oxhaust monitoring. } \\
\text { personnel monitoring. }\end{array}$ & 1989 & & $\begin{array}{l}\text { currently workding with two } \\
\text { industrial partners. Expected to be } \\
\text { commercially available in } 2 \text { years. }\end{array}$ & ves \\
\hline end of FY 94 & yes & $\begin{array}{l}\text { Wo aro using liquid and } \\
\text { supercritical carbon dioxide to } \\
\text { soparate the hazardous solvents } \\
\text { and oils and greases from the } \\
\text { nonhazardous solid debris. It } \\
\text { works very well. } \\
\text { Real-time monitoring system for } \\
\text { cleaning processes } \\
\end{array}$ & $\begin{array}{l}\text { Recycling malntenanco rags, } \\
\text { coverall, otc. Soparating the } \\
\text { hazardous component so it can } \\
\text { bo disposod of properly } \\
\text { (oxponsively) and tho debris can } \\
\text { ba put in a sanitary landfill. } \\
\text { Roal-time monitoring of cleaning } \\
\text { processes (soo Fryo survey for } \\
\text { moral }\end{array}$ & 1992 & & $\begin{array}{l}\text { This project is folnt with } \\
\text { AlliadSignal.Kansas City and our } \\
\text { irst application is to dosign a } \\
\text { systom for their Wasto } \\
\text { Management Dapartment. Aftor } \\
\text { that, who knows. } \\
12 \text { months } \\
\end{array}$ & $\begin{array}{l}\text { ' } \\
\text { no } \\
\text { background patont } \\
\text { already held } \\
\end{array}$ \\
\hline d of FY94 & $\begin{array}{l}\text { not for selismic under this IIP. } \\
\text { we're working on new seismlc } \\
\text { source dovolopmont under new } \\
\text { TTP }\end{array}$ & & & & & & \\
\hline
\end{tabular}




\begin{tabular}{|c|c|c|c|c|c|c|c|}
\hline $\begin{array}{l}\text { HOW LONG DO YOU } \\
\text { ANTICIPATE } \\
\text { PROJECT TO } \\
\text { CONTINUE? } \\
\end{array}$ & $\begin{array}{l}\text { TECHNOLOQIES, COMPUTER } \\
\text { CODE, OR PROCESS DEVELOPED? }\end{array}$ & BPIEF DESCRIPTION & POTENTIAL APPLICATIONS & $\begin{array}{l}\text { DATE ITEM WAS } \\
\text { FIRST } \\
\text { CONCEIVED }\end{array}$ & $\begin{array}{l}\text { CURRENT STAGE } \\
\text { OF PROJECT } \\
0123456\end{array}$ & $\begin{array}{l}\text { ESTIMATED MOS. UNTIL } \\
\text { TECHNOLOGY IS READY FOR } \\
\text { COMMERGIALIZATION } \\
\end{array}$ & $\begin{array}{l}\text { TECHNICAL } \\
\text { ADVANCE } \\
\text { SUBMITTED? }\end{array}$ \\
\hline & yes - processes & $\begin{array}{l}\text { 1. alternative to coppor cyanido } \\
\text { plating 2. plating wasto tank } \\
\text { sensor }\end{array}$ & $\begin{array}{l}\text { 1. printed circuit board } \\
\text { rabrication and ollectroforming } \\
\text { applications involving "coppor } \\
\text { stritea" 2. ang electroplating } \\
\text { operation }\end{array}$ & 9/11/92 & T/5; seo survay & 3.6 months & no \\
\hline & $\begin{array}{l}\text { Yes - the gonoral concopt of Laser } \\
\text { Ablativiv Fiuxless Soldering was } \\
\text { concelvod directly from AL201304 } \\
\text { offlots. }\end{array}$ & $\begin{array}{l}\text { Laser Ablativo Fluxloss Soldering } \\
\text { uses laser ablation under an inert } \\
\text { gos stmosphore to form solder } \\
\text { loints without the use of sny type } \\
\text { of chemical flux. } \\
\end{array}$ & 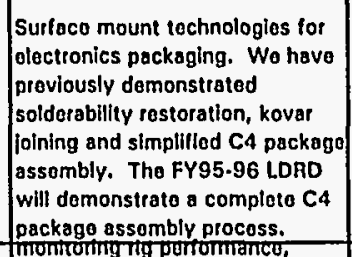 & undocumented & stage 3.6 & $\begin{array}{l}\text { somo aspocts can bo utllized now. } \\
\text { Our current research on C4 } \\
\text { package essombly should bo ready } \\
\text { in } 12.24 \text { months }\end{array}$ & yes \\
\hline $\begin{array}{l}\text { thru FY95, probably } \\
\text { FY98 }\end{array}$ & yes & 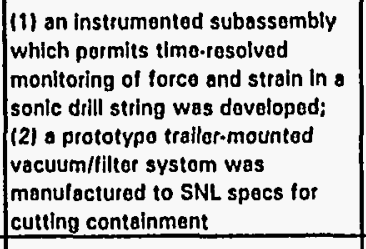 & 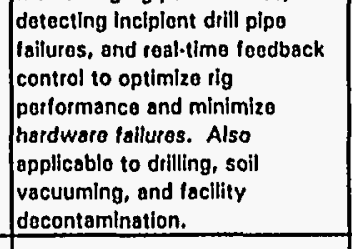 & & $\begin{array}{l}\text { sonic subassombly. } \\
4 \\
\text { vacuum/filtor } \\
\text { systom } 66\end{array}$ & $\begin{array}{l}12 \text { months (instrumontod sonic } \\
\text { subassembly) }\end{array}$ & no \\
\hline Ond of FY 94 & 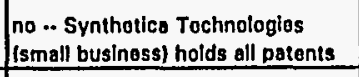 & & & & & & \\
\hline & & & & & & & \\
\hline & & & & & & & \\
\hline & & & & & & & \\
\hline & & & & & & & \\
\hline
\end{tabular}




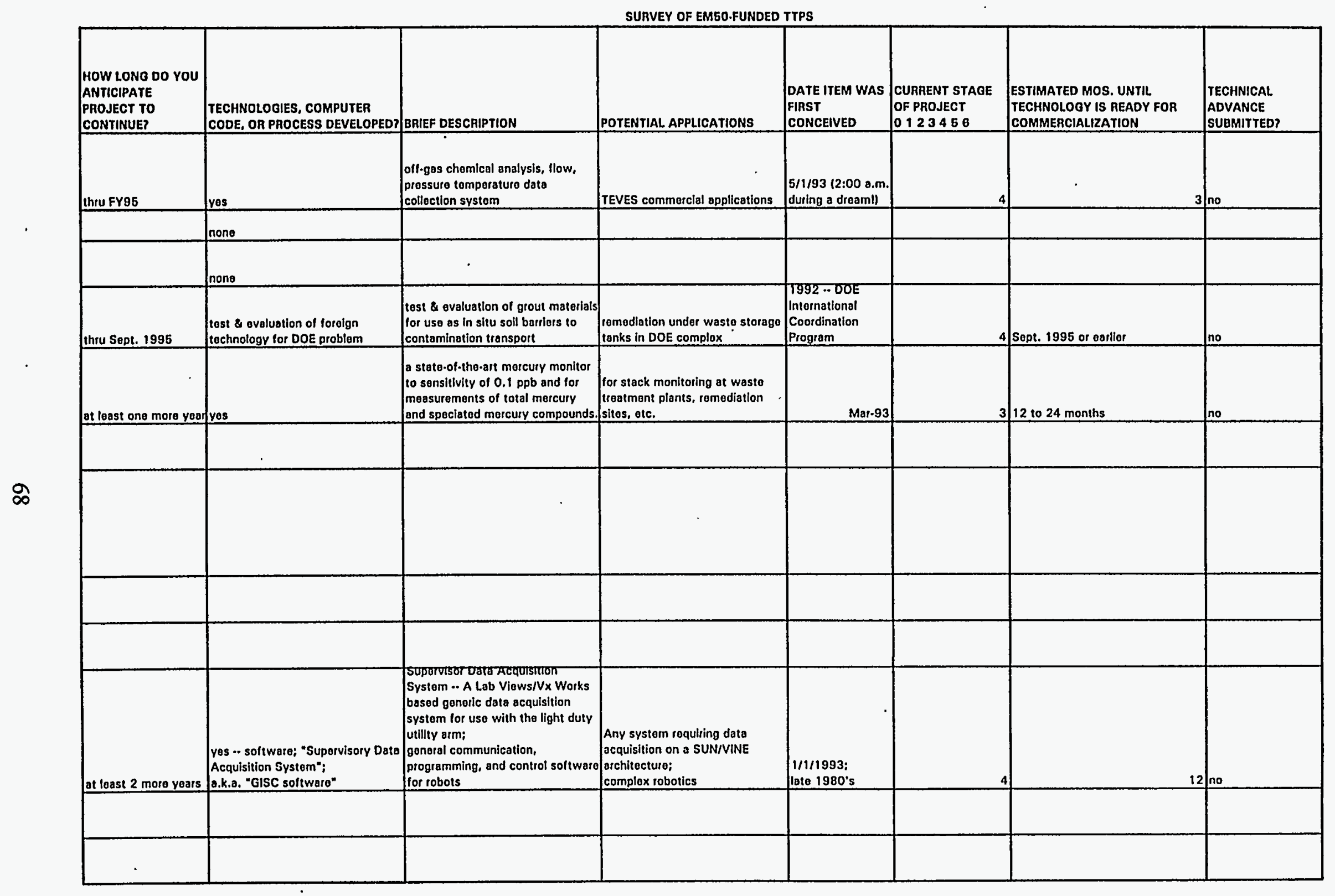




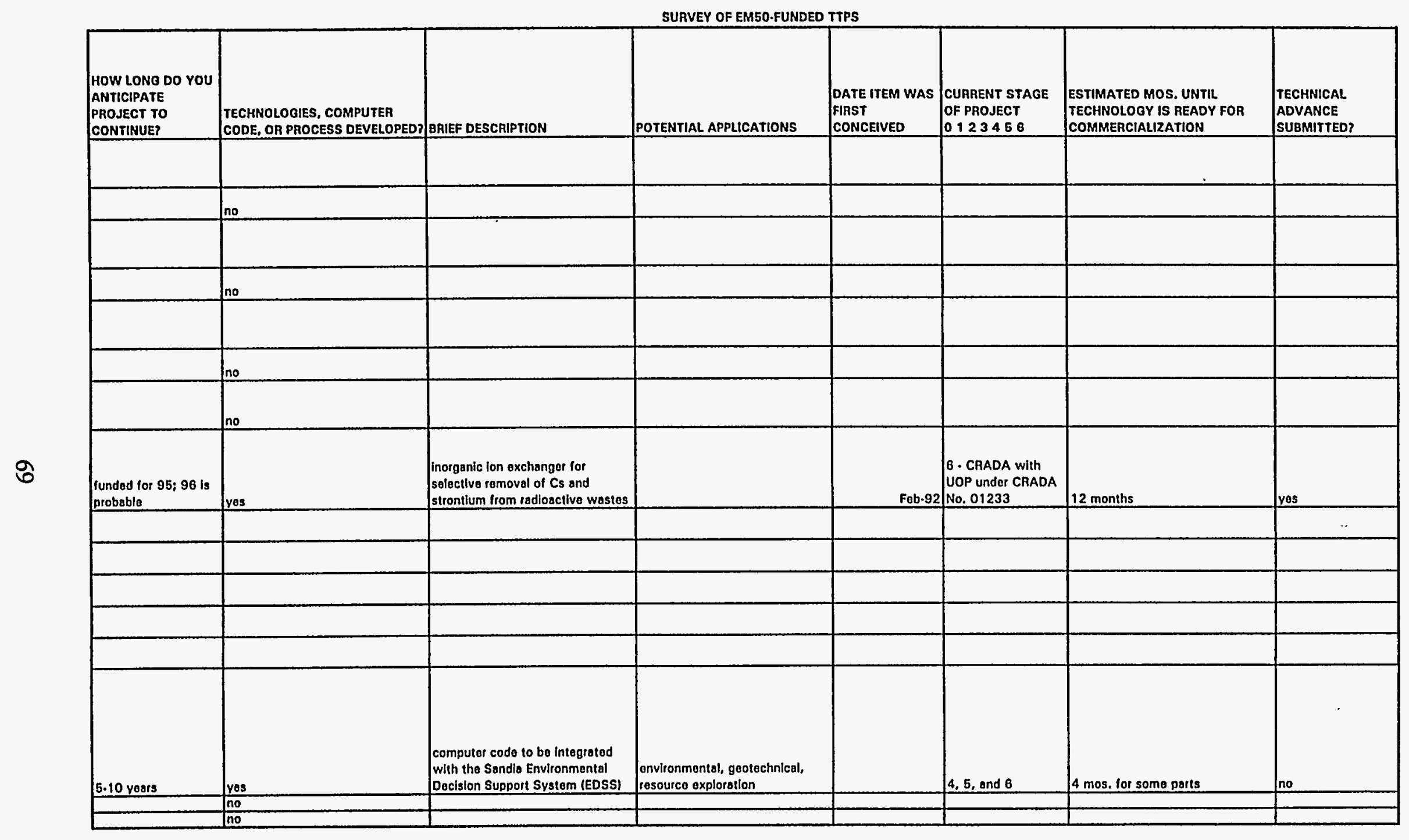




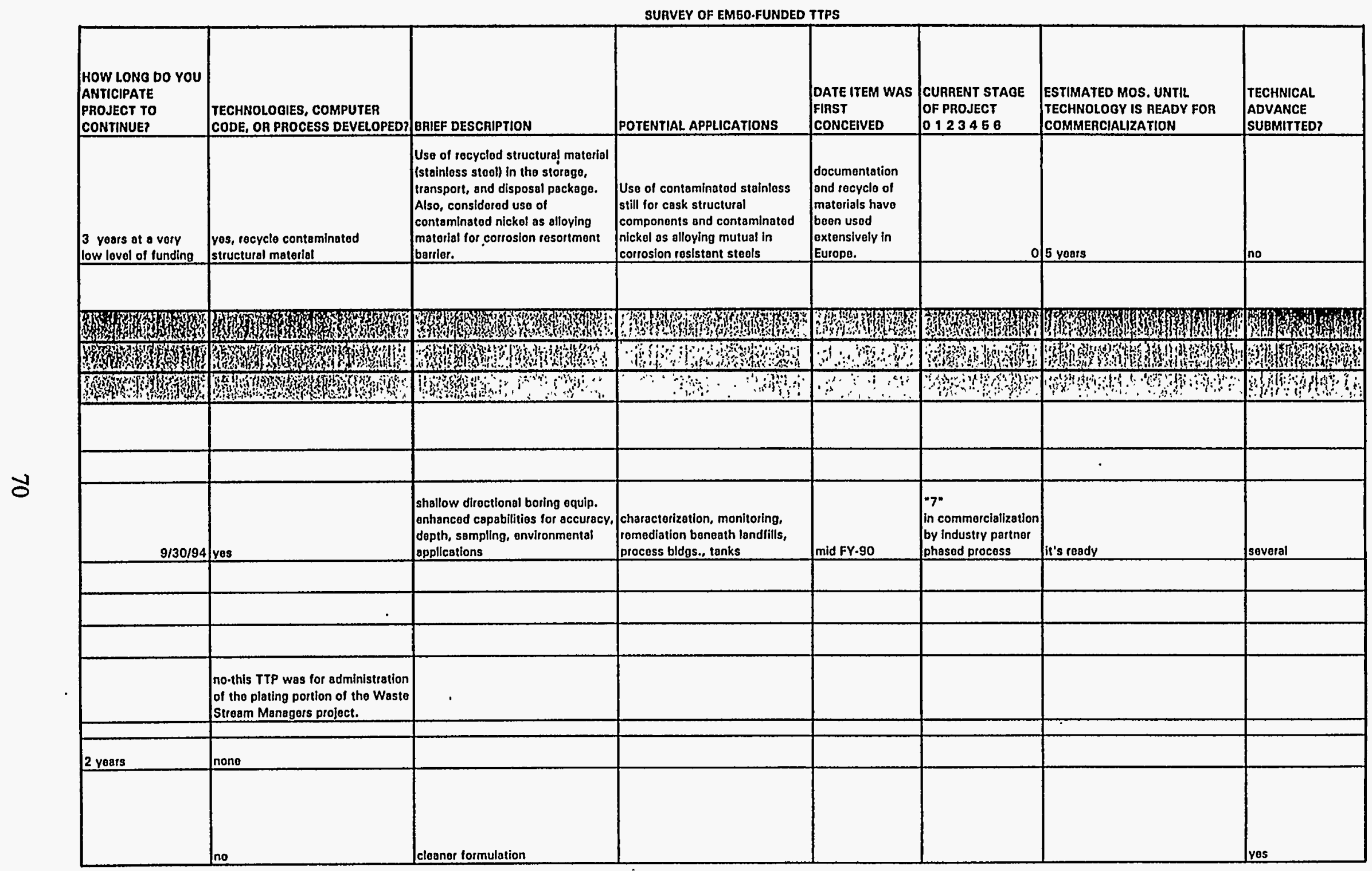




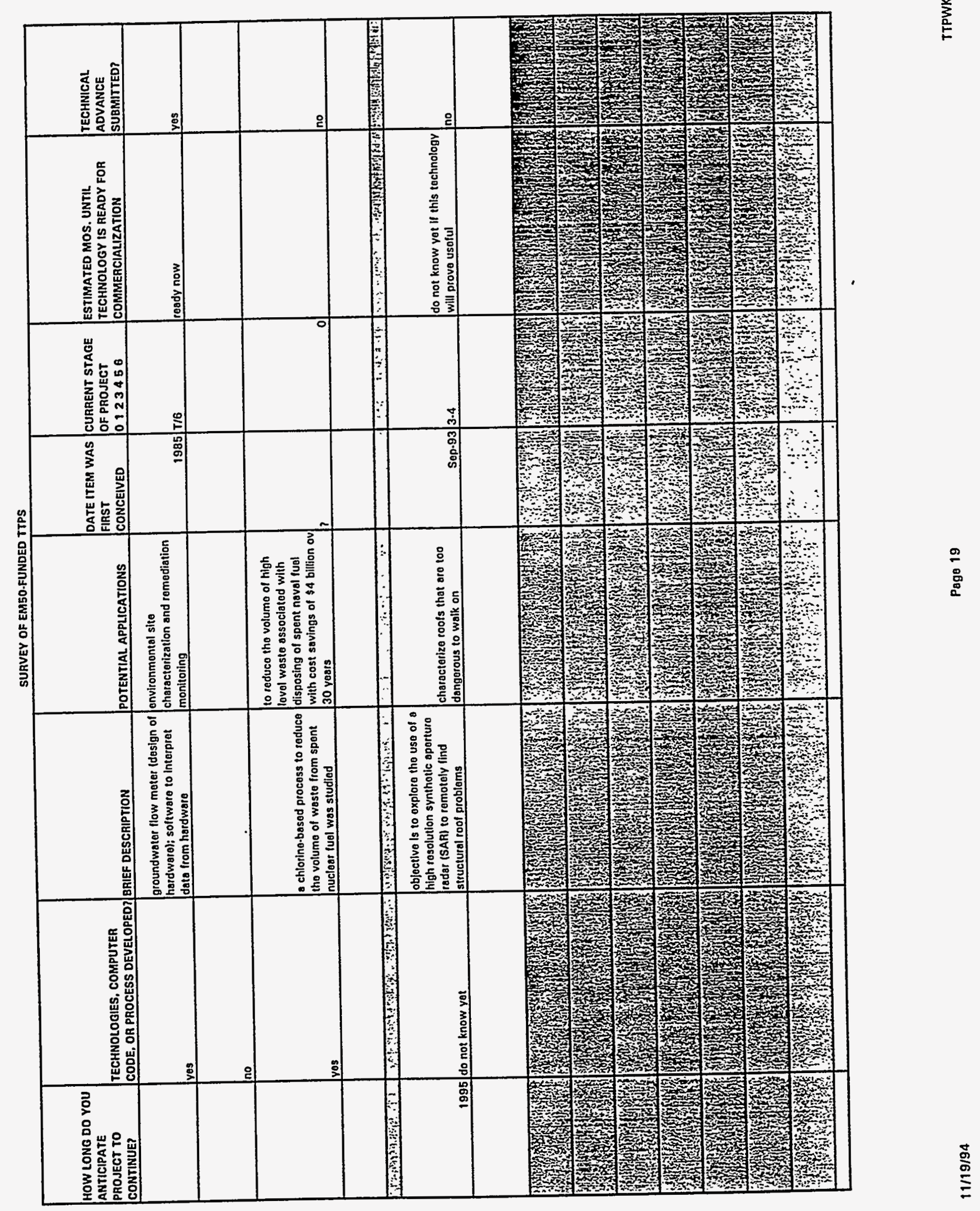


SURVEY OF EMEO.FUNDED TIPS

\begin{tabular}{|c|c|c|c|c|c|c|c|}
\hline $\begin{array}{l}\text { HOW LONO DO YOU } \\
\text { ANTICIPATE } \\
\text { PROJECT TO } \\
\text { CONTINUE? }\end{array}$ & $\begin{array}{l}\text { TECHNOLOQIES, COMPUTER } \\
\text { CODE, OR PROCESS DEVELOPED? }\end{array}$ & BAIEF DESCRIPTION & POTENTIAL APPLICATIONS & $\begin{array}{l}\text { DATE ITEM WAS } \\
\text { FIAST } \\
\text { CONCEIVED }\end{array}$ & $\begin{array}{l}\text { CURRENT STAOE } \\
\text { OF PROJECT } \\
0123466\end{array}$ & $\begin{array}{l}\text { ESTIMATED MOS. UNTIL } \\
\text { TECHNOLOQY IS READY FOR } \\
\text { COMMERCIALIZATION }\end{array}$ & $\begin{array}{l}\text { TECHNICAL. } \\
\text { ADVANCE } \\
\text { SUBMITTED? }\end{array}$ \\
\hline & & & & & & & \\
\hline & & & & & & & \\
\hline & & & & & . & & \\
\hline & & & & & & & \\
\hline & & & & & & & \\
\hline & & & & & & & \\
\hline & & & & & & & \\
\hline & & & & & & & \\
\hline & & & i & & & & \\
\hline
\end{tabular}




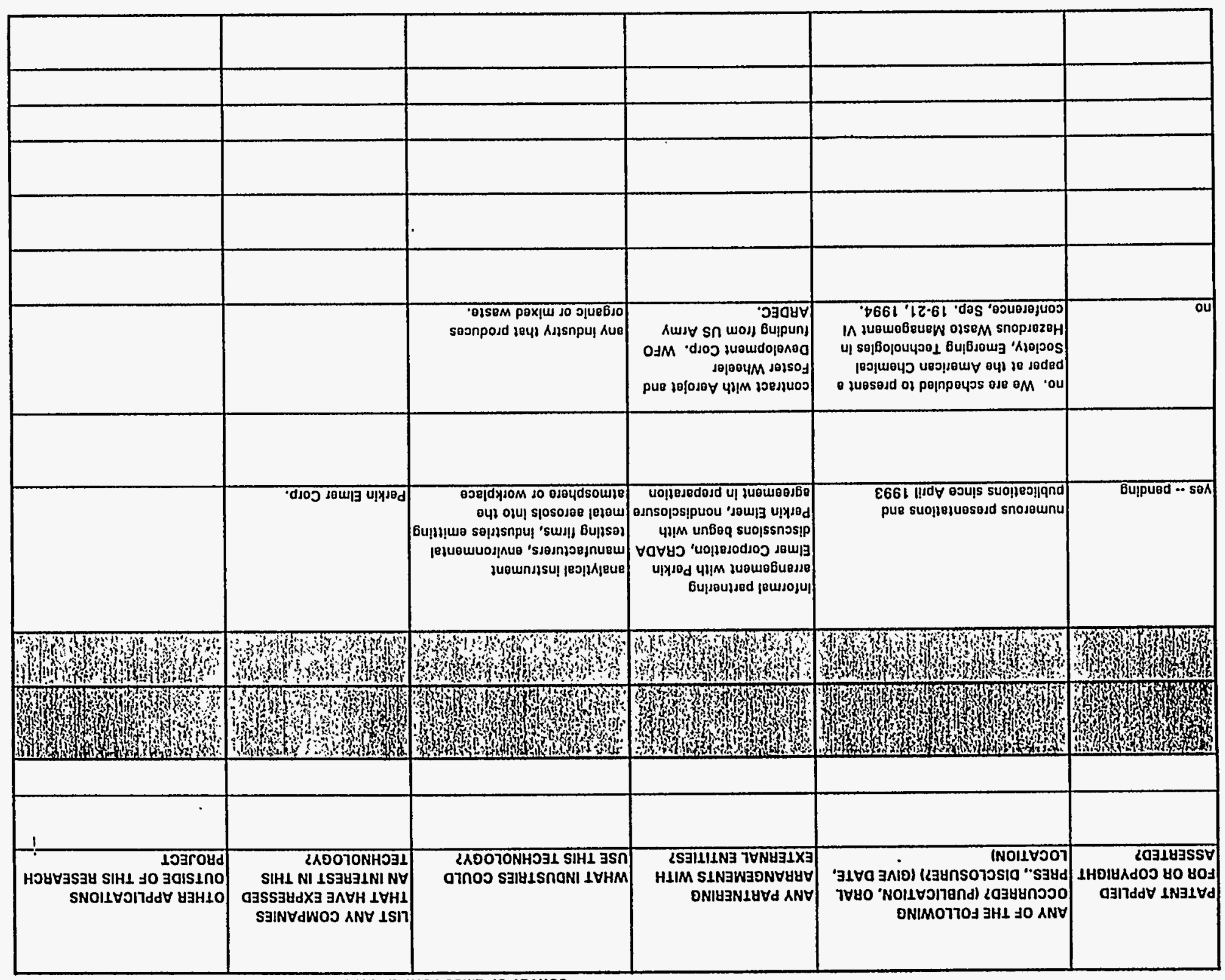




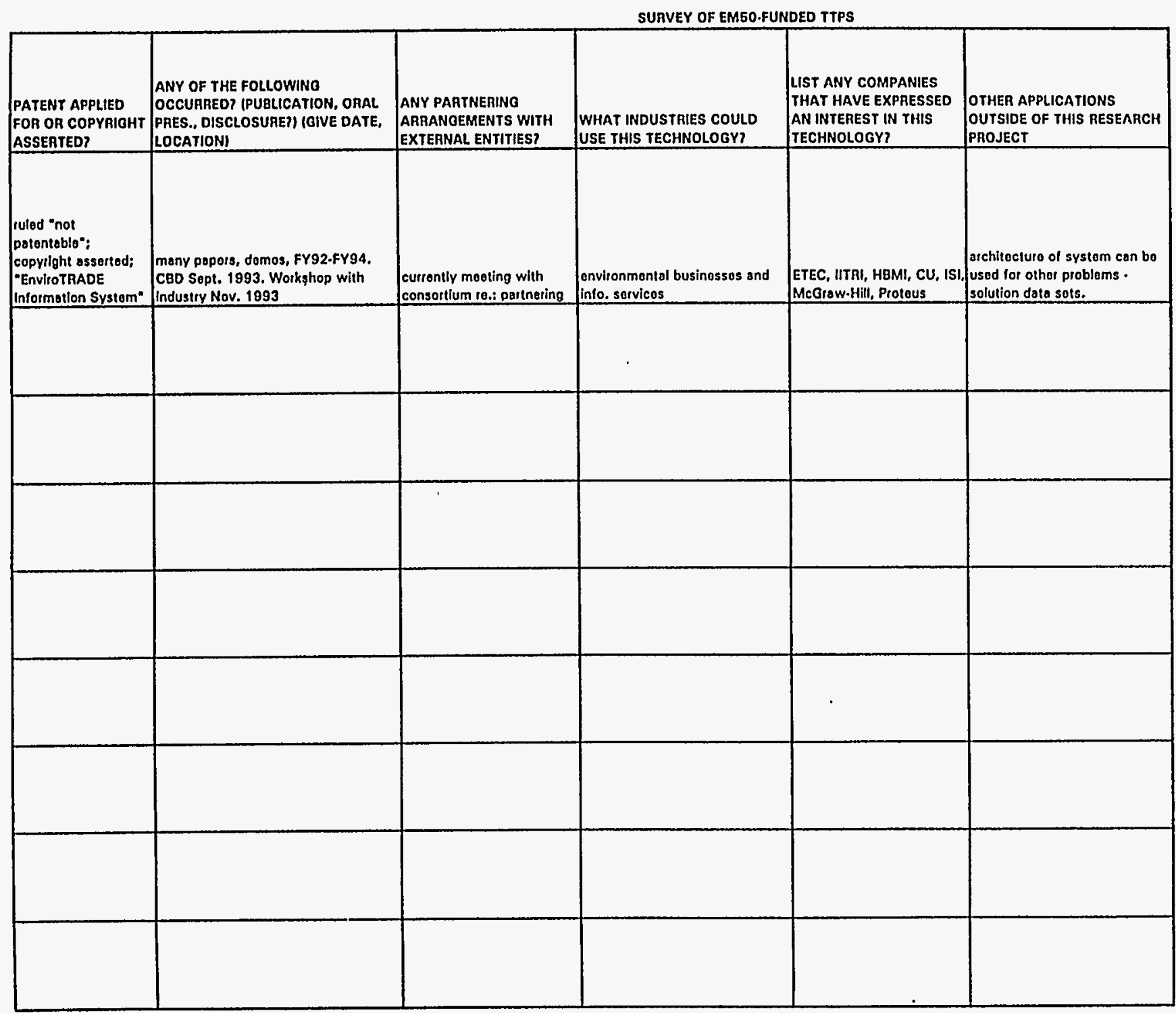




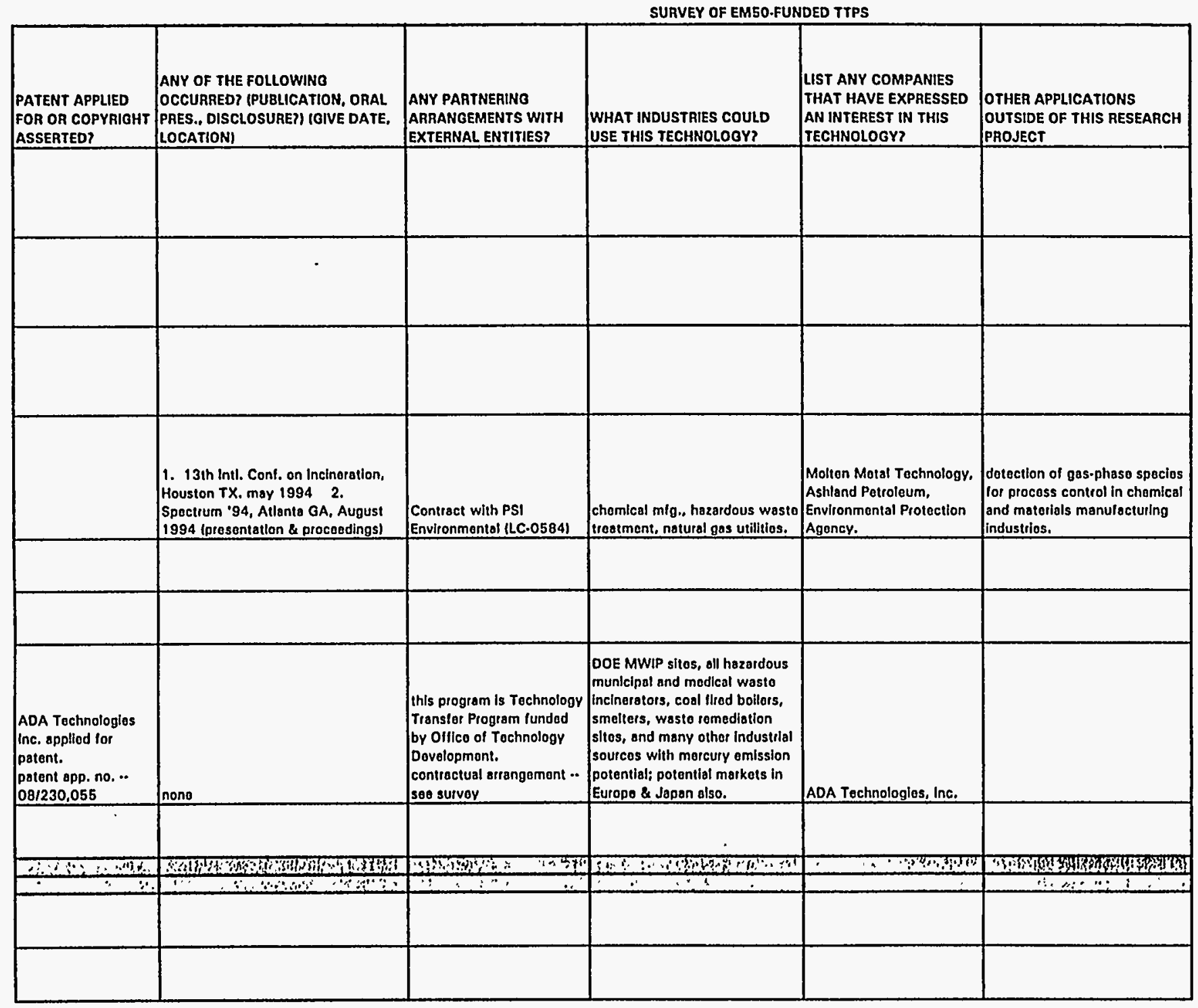




\begin{tabular}{|c|c|c|c|c|c|}
\hline $\begin{array}{l}\text { PATENT APPLLED } \\
\text { FOR OR COPYRIGHT } \\
\text { ASSERTEDY }\end{array}$ & $\begin{array}{l}\text { ONY OF THE FOLLOWINO } \\
\text { OCCURRED (PULLLCATION, ORAL } \\
\text { PRES., OISGLOSURE) (GIVE DATE, } \\
\text { LOCATION) } \\
\end{array}$ & $\begin{array}{l}\text { ANY PARTNERINO } \\
\text { ARRANGEMENTS WITH } \\
\text { EXTERAAL ENTITIES? }\end{array}$ & $\begin{array}{l}\text { WHAT INDUSTRIES COULD } \\
\text { USE THIS TECHNOLOQYY }\end{array}$ & $\begin{array}{l}\text { LIST ANY COMPANIES } \\
\text { THAT HAVE EXPRESSED } \\
\text { AN INTEREST IN THIS } \\
\text { TECHNOLOQYY } \\
\end{array}$ & $\begin{array}{l}\text { OTHER APPLICATIONS } \\
\text { OUTSIDE OF THIS RESEARCH } \\
\text { PROJECT }\end{array}$ \\
\hline no & 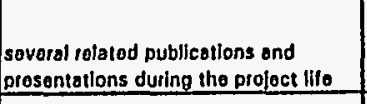 & vos- univorsity contracts & 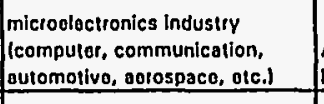 & $\begin{array}{l}\text { AT\&T, TI, IEM, Motorola, } \\
\text { Ford, olc. }\end{array}$ & $\begin{array}{l}\text { any soldering applications that } \\
\text { roquiro ECM procossing }\end{array}$ \\
\hline yos. & $\begin{array}{l}\text { The Matillutigical Socitity Spring Mto. } \\
\text { - San Frenclsco, CA } \\
\text { i. Anderson } \\
\text { c. Millor }\end{array}$ & DOE Ames LOB - Ames, IA & olectionics & $\begin{array}{l}\text { Alpha Motals and Johnson } \\
\text { Mog. both make and sell } \\
\text { solderes }\end{array}$ & \\
\hline 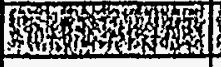 & 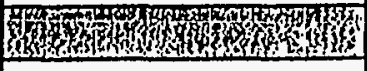 & 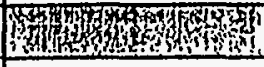 & PBn & 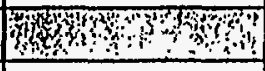 & AIDBh \\
\hline 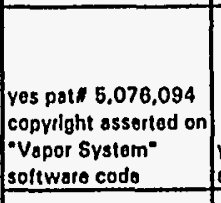 & $\begin{array}{l}\text { ros ... 1990+ .. many times on all } \\
\text { escounts }\end{array}$ & $\begin{array}{l}\text { Woiked undor MOA. } \\
\text { Currontly settifg up o } \\
\text { CRADA ond an MOA. }\end{array}$ & 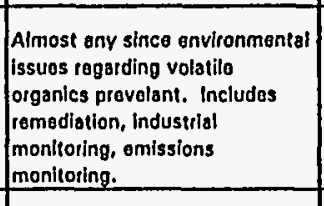 & 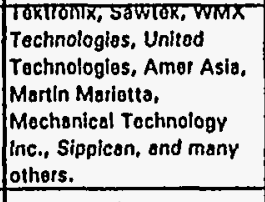 & 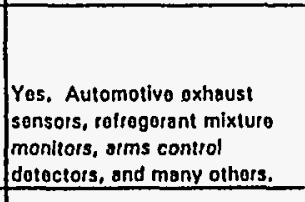 \\
\hline & 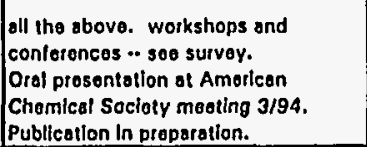 & no & 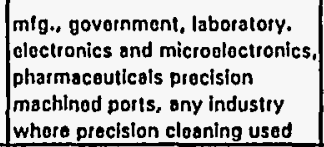 & $\begin{array}{l}\text { somo companios havo, but } \\
\text { it's nobulous. } \\
\text { yes i- Sterting Winthrop } \\
\text { pharmaceuticals but koy } \\
\text { contact left company }\end{array}$ & 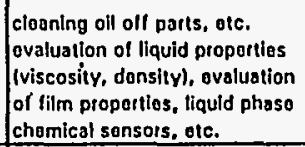 \\
\hline & & & & & \\
\hline & & & & & \\
\hline
\end{tabular}


SURVEY OF EM5O-FUNDED TTPS

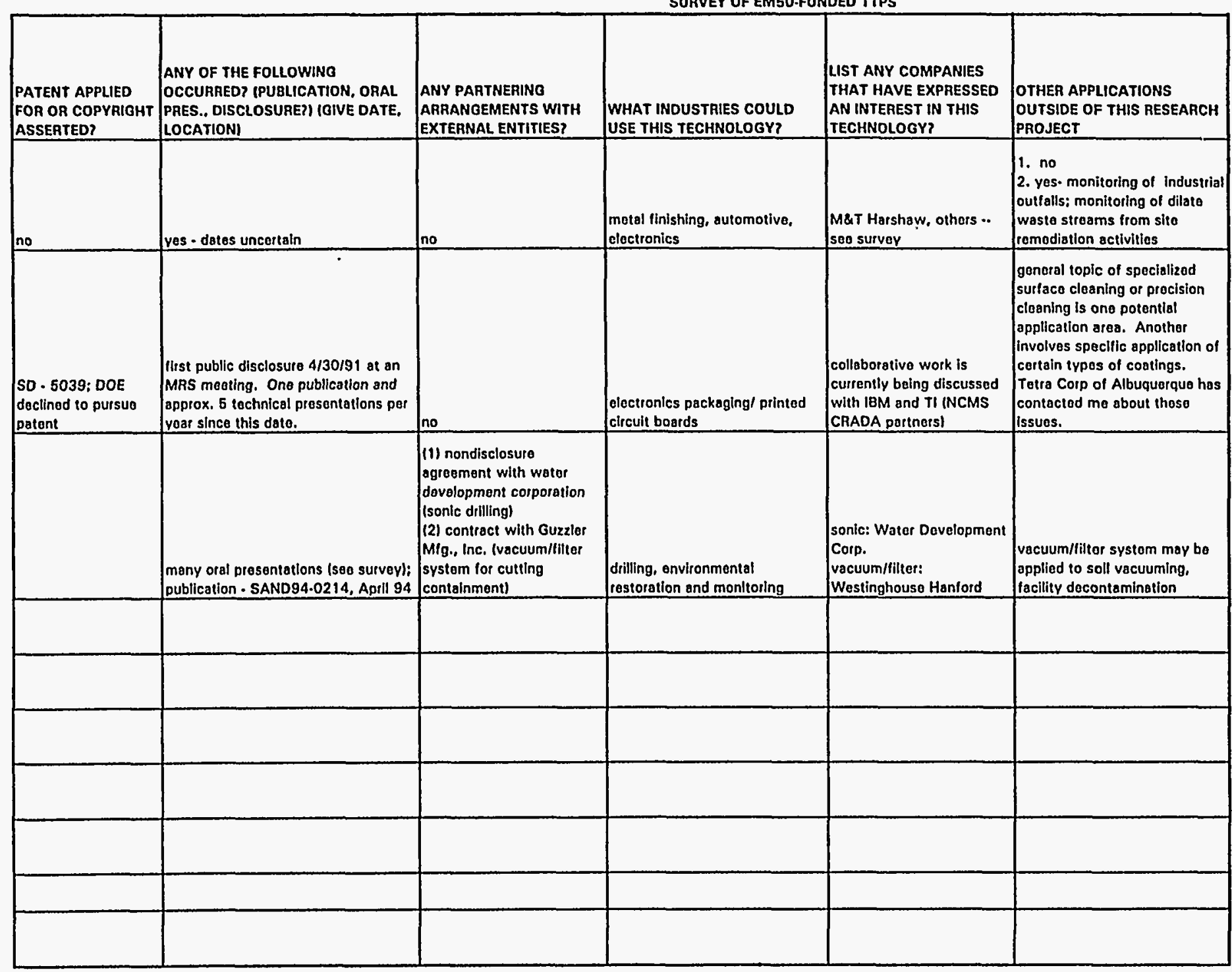




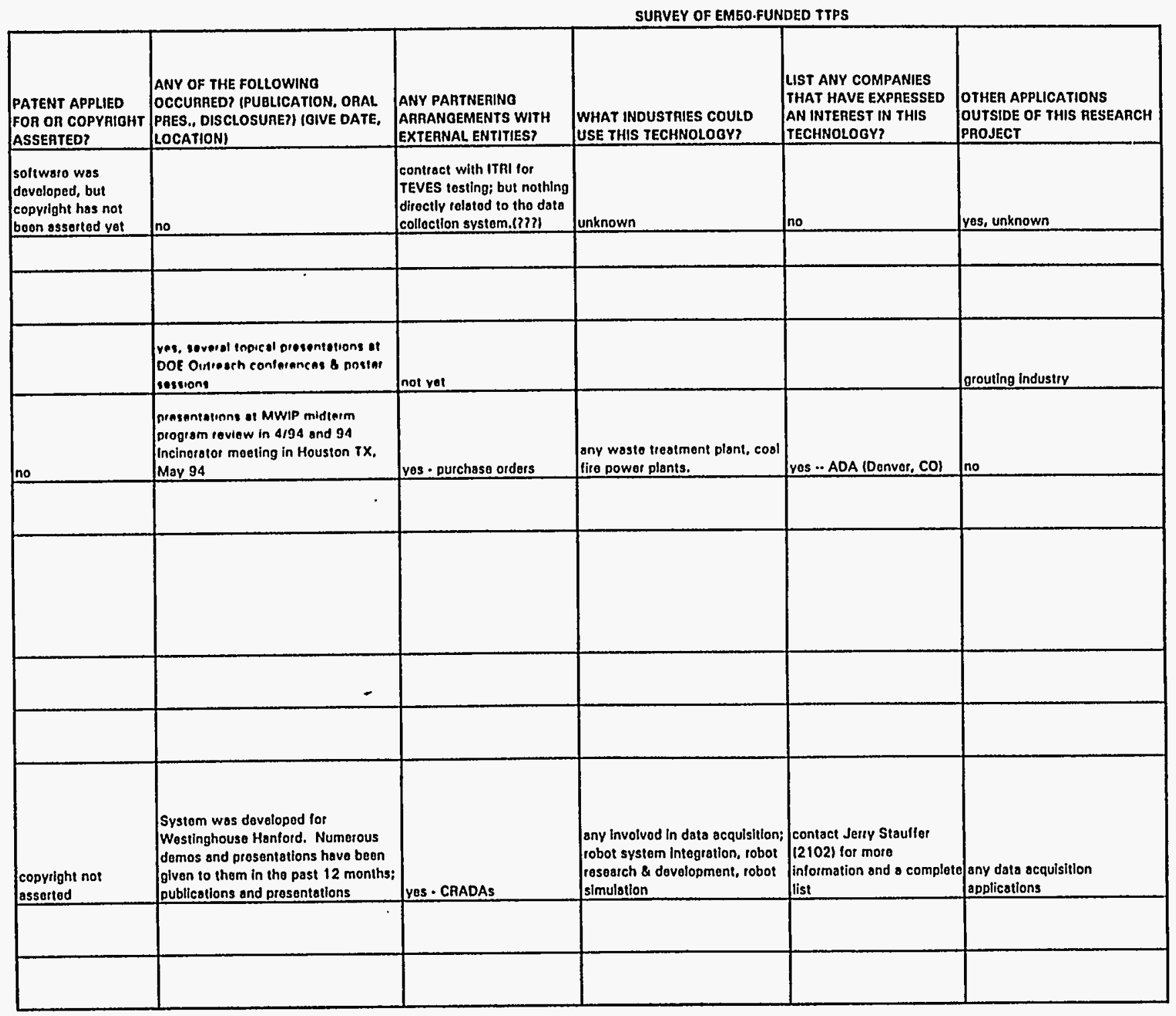


SURVEY OF EMSO.FUNDED TTPS

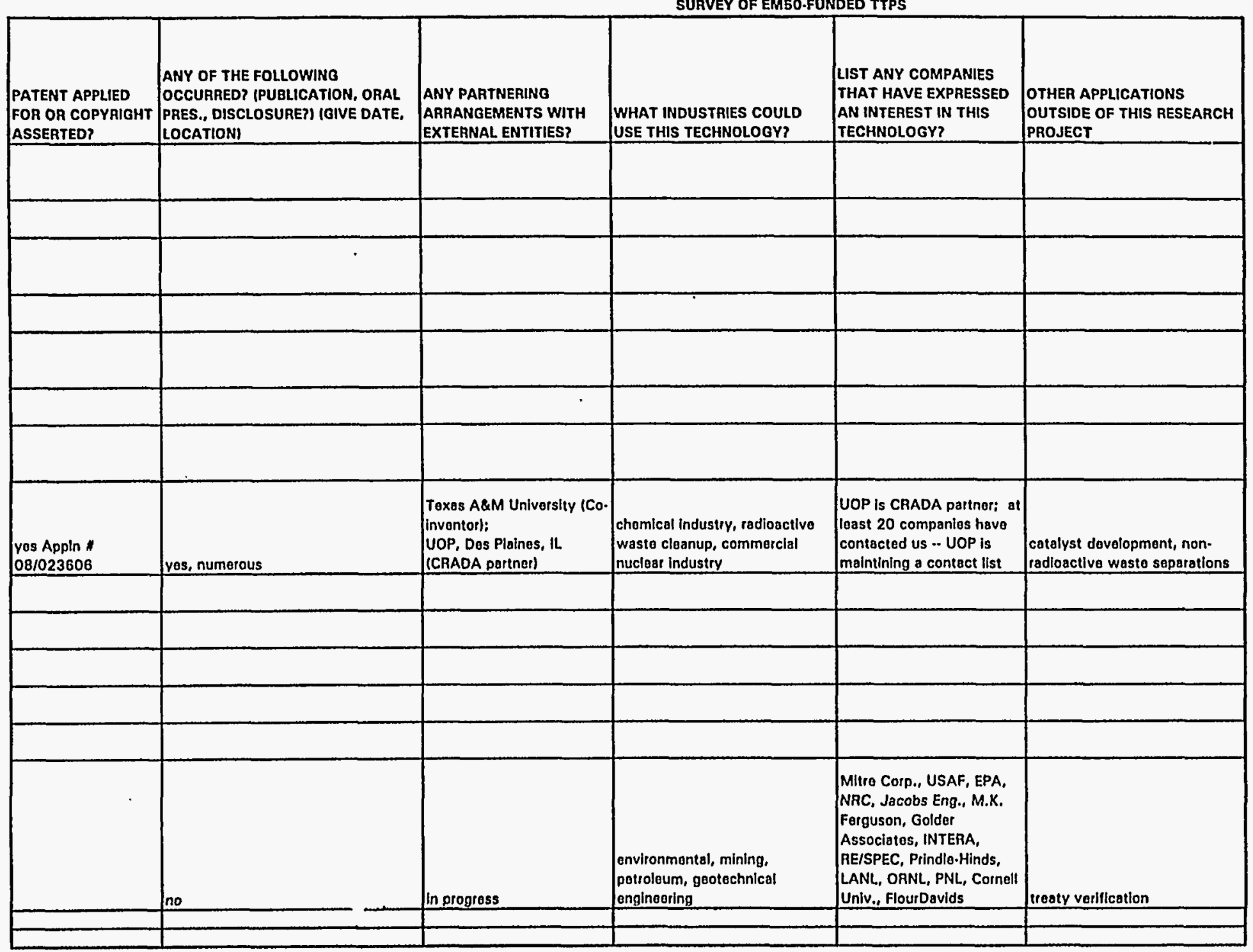




\begin{tabular}{|c|c|c|c|c|c|}
\hline & & & SURVEY OF EMEO.FUN & JDED TTPS & \\
\hline $\begin{array}{l}\text { PATENT APPLIED } \\
\text { FOR OR COPYRIOHT } \\
\text { ASSERTED? }\end{array}$ & $\begin{array}{l}\text { ANY OF THE FOLLOWINO } \\
\text { OCCURRED? FUBUIACTION, ORAL } \\
\text { PRES,, DISCLOSUREA (GIVE DATE. } \\
\text { LOCATION) }\end{array}$ & $\begin{array}{l}\text { ANY PARTNERING } \\
\text { ARRANGEMENTS WITH } \\
\text { EXTERNAL ENTITIISS? }\end{array}$ & $\begin{array}{l}\text { WHAT INDUSTRIES COULD } \\
\text { USE THIS TECHNOLOOY? } \\
\end{array}$ & $\begin{array}{l}\text { LIST ANY COMPANES } \\
\text { THAT HAVE EXPEESSED } \\
\text { AN INTEREST IN THIS } \\
\text { TECHNOLOGY? } \\
\end{array}$ & $\begin{array}{l}\text { OTHER APPLICATIONS } \\
\text { OUTSIDE OF THIS RESEARCH } \\
\text { PROJECT }\end{array}$ \\
\hline & Oral presentations, June 1994 & $\begin{array}{l}\text { No, consldered for futuro } \\
\text { proposal }\end{array}$ & loundiy & & $\begin{array}{l}\text { other applications were not } \\
\text { considered }\end{array}$ \\
\hline 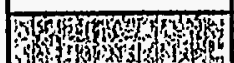 & N3y & W & BH, & Whow ow & W \\
\hline otyigh & 倣 & 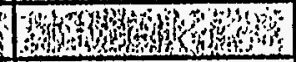 & Hownown & How why & 15 \\
\hline 4fon & 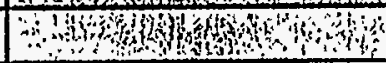 & mons & and & 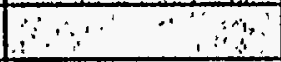 & $\therefore \quad 0019$ \\
\hline & & & & & \\
\hline $\begin{array}{l}\text { disclosuros, walvors, } \\
\text { patents, and liconsing } \\
\text { ongoing }\end{array}$ & 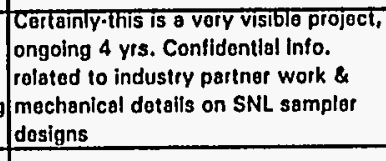 & $\begin{array}{l}\text { pro.CRADA, no.cost, } \\
\text { partnershhlp witc Charles } \\
\text { Machin W Works (Ditch } \\
\text { witch) .. Porry, OK. }\end{array}$ & $\begin{array}{l}\text { envifonmental, undorground } \\
\text { uutilitits, soil mechanics, civil } \\
\text { engineasing, small fiver crossing. }\end{array}$ & seo inlo attached to survey & \\
\hline & & & & & \\
\hline & & & & & \\
\hline & & & & & \\
\hline & & & & & \\
\hline noo & & $\begin{array}{l}\text { thils program has helped } \\
\text { small companies to replace } \\
\text { ozone.dopleting chemicals } \\
\text { Ior cleaning. IRMS, } \\
\text { Reynolds Industries, inc.. } \\
\text { TEAMI }\end{array}$ & industries requiring claaning & & \\
\hline
\end{tabular}




\begin{tabular}{|c|c|c|c|c|c|}
\hline $\begin{array}{l}\text { PATENT APPLLED } \\
\text { FOA OR COPYRIGHT } \\
\text { ASSERTED? }\end{array}$ & $\begin{array}{l}\text { ANY OF THE FOLLOWINO } \\
\text { OCCURRED? (PUBLICATION, ORAL } \\
\text { PRES.. DISCLOSURE?I IOIVE DATE, } \\
\text { LOCATION) } \\
\end{array}$ & $\begin{array}{l}\text { ANY PARTNERING } \\
\text { ARRANGEMENTS WITH } \\
\text { EXTERNAL ENTITIES? }\end{array}$ & $\begin{array}{l}\text { WHAT INDUSTAIES COULD } \\
\text { USE THIS TECHNOLOOY? }\end{array}$ & $\begin{array}{l}\text { LIST ANY COMPANIES } \\
\text { THAT HAVE EXPRESSED } \\
\text { AN INTEREST IN THIS } \\
\text { TECHNOLOOY? } \\
\end{array}$ & $\begin{array}{l}\text { OTHER APPLICATIONS } \\
\text { OUTSIDE OF THIS RESEARCH } \\
\text { PROJECT }\end{array}$ \\
\hline \multirow[t]{2}{*}{$\begin{array}{l}\text { no patent: copyight } \\
\text { asserted on soltwato } \\
\text { tiflod "Flow" }\end{array}$} & yos, many & yes, Industry - llcense & environmental consulting & SIE, InC. & $\begin{array}{l}\text { civil engineering, oceanographic } \\
\text { research }\end{array}$ \\
\hline & $\begin{array}{l}\text { linal report - The Reduced Nuclear } \\
\text { Wosto (RENUWW) dry halido procoss } \\
\text { ror nuclear fuol reprocossing Aug. 14. } \\
\text { 1991; prosentatlon at Amor. Chem. } \\
\text { Soc. mtg. - 4/93. } \\
\end{array}$ & $\begin{array}{l}\text { res - Westinghouso } \\
\text { Scionce \& Technology } \\
\text { Contor (Pittsburght and } \\
\text { Wostinghouso Idaho } \\
\text { Nucloar Company } \\
\text { iWINCOI. }\end{array}$ & nuclear power industry & nono & nono \\
\hline 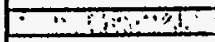 & 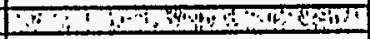 & 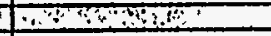 & $10 \cdot 9,18$ & $\because$ & 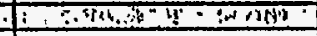 \\
\hline & no & $\begin{array}{l}\text { projoct was to bo dono } \\
\text { cooperativoly with PNL }\end{array}$ & othor DOE tacllities & nono & unknown \\
\hline ofor & W & them & W & 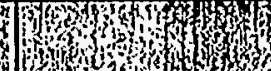 & 3. \\
\hline 的, & ons & (1) & 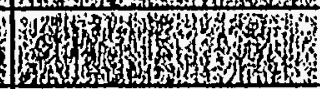 & Whing & 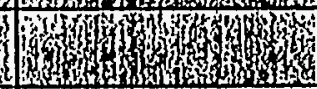 \\
\hline mo & 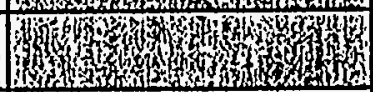 & 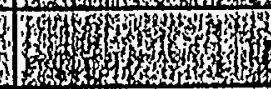 & Hot & 俩 & 1. \\
\hline syom & 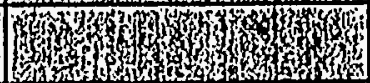 & 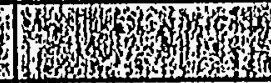 & 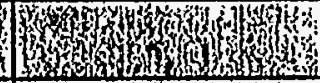 & A Hind & 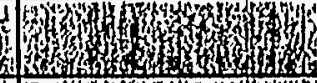 \\
\hline 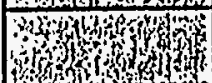 & 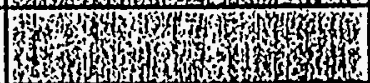 & (6) & 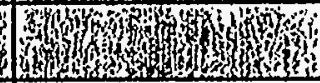 & hon & 10 \\
\hline 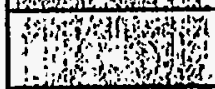 & of & 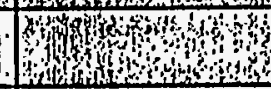 & fold wh & 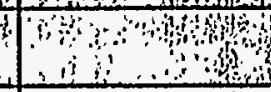 & in \\
\hline sofyothy & of & 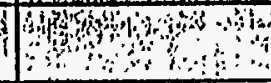 & 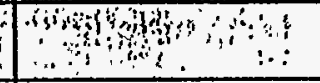 & 1 & $\begin{array}{l}a \\
\therefore\end{array}$ \\
\hline & & & & & \\
\hline
\end{tabular}


SURVEY OF EMEO-FUNDED TTPS

\begin{tabular}{|c|c|c|c|c|c|}
\hline $\begin{array}{l}\text { PATENT APPLIED } \\
\text { FOR OR COPYAIGHT } \\
\text { ASSERTED? }\end{array}$ & $\begin{array}{l}\text { ANY OF THE FOLLOWING } \\
\text { OCCURRED? (PUBLICATION, ORAL } \\
\text { PRES., DISCLOSURE?) (GIVE DATE, } \\
\text { LOCATION) }\end{array}$ & $\begin{array}{l}\text { ANY PARTNERING } \\
\text { ARRANGEMENTS WITH } \\
\text { EXTERNAL ENTITIES? }\end{array}$ & $\begin{array}{l}\text { WHAT INDUSTRIES COULD } \\
\text { USE THIS TECHNOLOGY? }\end{array}$ & $\begin{array}{l}\text { LIST ANY COMPANIES } \\
\text { THAT HAVE EXPRESSED } \\
\text { AN INTEREST IN THIS } \\
\text { TECHNOLOGY? }\end{array}$ & $\begin{array}{l}\text { OTHER APPLICATIONS } \\
\text { OUTSIDE OF THIS RESEARCH } \\
\text { PROJECT }\end{array}$ \\
\hline & & & & & \\
\hline & & & & & \\
\hline & & & & & \\
\hline & & & & & \\
\hline & & & & & \\
\hline & & & & & \\
\hline & & & & & \\
\hline & & & & & \\
\hline & & & & & \\
\hline
\end{tabular}


Appendix C

Market Analysis

Statement of Work 
This Page Intentionally Left Blank 


\section{STATEMENT OF WORK}

\section{Purpose}

The purpose of this work is to facilitate the technology transfer and commercialization of Sandia National Laboratories-developed characterization, remediation, containment, and monitoring technologies for arid and semi-arid landfill and remediation sites. This work will focus on those SNL technologies funded by the Landfill Containment Focus Group, the Contaminant Plume Focus Group, the Characterization, Monitoring, and Sensor Technology Cross-Cutting Group. The project consists of two phases:

Phase I: Arid and Semi-Arid Landfill Remediation Site Market Assessment and Analysis

This phase will be an industry study to identify the DOE complex needs and market size in this area, followed by an analysis of the private sector needs and market size. This will consist of $a$. secondary literature search.

\section{Phase II: Individual Technology Market Assessment and Analysis}

The second phase of the project will be a series of technology specific market analyses to research specific environmental, mixed-waste landfill remediation technologies in relation to market factors.

The specific tasks to be achieved in each of these phases are outlined below. The purpose of these tasks is to give the Principal Investigators (PIs) a better understanding of landfill remediation as an industry and to identify the strengths/weaknesses, and opportunities/threats of each PI's specific technology by gathering past relevant information into an overview report.

PHASE I - Arid and Semi-Arid Landfill Remediation Site Market Assessment and Analysis

Tasks:

Task 1:

Complete Task 1 for (a) DOE complex; (b) state, county, city, Native American (nationwide); and (c) the US private sector. See attached diagram. Include all landfills (rubbage/garbage excluded). Complete each of the following sub tasks, developed chronologically:

Sub task a:

Identify the arid and semi-arid sites within the various market segments identified in the diagram (excluding international for this SOW). For example, first, the DOE complex including: Sandia National Laboratories, Los Alamos National Laboratories, Idaho National Engineering Laboratory, Hanford, Pantex, and NTS will be research. Second, state/county/city public and municipal type sites will be researched. Lastly, the private sector sites will be researched.

Sub task b:

Identify the break-down for each of the sites within these three markets (e.g., number of sites, estimated cost for clean-up, percent of total clean-up costs for that market vs. remediation industry, and the total size of all three market segments). 
Sub task c:

Investigate what is known about these sites (e.g., categories of waste products such as hazardous or mixed-waste, characterization status, size of each site (in cubic yards of dirt, square miles, or some other consistently used measurement), and percentage of each chemical at these sites).

Sub task d:

Discover what the key needs are at these sites (e.g., top problems occurring in this industry, and suggested solutions/alternatives to how characterization, remediation, and monitoring is performed.

Sub task e:

Answer specific questions about these sites. Specified below are categories of questions about the landfill industry.

\section{Total Market Size}

Using secondary literature, estimate the total landfill remediation, characterization, and monitoring market in dollars. Other relevant information in this section would include data on the total number of hazardous sites and mixed-waste sites, and a look at the geographical distribution of these sites.

\section{Marketing Research}

In this section, discover how one might disperse information about technologies that aid in landfill remediation, characterization, and monitoring. For instance, what are the major trade journals for this industry? Investigate possible avenues for presenting the technology that one might utilize such as trade shows, trade association newsletters, technical conferences.

\section{Characterization of Sites}

Characterize the various landfill sites according to owner/jurisdiction (i.e., state, private, DOE). Look at what types of waste (i.e., hazardous, VOCs, heavy metals, other chemical compounds) are in these sites. Include information on what the primary cause of problems are in the arid and semi-arid sites, and how many sites are leaking and why.

\section{Regulatory/Legal}

Answer questions of interest for this section including who regulates the various sites; what level of government is responsible for regulating the sites (i.e., federal, state, local); who are the contacts on the RODs (records of decision) which are data requirements for the closing of an existing site; and who mandates closure and then subsequently assesses and recommends clean-up technologies.

\section{Cost Comparison}

Supply a brief analysis of the economics of the situation. For instance, what the are the costs associated with a landfill? How does this cost compare to other disposal methods? 


\section{Competition}

Examine other potential markets for remediation technologies that may compete with the landfill application. For example, research into whether environmental technologies such as sensors and air/water quality monitoring equipment could be used in the mining, oil and gas industry, chemical producers industry, etc., would be useful.

\section{Task 2:}

For Task 2 compile a comprehensive report on Phase I activities that organizes answered questions. Extract information from secondary data sources only. If a question cannot be answered (due to lack of a secondary data source for example), include a statement explicitly stating this fact. Footnote quantitative information and provide a complete bibliography. Provide written analysis of these factors into a report which contains:

1. Executive Summary

2. Introduction

3. External Environmental Scan (which includes, but is not limited to, the regulatory environment, social environment demographics)

4. Industry Structure (e.g., manufacturers, software developers, environmental services: see attached diagram Industry Structure of MWLID)

5. Total Industry Size Measurements

6. Breakdown of Market Segments

7. SWOT Analysis (strength, weakness, opportunity, threat)

8. Assessment of the 4-Ps of the Industry (needed products and services, price ranges, information dispersal avenues, distribution channels)

9. List of Reference Materials from which Suppliers and Technical Users can be obtained."

10. Identify complimentary and/or alternative technologies

11. Forecasted Growth/Outlook

12. Conclusions and Recommendations

13. Sources (along with strengths and weaknesses of references)

14. Methodology (assumptions stated up front, research techniques, rational for the chosen research approach)

\section{Phase II - Individual Technology Market Analysis}

\section{Tasks:}

Task 1:

Review listed technologies and answer individual questions related to each. The technologies to be included in the individual market analyses include:

1. Magnetometer Towed Array

2. Measurement-While-Drilling

3. Electrokinetics

4. Fiber Optic TDR

5. Miniature Flow Probe Sensor

6. Seismic Borehole Technology

7. Landfill Characterization and Monitoring System

8. Dry Barrier Applications for Landfills

9. Subsurface Barrier Emplacement 
10. Advanced Landfill Cover Demonstration Technologies

11. Vadose Zone Verification and Monitoring Technology

Task 2:

Conduct patent/copyright/trademark, literature, and technical journal article searches. Reference corporate directories. List potential industry suppliers and users and possible avenues to disperse information about the technologies. Question business and scientific experts to get opinions on market potential.

Task 3:

Organize and analyze common technology market applications (see MWLID Class, Technology, and PI diagram).

Task 4: format:

Write short, individual market potential reports for each PI's technology following the given

1. Brief description of the technology and what it does

2. Market applications for the technology

3. List of reference materials from which suppliers and technical users can be obtained.

4. Name alternatives and/or complimentary technologies and their strengths/weaknesses

5. Comparison of the technology to existing solutions

6. Identification of major obstacles to the adoption of the technology

7. What it takes to make this technology transferable

8. The most/least attractive market applications

9. Analysis of the 4-Ps for this technology

10. Forecast of a technology transfer time frame

11. Question and Answer section addressing individual inventor's questions

Task 5:

Summarize, generalize, and prioritize the technologies according to marketability into one executive report, based on overall market and promise of individual technologies.

\section{The Deliverables}

1. Bi-monthly status reports to the SDA during the course of the contract in memo format indicating the status of work-in-process, progress to date, and questions that could not be answered given a lack of secondary sources on that topic.

2. Industry overview report in print and electronic form including tables, a bibliography of all source materials utilized, and contracts. (The print report will include copies of all source materials utilized.

3. Short (2-3 page) Individual Technology Market Analysis reports in print and electronic form of all the MWLID technologies listed under Task 1 of Phase 2.

4. A summary of the above two reports into one executive summary report with clear ranking of "best-hit" technologies and recommended actions. 
5. A cross-reference check of provided questions against the final reports to check for completeness and thoroughness of answers.

The above tasks for both Phase 1 and Phase 2 shall be completed no later than March 31, 1995.

*Note: No list of specific companies or individuals with which Sandia will potentially do business will be provided by the Contractor. 
This Page Intentionally Left Blank 


\section{Appendix D}

News Releases, Publications, Electronic Media Coverage Inititated, Facilitated, and Assisted Through TTP AL-2341-05 
This Page Intentionally Left Blank 


\section{News Releases Publications, Electronic Media Coverage Inititated, Facilitated, and Assisted Through TTP AL-2341-05}

\section{News Releases}

- "Sonic Drilling Demonstration at Sandia's MWLID" -4/22/93 (Sonic Drilling)

- "Mixed Waste Landfill Integrated Demonstration Field Days at Sandia National Laboratories" $-5 / 22 / 93$

- "Sandia, Navy, private industry work to develop system for magnetic imaging of hazardous waste sites" - 11/8/93 (MTA)

- "Santa Fe Company - Sandia Labs Collaboration Leads to New Environmental Product" 1/18/94 (SEAMISTM)

- "Sandia Wins Seven Awards to Take Top Honors in 1994 R\&D 100 Competition" - 7/25/94 (SEAMISTM included)

- "Sandia and Ditchwitch Explore Horizontal Drilling" - 9/16/93 (Directional Boring)

- "Sandia Develops Drill Cuttings Containment System for Drilling at Environmental Sites" 9/23/93 (DCCS)

- "Non-Invasive Electromagnetic Images Offer Unique Look at Landfill Subsurface" 10/27/94 (EM Imaging)

- "Unique Hazardous Waste Cleanup Demonstration Combines Heat and Vacuum Technologies" - 11/23/94 (TEVES)

\section{Publications}

\section{External}

- "Department of Energy to Hold Small-Firm Forum" $A B Q$ Journal, 8/93

- "Labs to Brief Companies on Environmental Work" $A B Q$ Journal, 8/93

- "Dune Buggy Waste Patrol" $A B Q$ Journal, 9/93 (MTA)

- "Well Liner Protects Sensors Monitoring Boreholes" Environmental Remediation Technology, 2/9/94 (SEAMTSTTM)

- "Landfill Cover Alternatives" HazTECH News, 2/10/94 (Dry Barriers)

- Sandia Helps Commercialize Environmental Sensor" SNL Technology Transfer Weekly, 2/14/94 (SEAMISTM)

- "Air Drilling Technique for Characterization Work" Weapons Complex Monitor, 2/28/94 (DCCS)

- "Horizontal Drilling Aids Sensing" Environmental Sensors, (this is a UK publication) 3/94 (Directional Boring, SEAMIST TM)

- "What Well-lined Wells will be Wearing" ESET: Environmental Science and Technology, 4/94 (SEAMIST)

- "Well liner Monitors Waste" Machine Design, 5/23/94 (SEAMISTTM)

- "Software Slashes Environmental Assessment Costs", ECON ,5/94 (PLUME) 
- "Characterization Costs, Time Saved with DOE Computer Program", Ground Water Monitor, 6/2/94 (PLUME)

- "Pollution Abatement: A 'Boring' Job" Outdoor News, 6/94 (Directional Boring)

- "Sensor-rich Well Liner Can Monitor Waste" American Ceramic Society Bulletin, 6/94 (SEAMIST ${ }^{\mathrm{T} M}$ )

- "Science's 'Oscar' Winners" ABQ Tribune, 7/26/94 (SEAMTSTTM)

- "Labs' Inventions Take Awards" ABQ Journal; 7/312/94 (SEAMISTTM)

- "Sandia Again Takes Top Honors with Seven R \& D 100 Awards" SNL Lab News, 7/94 (SEAMIST TM)

- "Horizontal environmental Well Installations" Trenchless Technology, 7/94 (Directional Boring)

- "Remediation and Directional Boring" Trenchless Technology, 7/94 (Directional Boring)

- "SNL Demonstrates Mixed Waste Landfill Technologies" TIE Quarterly, Fall 94 (MWLID)

- "New Database May Help Firms Get Federal Jobs" Albuquerque Journal, 11/7/94

- "Where Does Trenchless Go From Here?" Construction Equipment, 2/95 (Directional Boring)

- "Tracking Pollutants Underground" Mechanical Engineering, 3/95 (RIM)

- "Technique Vaporizes Contaminants" AAPG Division of Environmental Geosciences Reporter, 1/96 (TEVES)

\section{SANDIA Reports}

- J.C. Stormont, M.D. Ankeny, M.E. Burkhard, M.K. Tansey, and J.A. Kelsey, Assessment of an Active Dry Barrier for a Landfill Cover System, SAND-94-0301, Sandia National Laboratories, Albuquerque, NM, February, 1994.

- B.P. Dwyer. Feasibility of Permeation Grouting for Constructing Subsurface Barriers, SAND-940786, Sandia National Laboratories, Albuquerque, NM, April 1994.

- Carl Morris, Bruce Thompson, and John Stormont, Assessment of Dry Barriers for Containment of Mobile Constituents in the Unstaturated Zone, SAND-94-2094, Sandia National Laboratories, Albuquerque, NM, January, 1995.

- Cecelia V. Williams and Ralph Gruebel, Off-Site Demonstrations for MWLID Technologies, SAND-94-2340, Sandia National Laboratories, Albuquerque, NM, April, 1995.

- J. Phelan, B. Reavis, and W. Cheng, Passive Soil Venting at the Chemical Waste Landfill Site at Sandia National Laboratories, Albuquerque New Mexico, SAND-95-0776, Sandia National Laboratories, Albuquerque, NM, May, 1995.

- R.J. Floran, G.E. Bujewski, and R.L. Johnson, Adaptive Sampling Approach to Environmental Site Characterization: Phase I Demonstration, SAND-95-0070, Sandia National Laboratories, Albuquerque, NM, July 1995.

- Rudy Mataluccie, Charlene Esparza-Baca, Richard Jimenez, and Scott Hitchcock, Status and Export Potential of DOE's Mixed Waste Landfill Integrated Demonstration (MNLID) Technologies, Sandia National Laboratories, Albuquerque, NM, February 1995. (draft) 


\section{Internal}

- "Sonic Drilling Rig Hits Heavy Metal at Closed Landfill" SNL Lab Newws, 6/93 (Sonic Drilling)

- "It was a Real 'Field Day' for ER Technologies" SNL Lab News, 6/93

- "Labs' Mixed Waste Landfill Project Praised by Governor King" SNL Lab News, 9/93

- "Environmental Bottom Line Draws 200", SNL Lab News, 9/93

- "SEAMISTTM: Faster, Safer Site Characterization" Energy and Environment, 10/93 (SEAMIST ${ }^{\mathrm{M} M}$ )

- "Small Business Attends the Environmental Bottom Line" Environmental Technologies, 11/93

- "Sandia Project on Western Governors Association's 'Short List"', The EyE Newosletter: Energy and Environment, 1/94 (ALCD)

- "Toxic Waste" Sandia Technology: Engineering and Science Accomplishments, 2/94 (MTA)

- "Sensor-rich Well Liner Commercialized for Waste Monitoring" Sandia Science News, 3.94 (SEAMIST ${ }^{\text {TM }}$ )

- "Seismic Images Monitor Experiment" The EyE Newsletter: Energy and Environment, 4/94 (Subsurface Barriers)

- "Helping DOE's Cleanup Efforts: Commercialization Planning Workshops" The EyE Newsletter: Energy and Environment, 5/94

- "Improved Technology Performance Demonstrated" The EyE Newsletter: Energy and Environment, 7/94 (TEVES)

- "Paper Wins Award for Methodology That Promotes Cost-Effective Designs" The EyE Newsletter: Energy and Environment, 7/94 (Dry Barriers)

- "New Technology Receives the 'Oscar of Invention' -an R\&D 100 Award" The EyE Newsletter: Energy and Environment, 8/94 (SEAMISTTM)

- "'Underground Oven' Bakes Soil in Area 3 Landfill" Sandia Lab News 11/11/94 (TEVES)

- "Chemical Waste Landfill Hosts Another Demonstration" The EyE Newosletter: Energy and Environment, 11/94 (TEVES)

- "Swoosh! New System Vacuums Up Drill Cuttings" Energy and Environment 11/94 (DCCS)

- "Containing Wastes and Costs" Sandia Technology, 2/95 (Dry Barriers, Subsurface Barriers)

- "Systems Approach Saves ER Costs" The EyE Newsletter: Energy and Environment, 3/95. (LAMS)

- "Non-invasive Electomagnetic Images Offer Unique Look at Landfill Subsurface" Sandia Science News (EM Imaging)

\section{Electronic Media Coverage}

- MWLID Earth Day Site Tour - KOAT TV News - 4/17/93

- Magnetometer Towed Array Demonstration - KOAT TV News - 6/10, 9/10, 1993

- Magnetometer Towed Array - KOB TV News - 9/28/93

- Hybrid Directional Boring - Today's Environment - CNBC-9/3/94

- Hybrid Directional Boring - Today's Environment - Discovery Channel - 9/7/94

- SEAMISTMM - CNN Headline News - 9/22/94 
This Page Intentionally Left Blank 


\title{
Appendix E
}

\author{
Mixed Waste Landfill Integrated Demonstration \\ Technology Transfer/Commercialization Involvement
}


This Page Intentionally Left Blank 


\section{Mixed Waste Landfill Integrated Demonstration Technology Transfer/Commercialization Involvement}

\section{Poster Sessions}

- Waste Retrieval, Treatment and Processing: (Mar 1993) The poster session"Technology Integration at the Mixed Waste Landfill Integrated Demonstration (MWLID)" was presented. In addition, the Thermal Enhance Vapor Extraction System (TEVES) was featured during a technical session.

- Winrock Mall: (Aug 1993) The MWLID poster, which showcases technology development efforts in the areas of characterization, monitoring, remediation, containment, and technology transfer successes, was displayed for a local audience.

- Atomic Museum: (Aug 1993) The MWLID poster, which showcases technology development efforts in the areas of characterization, monitoring, remediation, containment, and technology transfer successes, was displayed for a local audience.

- Outreach to Industry: Partnerships for the Future: (Jan 1994) The MWLID's efforts in landfill characterization and monitoring, remediation, and containment technology development, as well as its commercialization successes, were on exhibit at the two-day poster session. Interest in the MWLID's efforts came from the private as well as from the governmental sector. The Outreach to Industry was a technical information exchange meeting with industry on environmental restoration needs in the northwest United States co-sponsored by the U.S. Department of Energy (DOE) Environmental Restoration and Waste Management Office of Science and Technology (OST) and Office of Environmental Restoration.

- Waste Management '94: "High Level Waste, Low Level Waste, Mixed Wastes and Environmental Restoration - Working Towards A Cleaner Environment": (Feb 1994) A poster session paper entitled "The Mixed Waste Landfill Integrated Demonstration" was presented. Also, the MWLID's poster was on exhibit at the three-day Technical Exhibition. Interest in the MWLID's efforts came from private, university and government sectors. The meeting was sponsored by University of Arizona, DOE, New Mexico State University (NMSU), the Waste-management Education and Research Consortium (WERC), and numerous other organizations.

- Sandia National Laboratories (SNL) Earth Day Activities: (May 1994) The MWLID poster, which showcases technology development efforts in the areas of characterization, monitoring, remediation, containment, and technology transfer successes, was displayed.

- Advanced Manufacturing Day at the Ideas in Science and Electronics, ISE,'94 Exposition \& Symposium: (May 1994) The MWLID participated in the exposition and symposium sponsored by the Institute of Electrical \& Electronics Engineers (IEEE), Albuquerque Section, and the Rio Grande Chapter of Electronics Representatives Association (ERA). The MWLID poster was presented. The purpose of the conference was to share recent 
developments in technology, science, electronics, and advanced manufacturing techniques with industry.

- Progress Through Partnerships Exhibition at Hanford Summit II: (Jun 1994) Hanford Summit II is a national forum on the environment, technology, and the economy. The mission of Summit II is to build upon existing scientific, technical, and engineering innovations to clean up Hanford and to serve as model to ":ake cleanup better, faster, cheaper, and safer at sites across the nation. The meeting $\cdot$, ss an interactive forum among federal, state, and local governments, Hanford employees, citizens of Washington, and Native American tribal representatives. The MWLID poster was displayed at the exhibition.

- Small Business Association-National Contractors Management Association 1994 Environmental Remediation Opportunities Conference: (Jul 1994) The MWLID poster was displayed. The MWLID gave out more than 100 registration forms for the Los Alamos National Laboratory (LANL)-SNL Environmental Communications Database.

- Spectrum '94: (Aug 1994) The MWLID poster and a poster paper entitled "An Overview of the Mixed Waste Landfill Integrated Demonstration" were presented at the international technical meetings. The program was designed to facilitate information exchange between scientists and engineers and to explore changes in the environmental field.

- Waste Management '95: (Feb 1995) The MWLID poster was displayed. Significant interest was shown in containment activities including the Alternative Landfill Cover Demonstration (ALCD), the dry barrier concept, and subsurface barriers.

- National Ground Water Association Outdoor Action Conference: (May 1995) The MWLID poster showcasing technology development efforts was displayed. Demonstrations were conducted for SEAMIST TM, Cross Borehole Electromagnetic Imaging as Radio Imaging Method (RIM), and ReconantSonic ${ }^{\mathrm{M}}$ drilling technology.

- Spectrum '95: (Aug 1995) The MWLID poster was presented at the international technical meetings.

\section{Tours}

- MWLID Field Days: (May 1993) Three Field Days were held to provide an overview of the program and allow stakeholder evaluation through interaction. The first Field Day focused on the public, while the second and third respectively, focused on industry and regulators/government officials. DOE-Albuquerque Operations Office and DOE-Kirtland Area Office (KAO) representatives participated all three days. The format of the Field Days included an Environmental Management Integrated Programs/Integrated Demonstrations overview, a presentation on the MWLID, a demonstration of ProTech, a field tour, and a luncheon speaker. Additionally, the MWLID presented a poster session that included the Landfill Assesment and Monitoring System (LAMS), SEAMISTTM, TEVES, dry barriers, Stripping Analysis, technology integration, and a demonstration of SitePlanner ${ }^{\mathrm{TM}}$. The field tour included SEAMIST TM, TEVES, dry barriers, Stripping Analysis, the Drill Cuttings Containment System (DCCS), monitored wells, and a launch point for sonic directional 
boreholes. Speakers provided information on public participation, transfer and commercialization of technologies being developed, and joint environmental restoration research between SNL and LANL. Initial feedback from participants was very positive. A memo to the Field Tours Team said the turnout for the Field Days was the highest for any public involvement activities of this type for SNL/DOE/KAO.

- Magnetometer Towed Array at Technical Area II: (Sep 1993) Observers withnessed the demonstration of GEO-CENTERS' commercial version of the Surface Towed Ordnance Locator System (STOLSTM) conducted at the KAFB RB-11 landfill. The survey was completed in less than two hours at a rate of about one acre per half hour.

- EPA Engineering Forum: (Dec 1993) EPA staff attending the EPA's Engineering Forum in Santa Fe toured the Chemical Waste Landfill. Featured technologies at the meeting and/or site tour included TEVES, dry barriers, SEAMISTTM, and subsurface barriers.

- UMTRA Tour: (Jun 1994) Field tours of MWLID activities were conducted for the Uranium Mill Tailings Remedial Action (UMTRA) Project and the Washington Technology publication. Featured technologies include TEVES, electrokinetic remediation, dry barriers, Cross Borehole Electromagnetic Imaging, and theVadose Zone Montoring System. Directional drilling and directional sonic drilling boreholes were also featured.

- Japanese Tour: (Feb 1995) Three representatives from Japan interested in the U.S. laboratories and potential areas of mutual interest to the U.S. and Japan toured SNL. The Director of the Environmental Programs Center gave a presentation on the Environmental Technologies Department. The Manager of the Environmental Restoration Technologies Department gave a presentation of Environmental Restoration. The MWLID/SNL-ERT poster was also displayed. It emphasized LAMS, TEVES, electokinetic remediation, ALCD, the dry barriers, technology transfer successes, and industry participation.

- Richard Guimond Tour: (Mar 1995) The Principal Deputy Assistant Secretary from Environmental Restoration and Waste Management and DOE and SNL representatives were given a familiarization tour of the MWLID. Technologies featured include TEVES, dry barriers, subsurface barriers, and SEAMIST ${ }^{\mathrm{TM}}$. Participants also discuseed the upcoming ALCD demonstration.

- Landfill Stabilization Focus Area Management Team and Product Line Managers: (Mar 1995) Approximately 10 people from the Landfill Stabilization Focus Area management teams toured field demonstrations of the MWLID. Featured technologies included: electrokinetic remediation, TEVES, ALCD, and subsurface barriers.

- USGS Tour: (May 1995) About 100 people toured field demonstrations of the MWLID as part of the National Meeting of U.S. Geologic Survey employees. Featured technologies included: electrokinetic remediation, TEVES, ALCD, and subsurface barriers.

- Advanced Landfill Cover Demonstration WGA Open House: (Sep 1995) Approximately 100 people attended a Tour of the ALCD Construction Site where Principal Investigator Steve Dwyer, SNL briefed the audience on Construction Activities at the Site. Featured technologies included: Containment Technologies - Permeable Barriers, Subsurface Barriers, and the Smart Geomembrane; Characterization Technologies - 
MAPER, Cross Borehole Electromagnetic Imaging, and Environmental MeasurementWhile-Drilling; and Remediation Technologies - Electrokinetics, and In-Situ Gaseous Reduction System.

- Gerald Boyd Tour (1996)

Gerald Boyd, EM-50 associate deputy assistant secretary, received a tour of the SNL-ERT demonstration sites and was given a presentation on the status of ongoing activities by development principal investigators.

\section{Presentations}

- EM-52 Technology Integration Program Review: (Apr 1993, C. Williams) An overview of Mixed Waste Landfill Integrated Demonstration activities was presented including involvement with ProTech, technical support groups, and industry partners.

- Environmental Bottom Line: (Aug 1993, J. Woodward) SNL's environmental programs were presented at the environmental briefing for small businesses designed to inform participants of the business opportunities in the DOE Environmental Restoration and Waste Management programs at SNL and LANL.

- Environmental Small Business Workshop: Bridges to Environmental Opportunities: (Nov 1993, C. Williams) A presentation on the MWLID and mixed waste issues was made at the Hazardous and Mixed Waste Opportunities session. The workshop informed small businesses of procurement, technology development, and technology transfer opportunities for environmental management services and materials at DOE's laboratories.

- EM-52 Technology Integration Mid-Year Program Review: (Mar 1994, C. Williams) A review of technology integration activities of the past year (including the Field Days, the Environmental Bottom Line, materials development, public and regulatory involvement, and technology transfer successes) was presented. The critical issues of OST credit, regulatory approval, and commercialization planning for the OST/Environmental Management-developed technologies were addressed. The lessons learned include the need for early public involvement and benefits reaped from teaming and advanced planning with experts within SNL (i.e., public relations, media relations, technical writers, technology transfer specialists, etc.).

- Fourth Annual WERC Environmental Restoration Conference: (May 1994, C. Williams, T. Burford) Two papers entitled "An Overview of the Mixed Waste Landfill Integrated Demonstration" and "Technology Development Opportunities in the MWLID" were presented.

- Federal Environmental Restoration III and Waste Minimization II: (May 1994, C. Williams, T. Burford) "The Mixed Waste Landfill Integrated Demonstration: Metrics for Technology Development and Technology Transfer Successes" was presented to an audience that included government, management and operating contractors, and industry representatives. 
- Soil Remediation Innovative Technology and Contracting Office: (May 1994, C. Williams) The paper "Technology Transfer Opportunities in Sandia's Mixed Waste Landfill Integrated Demonstration" was presented. This conference was specifically aimed at industry and addressing its needs.

- Brookhaven National Laboratory Landfill Characterization Workshop: (Oct 1994, C. Williams, R. Floran, and D. Betsili) The MWLID technologies suitable for characterization and remediation of disposal pits at BNL were presented. Presentations included: SitePlanner; characterization and monitoring technologies; and remediation and containment technologies.

- New Mexico Hazardous Waste Management Conference and Exhibition: (Mar 1995, C. Williams, R. Gruebel) The paper "Identification of Potential Sites for Offsite Demonstration of MWLID-developed Technologies" was presented.

- 5th Annual Waste-management Education and Research (WERC).Development Conference: (Apr 1995, C. Williams, R. Gruebel) "Site Contaminant Technololgy Matching for Offsite Demonstrations of MWLID-developed technologies" was presented.

- North American No-Dig '95: Conference (May 1995, SNL-ERT reprentative) The paper "Environmental Measurement-While-Drilling System for Real-time Field Screening of Contaminants" was presented.

\section{Participation}

- Regional Environmental Business Exchange: (Nov 1993) The MWLID, its mission, and opportunities were informally presented at the workshop, which shared with businesses the problems and opportunities available in Westinghouse Hanford Operations environmental cleanup.

- Fifth Annual Weapons Complex Monitor Applied Research and Technology Colloguium: (Apr '93) An MWLID representative particpated in the WGA Mixed Waste DOIT Working Group Meeting as the technology transfer and public participation liaison for the MWLID and CMST-IP Focus Area technology proprosals review.

\section{Telephone Referrals}

Telephone contacts average three to five each week. These include referrals by the Technology Transfer Office and the Procurement Office. The contacting businesses are predominately interested in environmental restoration activities. The SNL-ERT continues the MWLID's former role of matching industry expertise with the appropriate contact in the Environmental Restoration area. 
This Page Intentionally Left Blank 


\section{Appendix F}

\section{Development Partners}


This Page Intentionally Left Blank 


\section{FY94 Development Partners}

National Laboratories

- Argonne National Laboratory

- Brookhaven National Laboratory

- Idaho National Engineering Laboratory

- Lawrence Livermore National Laboratory

- Los Alamos National Laboratory

- Lawrence Berkeley National Laboratory

- Pacific Northwest Laboratory

Research Laboratories

- EPA Environmental Monitoring Systems Laboratory

- Department of Agriculture - Agriculture Research Station

- Navy, Naval Civil Engineering Laboratory

- Naval Research Laboratory

- Illinois Institute of Technology Research Institute

- Westinghouse-Hanford Operations

Universities

- Colorado State University

- New Mexico State University

- University of California Santa Barbara

- University of Houston

- University of New Mexico

- University of Texas - Austin

- University of Washington

Industry Partners

- Advanced Analytical, Inc.

- Charles Machine Works, Inc.

- Chem-Nuclear Geotech (now Rust Geotech)

- Consolve, Inc.

- Daniel B. Stephens and Associates, Inc.

- DuPont

- GEO-CENTERS, Inc.

- Guzzler, Inc.

- Pfizer

- Physical Scienc Laboratory (PSL) at New Mexico State University

- Science and Engineering Associates, Inc.

- Scitek Corporation

- Spectrace Instruments

- Stolar, Inc.

- Tech Reps, Inc.

- Troxler Electronics Laboratory

- Viking Instruments 
- Water Development Corporation

Government Agencies

- Air Force, Hill \& Kirtland Air Force Bases

- Department of Energy

- Environmental Protection Agency

- New Mexico Environment Department

- Western Governors' Association

\section{FY95 Development Partners}

National Laboratories

- Idaho National Engineering Laboratory

- Pacific Northwest Laboratory

Research Laboratories

- Department of Agriculture - Agriculture Research Station

- Naval Research Laboratory

- Illinois Institute of Technology Research Institute

- Westinghouse-Hanford Operations

\section{Universities}

- Colorado State University.

- New Mexico State University

- University of New Mexico

- University of Texas - Austin

\section{Industry Partners}

- Charles Machine Works, Inc.

- Daniel B. Stephens and Associates, Inc.

- GEO-CENTERS, Inc.

- Science and Engineering Associates, Inc.

- Tech Reps, Inc.

- Trautwein Soil Testing Company

- Troxler Electronics Laboratory

- SAT-UNSAT, Inc.

Government Agencies

- Environmental Protection Agency

- Department of Agriculture

- New Mexico Environment Department

- Western Governors' Association

- All Indian Pueblo Council 
Appendix $\mathbf{G}$

Commercialization Plans 
This Page Intentionally Left Blank 


\section{Commercialization Plans}

Commercialization Plans completed as a result of two Commercialization Planning Workshops (CPWs $\left.{ }^{\mathrm{TM}}\right)$ include:

- Cecelia V. Williams, SNL: TTP \#AL2-2-11-15

Inverting Membrane Borehole Instrumentation Techniques

SEAMISTMM is completed and implemented. Eastman Cherrington Environmental is marketing the SEAMIST ${ }^{T M}$ system.

- Robert Wemple, SNL: TTP \#AL2-2-11-16

Hybrid Directional Boring and Horizontal Logging

Charles Machine Works-Ditch Witch has made a corporate decision to commence largescale commercialization. Their commercialization efforts are extending into international markets.

- Robert Johnson, ANL: TTP \#CH2-2-11-02

Optimization of Sampling Strategies for Containment Delineation and Risk Minimization The plan is being implemented. ConSolve is marketing SitePlanner ${ }^{\mathrm{TM}}$ and PLUME as well as SiteView ${ }^{\mathrm{TM}}$, a spin-off of the software origninally developed as part of this TTP.

- John Cochran, SNL: TTP \#AL2-3-10-03 Magnetometer Towed Array (MTA) GEO-CENTERS is extending the use of this technology to international markets.

- Khris Olsen, PNL: TTP \#RL3-2-11-12, Stripping Analysis Radiometer America Corp. commercialized Stripping Analysis.

- David Borns, SNL: TTP \#AL2-2-11-23

Cross Borehole Electromagnetic Imaging Physical Science Laboratory at New Mexico State University is marketing this technology internationally to the mining and oil industries as Radio Imaging Method (RIM).

- Gregory C. Frye, SNL: TTP\#AL2-2-11-04

Portable Acoustic Wave Sensor (PAWS)

The Plan is complete, and negotiations are ongoing to finalize industrial partnerships.

Plans drafted as a result of holding two CPWs:

- Ken Bostick, LANL: TTP \#AL1-3-10-01

Prototype Decision Support/Cover System

- Wayne Hansen, LANL: TTP \#AL1-2-12-11

Migration Barrier Covers for Mixed Waste 
- David Betsill, SNL: TTP \#AL2-2-11-07 Landfill Assessment and Monitoring System (LAMS)

- Robert Floran, SNL: TTP \#AL2-4-10-07 Environmental Measurement While Drilling (EMWD)

- Steve Dwyer, SNL: TTP \#AL2-4-10-03 Alternative Landfill Cover Demonstration

- Brian Dwyer, SNL: TTP \#AL 2-3-10-04 Subsurface Barrier Emplacement

- Larry Kukacka, BNL: TTP \#CH3-2-11-01, In situ Containment and Stabilization of Buried Waste

- Greg Elbring, SNL: TTP \#AL2-4-10-02 Seismic Borehole Technology

- Ken Bostick, LANL: TTP \#AL1-4-10-01 Post Closure Monitoring Technology

- Robert Knowlton, SNL: TTP \#AL2-4-10-10 Fiber Optic TDR

- George Laguna, SNL: TTP \#AL2-4-10-09 Miniature Flow Probe Sensor

- Eric Lindgren, SNL: TTP \#AL2-4-10-01 Electrokinetic Remediation

- Chet Shepard, PNL: TTP \#RL3-2-11-13 X-ray Fluorescence Detection of Heavy Metal Contaminants

- Jim Sisson, INEL: TTP \#ID1-4-10-02, Borehole Permeameter

- John Stormont, SNL: TTP \#AL-2310-02 Dry Barrier Applications for Landfills

Three MWLID PIs/technologies did not participate in a CPWTM:

- James Phelan, SNL: TTP \#AL-2211-21 Thermal Enhanced Vapor Extraction System

- Willis Stewart, SNL: TTP \#RL-4410-10 Verification of Subsurface Barriers

- Cecelia V. Williams, SNL: TTP \#AL-2211-15 Deep Vadose Zone Monitoring Although a commercialization plan was not developed for this system, Science and Engineering Associates, Inc., is marketing a commercial version called MultiScan ${ }^{\mathrm{TM}}$. 


\begin{abstract}
Appendix $\mathrm{H}$
Evaluation Results

Commercialization Planning Workshops at Sandia
\end{abstract}


This Page Intentionally Left Blank 


\section{Evaluation Results Commercialization Planning Workshops at Sandia}

March 28-31 and May 16-20, 1994

Rating based on excellent equal to 3

1. The quality and relevance of information presented was

Observers PIs

2. The quality of presentation and expertise level of Mohawk Faculty was $2.8 \quad 2.6$

3. In support of DOE/OST's technology commercialization goals the content of the workshop was

3.0

4. My commercialization prospects are

3.0

5. I consider the investment of my time in this workshop

N/A 2.3

6. I rate the overall workshop

$3.0 \quad 2.3$

7. The workshop: () exceeded () met () was below my expectations

$2.7 \quad 2.4$

$2.2 \quad 2.5$

8. Would you recommend this workshop to:

Observers

PIs

a fellow PI

$\mathbf{Y} \mathbf{N}$

$\begin{array}{lll}\mathbf{N} & \mathbf{N} & \mathbf{N} / \mathbf{A}\end{array}$

your management

182

4

2

$15 \quad 5$

6

9. Is the action plan you generated a valuable tool and relevant to your efforts?

10. Do you feel you have greater knowledge of market analysis and its importance?

11. What follow-up support do you need to succeed?

PIs:

- Review and independent help with actual commercialization of projects

- Did not budget funding for commercialization

- Funding to make commercialization a recognized activity as part of the TTP

- FY94 funding for this activity not available to provide market analysis

- SNL Legal and Tech Transfer support and guidance

- LANL Industrial Relations Market Analysis 
- Legal, market analysis

- Re-evaluation in approximately 1 year

- Business planning

- Help on establishing intellectual property rights

- Support in market analysis and identification of partners

- Market analysis

- Support from Sandia's Legal and Technology Transfer groups to do patenting, licensing, copyrighting

- Identify resources (funding and personnel) to help put marketing plan into action

- Opportunity to work with Intelectual Property personnel and PML lawyer

\section{Observers:}

- Availability of faculty to discuss plans after PI meets with private industry/management

\section{Additional comments:}

Pls:

- Material presented was not focused on how the National Labs operate

- Presentations by Mohawk Research somewhat informative and helpful

- Information presented could have been condensed into a two-day class

- "Source of Capital" section could be deleted since it is not applicable to our activities

- Team leader for Mohawk Research was somewhat abrupt to several individuals in the class during the workshop

- Would welcome more specific suggestions for gaining an understanding of the market/potential markets

- These kinds of workshops will push SNL into the real world

- Would suggest making the workshop more SNL-specific, perhaps a 1 hour presentation giving an overview of legal and tech transfer services available at the $\mathrm{Iab}$ (D. Belasich might be a good candidate)

- Dinner should have been earlier

- Initial interviews could have been scheduled better from a time perspective

- Faculty was intelligent and supportive but could have been MUCH more effective had they had a better idea of what the MWLID is and does prior to starting the workshop

- Tailoring materials, overheads, discussions, etc. to our environment (MWLID \& Lab) would have moved this workshop into the excellent (or beyond) category 
- Having all attendees stay at a facility removed from home/office would be beneficial

- Possibly allow a more focused approach and maybe shorten the workshop by a day

- More detail on Intellectual Property Rights would have been useful

- Liked it and got a great deal out of this

- Could use more pre-meeting exercise/information

- Break up presentation time with activities toward Commercialization Plan

- Follow outline of Commercialization Plan throughout

- The workshop time could have been condensed. Some of the discussion sessions could have been greatly reduced or have larger groups

- Expected, since the faculty spent a lot of time reviewing our materials, that we would have gotten more constructive feedback on commercialization activities

- Many of the notes are too orientated for entrepreneuership which $90 \%$ of lab staff do not care for

- The afternoon one-on-ones are too long. Perhaps only half the staff should be included for each student

\section{Observers:}

- Faculty diversity and expertise outstanding: Industrial, academic \& governmental engineering, scientific, legal, patent, business, financial, etc; each has over 20 years

- Site selection (off-site) was excellent and is key to the "team building" and free "University form" idea exchange

- Should use results of this survey and the resulting Commercialization Plans to get more funding for tech transfer activities specific to each project

- This is exactly the type of education PIs and all technically oriented people at Sandia are in dire need of. The new focus of the labs requires re-educating the technical personnel to give them some insights to the business issues. If they don't figure this out they may not survive in the coming years

- Make sure participants are aware of the requirements and expectations of the workshop

- The input from the local sponsor during faculty meetings is invaluable

- To the extent possible, faculty should be knowledgeable of the projects and mechanisms in place, (resources) that may be available to the PI

- Mechanics - please note room names on the agenda for each session

- Food was great, hotel was fine

- Try to minimize idle time for PIs on the first day between individual interviews and overview presentations 
This Page Intentionally Left Blank 


\section{Appendix I}

\section{Technology Developer and Stakeholder Meetings}


This Page Intentionally Left Blank 


\section{Technology Developer and Stakeholder Meetings}

- WGA-DOIT SIT Meeting for the ALCD, April 1995. This meeting focused on finalizing the Stakeholder Involvement Plan. The plan included: 1) Plan Objective-Integration of Stakeholder Outreach into the ALCD project; 2) Historical Background; 3) Baseline Principles and Goals; 4) SNL Site Implementation Team Stakeholder Participation Principles; 5) Timelines and Additional Specifics on Key Elements of the SNL Site Implementation Team Stakeholder Outreach Efforts. The plan was submitted to the Mixed Waste WGA-DOIT committee for review and approval.

- Innovative Environmental Technologies Conference and Demonstration, May 20 - 23, 1995 (at the National Mine Safety and Health Academy, Beckley, West Virginia). "Hand's-on" demonstration of the Magnetometer Towed Array technology, requested by C.W. Frank, Deputy Asst. Secy. for Technology Development.

- WGA-DOIT SIT Stakeholder Meeting, June 1995. Discussions regarding the Alternative Landfill Cover Demonstration.

- Isleta Pueblo and SNL-ERT Meeting, June 1995. Isleta Pueblo requested technical assistance on its landfill closure plan.

- Decontamination \& Decomissioning and US DOE Technology Infromation Exchange Meeting, June 1995. SNL-ERT PIs presented their work on Environmental Measurement-WhileDrilling, Electrokinetics and In-Situ Gaseous Remediation System to the Japan Ministry of International Trade \& Industry and the Japan Nuclear Power Engineering Corp.

- Meetings with PIs from LSFA, PFA and CMST Cross-Cutting Program, June 1995. PIs ascertained their specific needs in the technology-specific portion of the market analysis.

- WGA-DOIT SIT Stakeholder Meeting for the ALCD, June 1995. This meeting focused on public involvement and interstate regulatory cooperation. Attendees included technical, regulatory and public stakeholders $(\sim 70)$ from several southwestern states. The morning session included introductory remarks by Garry King, DOIT Mixed Waste Working Group Chair, and Ginger Swartz, DOIT Process Administrator for WGA, and a presentation on the ALCD by Steve Dwyer, the PI.

The format of the afternoon session was a panel discussion on technical, regulatory, and public issues. The panelists included regulators from the EPA and the New Mexico Environment Department; technical, academic and industry experts; and public stakeholders. The general consensus was that this was a good first step with many of the comments focusing on global regulatory and public interface issues. The project was seen in a very positive light by technical, regulatory, and public stakeholders. Questions were raised on how the project would aid regulators and the regulated communities, the effectiveness of alternative covers, cost-benefit analysis, and public access to information. Follow-on meetings were to include a site tour during the construction phase of the project. 
- Isleta Pueblo and SNL-ERT Meeting, July 1995. Isleta Pueblo requested technical assistance on its landfill closure plan.

- WGA-DOIT SIT Meeting for the ALCD, July 1995. This meeting focused on planning a Stakeholder Site Tour of the Alternative Landfill Cover Demonstration in September 1995 during construction of Phase I landfill covers.

- MWLID Field Days, May, 1993. (See page 89, "Tours").

- Public Involvement Working Group Meeting, August 31, 1995. Discussed Public Involvement calendar of events; the Citizens' Advisory Board handling process; Hearing of the Air Quality Control Board about the DOE exemption from Regulation No. 5. 


\section{Appendix J}

\section{Alternative Landfill Demonstration Team and Interested Parties}


This Page Intentionally Left Blank 


\section{Alternative Landfill Cover Demonstration Team and Interested Parties}

Steve Baca

Sandia National Laboratories

P.O. Box 5800, NM 1313

Albuquerque, NM 87185

Ron Bhada

Waste-Management Education Research Consortium

P.O. Box 30001, Dept WERC

Las Cruces, NM 88003

Skip Chamberlain

Department of Energy - Headquarters

EM541, Trevion II

Washington, DC 20585

Robert S. Dinwiddie

Hazardous \& Radioactive Materials Bureau

New Mexico Environment Department

P.O. Box 26110

Santa Fe, NM 87502

Karen Douglas

Department of Energy - Albuquerque

P.O. Box 5400

Albuquerque, NM 87185-5400

Steve Dwyer

Sandia National Laboratories

Org. 6621, MS 0719

Albuquerque, NM 87185

Jim Firkins

NM Energy, Minerals and Natural Resources Department

2040 South Pacheco

Santa Fe, NM 87505

Critz George

Brown \& Root Environmental

2300 Buena Vista SE, Suite 110

Albuquerque, NM 87106

Margaret Gover

National Tribal Environmental Council

1225 Rio Grande NW

Albuquerque, NM 87104

Michael Guerrero

Southwest Organizing Project

211 10th St., SW

Albuquerque, NM 87102

Barbara Hoditschek

Hazardous \& Radioactive Materials Bureau

New Mexico Environment Department

P.O. Box 26110

Santa Fe, NM 87502
Gary King

Mixed Waste Work Group

P.O. Box 40

Moriarty, NM 87506

Stephanie Kruse

Hazardous \& Radioactive Materials Bureau

New Mexico Environment Department

P.O. Box 26110

Santa Fe, NM 87502

Jennifer Nelson

Sandia National Laboratories

Org. 6621, MS 0719

Albuquerque, NM 87185

Paul Robinson

Southwest Research \& Information Center

P.O. Box 4524

Albuquerque, NM 87106

Blaine Sanchez

Isleta Tribe

P.O. Box 1270

Isleta Pueblo, NM 87022

Heidi Snow

NM Energy, Minerals and Natural Resources Department

2400 South Pacheco

Santa Fe, NM 87505

Jay Sorensson

Sierra Club

2800 Charleston, NE

Albuquerque, NM 87110

Richard Stafford

Solid Waste Bureau

New Mexico Environmental Department

P.O. Box 26110

Santa Fe, NM 87502

Ginger Swartz

Western Governors' Association

600 17th Street

Suite 1705 South Tower

Denver, CO 80202-5452

Chris Wentz

NM Energy, Minerals and Natural Resources Department

2040 South Pacheco

Santa Fe, NM 87505

Cecelia Williams

Sandia National Laboratories

Org. 6621, MS 0719

Albuquerque, NM 87185 
This Page Intentionally Left Blank 


\section{Appendix K}

Plan for Stakeholder Participation in the Alternative Landfill Cover Demonstration Project 
This Page Intentionally Left Blank 


\section{PlaAn for Stakeholder Participation IN THE Alternative LANDFLl COVER DEMONSTRATION PROJECT}

This document sets forth the Alternative Landfill Cover Demonstration Team's plan for stakeholder outreach and participation. It provides a discussion of the plan's objectives, summarizes the Alternative Landfill Cover Demonstration (ALCD) taking place at Sandia National Laboratories (SNL) and addresses the risks and significance of the project. The document also sets forth stakeholder participation principles specific to this demonstration and outlines specific stakeholder outreach and participation activities the team intends to implement.

The Principles for Stakeholder Participation in the Alternative Landfill Cover Demonstration Project is a support document to this plan. It provides background on Developing On-site Innovative Technologies (DOIT) Committee and stakeholder participation principles upon which this document is based.

\section{Plan Objective}

The objective of this plan is to integrate stakeholder outreach and participation into the ALCD project. It will establish the major tasks and milestones critical to the integration of stakeholder participation into the implementation of the ALCD.

The plan is intended to provide guidance on the following questions with respect to this demonstration:

- Who are the stakeholders?

- How will they be involved?

- What are the potential areas/issues of concern?

- How and when will their concerns be addressed?

- How will this process be administered?

The goal of effective stakeholder outreach and participation will be value added to the demonstration. the benefits hoped to be realized are:

- building trust and agreement among all stakeholders on this demonstration project;

- creating collaborative and consensual processes and decisions;

- reducing likelihood of conflict and confrontation;

- assuring accountability and responsibility;

- maximizing mutual gain and shared outcomes for all participants; and

- contributing to environmental safety, health, and restoration.

Stakeholder Definition. The term "stakeholder" is defined in the DOIT Stakeholder Outreach and Participation Plan (Discussion Draft, September 1994). Stakeholders 
include a wide range of interested individuals and organizations, but with respect to the ALCD, are not limited to:

- citizens and residents living or working in the vicinity of federal facilities or sites contaminated with hazardous or radioactive wastes, mine wastes, or abandoned munitions;

- local and national public interest and environmental groups;

- elected officials (local, state, national) and Native American Tribal representatives;

- the media (print and electronic);

- representatives of the private sector engaged in environmental waste and restoration activities;

- state and federal agencies;

- educational institutions;

- venture capitalists and insurance companies; and

- labor unions.

\section{Background and Relevance of the Demonstration}

ALCD Project. SNL, in collaboration with other partners, submitted a proposal to the Department of Energy (DOE) to address the technical problems associated with landfill cover failures. In particular, they proposed to test various innovative covers to overcome the problem of "desiccation cracking" in arid/semi-arid environments, a chronic problem indicative of currently accepted technologies. To meet national needs under the Mixed Waste Landfill Integrated Demonstration program, they are required to design, construct, and fully monitor several advanced landfill cover alternatives. The hope is recognition of a preferred cover to "fill a critical void in the state of the art for containment technologies."

The ALCD project will have to meet three performance tests: technical, regulatory, and socio-economic.. The technical performance test will compare three landfill cover designs for ability to meet technical engineering requirements and to be cost effective. The regulatory test is twofold: National Environmental Policy Act (NEPA) approval and Resource Conservation and Recovery Act (RCRA) approval. No use of contaminated land or waste is involved in the demonstration project, but this demonstration, with potential for application of new landfill cover designs at RCRA-regulated land disposal sites, will also enable state and federal regulators early project access. The socioeconomic test touches questions of public health, safety, environmental projection.

The test schedule is for three to five years. During fiscal year 1995, Sandia will begin construction of the first phase. It will consist of three covers: a RCRA Subtitle "C" compacted clay cover with geomembrane; a RCRA Subtitle "D" compacted soil cover; and an alternative geosynthetic clay cover. Two additional alternatives to current RCRA- 
prescribed covers will be constructed in fiscal year 1996: a capillary barrier and a bioengineered barrier. The specific design of the Phase II covers has yet to be determined.

Relevancy. The need for this project reflects the search for a solution to an intractable pollution problem of historic proportions. Since Love Canal, the United States has sought effective remediation programs to address safety, health, and environmental damage at sites contaminated with hazardous, radioactive, and mixed waste materials. Many landfills constructed over the years since Love Canal are leaking; many other sites fail to meet cleanup performance requirements; and solutions for mixed waste are yet to be found.

Significance. The significance of this project lies in a promise that is immediate and long range. In its narrow and formal proportions, the ALCD project is a specific engineering task of regional importance. It is one that will turn on technical and regulatory performance. If the ALCD project proves alternative covers superior in performance and cost, it will help address the problem of desiccation cracking in semi-arid environments.

It also is innovative in its noncontroversial dimension. The demonstration project bears on solid, hazardous, mixed, and radioactive wastes, but it involves the use of a clean site with clean fill. It poses little or no public health and safety risk. Knowledge of this fact will bear on public acceptance and stakeholder involvement. Paradoxically, it probably means the audience for this project is largely a nationwide, professional one rather than local.

In its larger dimension, the ALCD project bears on complex questions of land use, health and safety, acceptable risk, and economic impact that are associated with landfills and has clear implications for the entire nation. The ALCD project promises an innovative solution to the national problem of leaking landfills and national cleanup standards. In this sense, it could help to resolve a protracted national debate over "how clean is clean?" and help move the nation forward in its effort to protect the environment, safety, and health.

In each dimension, the ALCD project sets the stage for a stakeholder involvement plan.

Risk. The use of an uncontaminated site and uncontaminated waste means the public faces little or no significant health or safety risk from the demonstration project. The principal risk associated with the demonstration project is an occupational one. Some onsite environmental risk will occur. With little public risk, the communities most interested in participating in this project are probably professionals and grassroots organizations that are focused on landfills. The goal, however, is to address sites where a risk will exist. Stakeholder involvement will be critical to acceptable of this innovative landfill technology. 


\section{Stakeholder Participation Principles}

In conformity with the above background and the philosophy outlined in the Principles for Stakeholder Participation in the Alternative Landfill Cover Demonstration Project, the ALCD Team (formerly referred to as the Sandia Site Implementation Team) has clear responsibility for the success of a well defined stakeholder participation effort. In the Spring of 1994 efforts were initiated to form the team. Stakeholders were contacted by the DOIT staff the New Mexico Energy, Minerals and Natural Resources Department. Stakeholder groups were briefed on the DOIT program and invited to participate in the implementation team.

A small subset of this audience has become active in the team's activities at this stage. (The mailing list for the team is attached.) The focus, for the most part, has been local. Different members have served in different capacities. Some have contributed to all meetings, others have registered an interest in the project and limited their role to a monitoring one, and many have varied participation in it in different ways. Some have served voluntarily without compensation while others have received compensation. The ALCD Team process to date has incorporated the DOIT operating principle for nomination and representation: an open, continuous process of inclusion with no domination by any group.

\section{Role of ALCD Team:}

- Develop and implement the site implementation and stakeholder outreach plans.

- Interact with the Mixed Waste Working Group.

- Identify and involve stakeholders in the demonstration project and implement the Eight Guiding Principles for Stakeholder participation.

- Realize DOIT goals.

- Win stakeholder support for both DOIT goals and ALCD project.

Role of Stakeholders:

- Contribute to examination, decision, and agreement on project goal, process, results, and schedule.

- Identify stakeholders and establish linkage with Citizen's Specific Advisory Board.

- Ensure public involvement and integration into project.

- Provide responsible feedback, take on tasks, help draft documents, be part of subgroup, contribute to decisions, and ensure input into reviews and evaluation.

- Facilitate communication on mixed waste/DOIT issues. 
Stakeholder Concerns Regarding ALCD Team Landfill Project. Project specific concerns expressed to date include:

1. Identification of regional landfill problems.

2. Innovative models to overcome barriers for landfill technology development and commercialization.

3. Options that address mixed waste DOIT/landfill mission and goals.

4. Public participation and involvement: land use (present use and future) and environmental protection, health and safety, compliance activities and acceptable risks, technology development, cost-benefit and economic impact, and social and equity concerns.

5. Procedural opportunity to review site evaluations and provide feedback that may alter but help to realize demonstration plan.

6. Training and understanding of technical issue.

7. Timely and open communication.

\section{Timeline and Critical Phase Activities of the Stakeholder Outreach Efforts}

The following summarizes the stakeholder outreach and participation activities planned by the ALCD Team.

ACTIVITY

DATE

Distribute Stakeholder Solicitation

Stakeholder Participation Response Forms Returned

Mid-April, 1995

May 1, 1995

Initial Stakeholder Communications (depending on response requests)

Phase I Construction Begins

May/June 1995

Meetings/Tours/Videos of Construction

June 1995

Send Update on Demonstration's Progress

June-August 1995

Phase I Construction Completed

July 1995

Send Phase II Designs Plans for Review by Stakeholders/Regulators

August 1995

Send Update on Demonstration's Progress

October 1995

Receive and Respond to Comments on Phase II Design Plans

October 1995

Initial Construction Cost, Other Results Available (Phase I)

October/November 1995

Send Update on Demonstration's Progress

October/November 1995

Draft Stakeholder Evaluation Survey

December 1995

Begin Evaluation of Enhancements and Demonstration Activities

December 1995

January 1996

In the Spring of 1996, the ALCD Team will begin drafting its report on the demonstration and enhancements, including stakeholder participation to the Mixed Waste Working Group. This report will be open for review and input by stakeholders that participated in the demonstration activities. The report will address stakeholder participation and summarize the evaluation survey of stakeholders. A final report will be submitted to the Mixed Waste Working Group in April or May 1996. 


\section{Elements of ALCD Team Stakeholder Outreach Efforts}

The following identify additional elements of the ALCD Team stakeholder outreach efforts.

\section{Stakeholder Identification}

1. Adequacy Test: ALCD Team determines if stakeholder list meets satisfaction test for quality and quantity of stakeholder representation.

- Who is not represented and how significant is it for support of this project?

- Who is affected - directly and/or indirectly?

- Should there be national representation as well as local?

Timeline: Continuous process of review of baseline list to June 1995.

2. Nomination: Any source, continuous process.

- Search: continuous.

- Process: direct mailing, solicitation, by request.

- Draft solicitation letter and response form.

Timeline: June 1995 \& review at critical events.

3. Publication: publicly announced list of stakeholders participating in process.

Timeline: May-June 1995.

4. Stakeholder Subgroups: Consistent with definition and list above but consider adding.

- Professional landfill community in Western States.

- Local Neighborhood Associations.

- Superfund Coalition and Grassroots groups.

- Stakeholder technical support experts.

Timeline: June 1995 \& before summer construction phase.

Governing Stakeholder Participation Principle

- Consensus principle.

- Roberts Rules of Order, Amended.

- Common understanding on authority and accountability of principal investigators, federal-state agencies, and WGA.

- Ground rules for stakeholder involvement. 
Timeline: Established and reviewed periodically as procedural principle.

Summary \& Overview of Stakeholder Tasks and Procedures for the ALCD Team. Consistent with above tasks and concerns, the team role is to help to:

- Establish critical process components of technical management plan and stakeholder involvement.

- Develop guidance for stakeholder involvement.

- Identify a broad stakeholder pool, solicit participation, and establish expectation goals.

- Provide technical support.

- Incorporate stakeholder planning process in management plan.

- Establish process for consistent, regular communication with and involvement of stakeholders in terms understandable to all. It should include information dissemination process based on mailings/faxes tied closely to critical points in demonstration project.

- Develop monitoring process and data sheets as part of management planning process with information, assessments, and scoring to be shared with stakeholders.

- Provide stakeholders with opportunity to review site evaluations and provide feedback as project unfolds.

- Establish schedule for stakeholder involvement and regular meetings with stakeholders. Compile comments.

- Design evaluation process to lessons learned.

Timeline: Consistent with schedule set above.

\section{Selected Supplemental Checklist}

\section{Stakeholder Database:}

1. Compilation of names, numbers, interests, etc.

2. Inventory of comments, findings, activities, mailings, etc., including expectations.

3. Continuous update of database.

4. Track stakeholder project needs: costs, performance, enabling action, participation, and accountability.

Timeline: May-June 1995 \& periodic upgrade review.

\section{ALCD Team-Stakeholder Interaction/Communication Design}

- Ensure information provided to public is thorough and consistent.

- Ensure responses to requests for information.

- Facilitate communication between stakeholders.

Timeline: May-June 1995 \& periodic upgrade review. 
Administration/Support Staff

- Oversee plan implementation: meeting planning and logistics; record keeping, conduct meetings, distribute agendas, etc.

- Maintenance of database.

- Provide regular updates and reports.

- Provide information.

- Prepare reports.

- Assure communication.

- Provide coordination with Site Specific Advisory Boards.

- Facilitator (if one is needed?).

- Budget preparation.

Timeline: Established \& periodic review for task check.

\section{Centralized Information Access}

- libraries and networks

Timeline: May 1995.

\section{Expertise Requirements and/or Assistance}

- Stakeholder technical support for evaluation of alternative landfill proposals (e.g., technical and regulatory aspects) -- to be provided by the team

Timeline: Review as needed and by request.

\section{Monitoring Provisions}

- Working Group Meeting in Albuquerque -- scheduled to coincide with milestone accomplishments of project implementation.

- Local Stakeholder Meetings -- scheduled as necessary.

- Stakeholder accessibility to video tape planned and prepared for by Principal Investigator.

- Reports and data sheets: funding, environmental effects, worker risk, social cultural, economic impact.

Timeline: April 1995 through April 1996.

\section{Stakeholder Process Products}

- Stakeholder scoping to identify new candidates and review issues of concern.

- Stakeholder guidance on: information and communication needs, preparation and dissemination of informative materials, resources, agenda development, and on schedules and feedback mechanisms, including evaluation process.

- Stakeholder solicitation for participation: receive information only, provide technical review and comment, participate in site tour and/or receive construction video, provide non-technical input.

- Evaluation process for estimating the success of stakeholder participation. It should include development of survey response form based on stakeholder concerns and role described above. In turn, the survey should include estimate of:

1. Numbers and kind of stakeholders who participated in effort; 
2. Sensitivity to stakeholder concerns (land use, environmental protection, safety and health, cost, economic development and commercialization promise as well as procedural issues of public participation and regulation, etc.);

3. Stakeholder comfort with technical issue and national implications ("brownfield use," "how clean is clean"?);

4. Regulatory process, government accountability and anticipated compliance difficulty;

5. Assessment of socio-economic impact of project;

6. Indication of levels of satisfaction and dissatisfaction with the participation and the DOIT process;

7. Remaining outstanding concerns about the demonstration project; and

8. Lessons learned about public participation process, DOIT, technology development, and landfill demonstration project.

Timeline: April 1995. Continuous process of review to Adoption of Final Report by team, April 1996. 
This Page Intentionally Left Blank 
Appendix L

Summary of Responses

Alternative Landfill Cover Demonstrantion

Stakeholder Survey 
This Page Intentionally Left Blank 


\section{SUMMARY OF RESPONSES}

As of May 9:

TOTAL SENT:

TOTAL RETURNED:

YES
1028

192

128

Government (state, local, federal):

$37 / 147$

Industry/Business:

$48 / 271$

Landfill Owners in NM:

$12 / 82$

National Laboratories:

$1 / 9$

Native American (members/reps)

$9 / 26$

Neighborhood Groups:

$5 / 335$

Public Interest Groups:

$7 / 71$

Unions/Labor Groups: $\quad$ 0/4

Universities/Schools $\quad 9 / 44$

Unknown Category $\quad 0 / 6$

New Mexicans: Other States $\quad 95: 33$

NOS 25

Returned to Sender 39

NOT RETURNED: $\quad \mathbf{8 3 6}$

2. Are you interested in participating by (check all that apply):

65 receiving information and updates about the project only

98 reviewing technical documents related to the demonstration

105 participating in a construction site tour and/or receiving construction video.
94. attending meetings or participating in conference calls to discuss specific issues about the demonstration.

Comments: some offered use of their landfill for demonstration site; others just wanted to be part of team or providing technical review (see bold below)

3. What support needs would be required for your participation (check all that apply):

63. none required

22. technical support

53 per diem and mileage reimbursement
Comments: Most indicated that lack of support would limit their participation, particularly travel for out of state stakeholder.

Would you be able to participate if this support was not available? 45 Yes 9 No 
4. What area of the demonstration are you most interested in (check all that apply):

94 regulatory compliance

93 cost of construction

109 performance data

48 commercialization potential
111 technical aspects of the design and implementation of the covers.

48 process of other aspects of the Team's outreach and involvement activities.

Comments: Application to closed sites, msw, superfund sites; ongoing env. mgmt;

5. What are your interests and concerns with regard to landfills and landfill covers? Are there specific landfills about which you are concerns (check all that apply):

71 radioactive and chemical (mixed waste)

83 chemical waste

107 solid wastes

77 release of water

56 bio gas venting

64 intrusion
87 erosion

100 stability

Comments: settlement, locally available and availability of materials; seismic stability; mining wastes; constructability; vegetative support; operation practices; unsaturated flow through covers; long term monitoring; physical characteristics; groundwater; applications to tribal, municipal sw landfills.

6. Please indicate how the demonstration can best meet your interests (check all that apply):

99 summaries of quantitative data results

60 actual data results (hard copies or electronic)

80 overview information
78 video documentation

87 fact sheets

Comments: QA/QC methods, reports; site specific design requirements. 
Appendix M

ALCD Update

Alternative Landfill Cover Demonstration

Answers to Frequently Asked Stakeholder Questions 
This Page Intentionally Left Blank 


\section{Sandia National Laboratories}

Albuquerque, New Mexico 87185-0719

date: November 28, 1995

to: Heidi Snow

from: Steve Dwyer

subject: ALCD Questions

The following are brief replies to some of the stakeholder questions:

1. Q What are the plans for vegetation of the surface cover?

A The covers will all be seeded with the native grass seed mixture. One of the alternative covers that emphasizes evapotransporation will also have plants planted on it.

2. Q How will in-situ hydraulic conductivity be measured?

A $25^{\prime} \times 24^{\prime}$ test pads of the soil barrier layers identical in depth to those constructed in the RCRA Subtitle 'ALCD' Soil Cover (Plot \#1) and RCRA Subtitle 'C' Compacted Clay Cover (Plot \#3) were built. A double ring sealed infiltrometer was placed on each to measure in-situ hydraulic conductivity.

3. $\mathrm{Q}$ How will this demonstration evaluate off-gas from waste and differential settlement problems?

A This demonstration features a water balance study of the test covers. It will not measure the covers ability to handle gas or settlement.

4. $\quad \mathrm{H} \quad$ How will simulated precipitation events be applied?

A A sprinkler system has been installed on the eastern slope of each cover. This system will allow for variability so that many different precipitation events can be simulated on the covers. The western slope of each cover will be evaluated under ambient conditions.

5. Q Will a construction video be available for distribution?

A Video was taken during construction activities. It will be included in an ALCD video to be made once Phase II covers are complete. I can make this tape available to the WGA to make copies for distribution. 
6. Q What is the schedule for anticipated results?

A We will begin collecting and analyzing data ASAP. Tentatively I am planning on an annual release of these results in report form.

7. Q What are the costs for these covers?

A We have been collecting cost information on each cover. Since Phase II has not been built, I don't have a complete set of cost information. I'll put out a report on the construction costs of each cover after compietion of Phase II covers. Phase I covers ranked from highest to lowest as expected: 1) Sub ' $C$ ' Compacted Clay Cover, 2) GCL Cover, 3) Sub 'D' Soil Cover. Cost details will be released in the aforementioned report.

8. Q Will the alternative covers be cost effective?

A Part of the design criteria for the alternative covers required that the alternative cover should be less expensive to construct than the traditional EPA cover.

9. Q What is the evaluation period for these covers?

A We have requested that the covers be monitored actively for 5 years and passively thereafter.

10. Q What are the performance objectives for this demonstration and how do they fit in with DOE work in this area?

A The covers will be installed side-by-side and compared/contrasted based on their respective water balance performance, construction costs, and ease of construction (How easy/practical was it to achieve design specifications). DOE owns more than 3000 landfills. DOE is looking at potentially billions of dollars to cover all of these landfills -- if better and less expensive covers can be achieved, it would be of significant help to DOE and most importantly the US taxpayer.

11. Q Why were traditionally used EPA RCRA sub ' $C$ ' and 'D' covers installed?

A They were installed to be used as baselines to compare the alternative covers with. The traditional EPA covers have been widely criticized as inadequate. We will be able to document the difficulties with these covers and directly compare it with the alternative covers.

Copy to:

J. Nelson

C. Williams

P. Comiskey 


\section{Distribution}

Federal Agencies

3 U.S. Department of Energy Office of Technology Development Attn: J. Paladino, EM-521 Cloverleaf Center 19901 Germantown Rd. Germantown, MD 20874-12901

1 U.S. Department of Energy Albuquerque Operations Office ETN

Attn: Dennis Olona Pennsylvania/H Street Albuquerque, NM 87116

1 U. S. Department of Energy Albuquerque Operations Office DOE AL ETD Attn: J. Lenhert Pennsylvania/H Street Albuquerque, NM 87116

\section{Corporations}

2 Tech Reps, Inc. Attn: Cheryl Allen 5000 Marble NE Albuquerque, NM 87110

\section{Libraries.}

1 Thomas Branigan Library Attn: D. Dresp

$\therefore \quad 106$ W. Hadley St. Las Cruces, NM 88003

1 Government Publications Zimmerman Library University of New Mexico Albuquerque, NM 87131
Internal

\begin{tabular}{llll} 
& \multicolumn{1}{c}{ MS } & & Org \\
1 & 0719 & 6621 & Library \\
& 20719 & 6621 & C.V. Williams \\
2 & 0719 & 6621 & T. Burford \\
1 & 0756 & 6607 & G. Allen \\
5 & 0899 & 4414 & Technical Library \\
1 & 9018 & $8523-2$ & Central Technical Files \\
2 & 0619 & 12630 & $\begin{array}{l}\text { Review \& Approval } \\
\text { Desk for DOE/OSTI }\end{array}$
\end{tabular}


This Page Intentionally Left Blank 